PNL-3513

UC-85

\title{
Investigation of the Condition of Spent Fuel Pool Components
}

September 1981

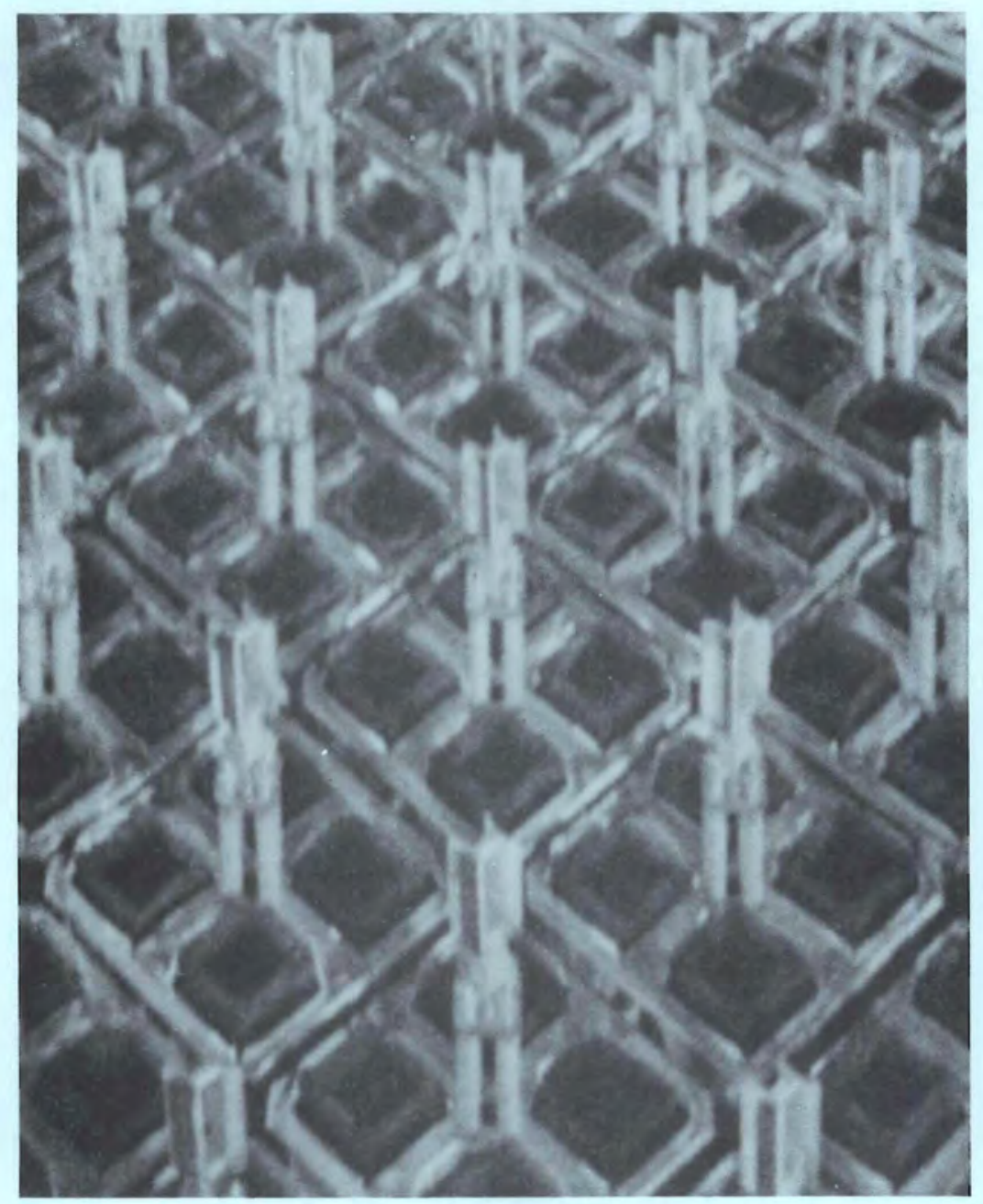

Prepared for the U.S. Department of Energy

Under Contract DE-AC06-76RLO 1830

Pacific Northwest Laboratory

Richland, Washington 99352

\section{*) Battelle}


N O T I C E

This report was prepared as an account of work sponsored by the United States Government. Neither the United States nor the Department of Energy, nor any of their employees, nor any of their contractors, subcontractors, or their employees. makes any warranty, express or implied, or assumes any legal liability or responsibility for the accuracy, completeness or usefulness of any information, apparatus. product or process disclosed, or represents that its use would not infringe privately owned rights.

The views, opinions and conclusions contained in this report are those of the contractor and do not necessarily represent those of the United States Government or the United States Department of Energy.

\author{
PACIFIC NORTHWEST LABORATORY \\ operated by \\ BATTELLE \\ for the \\ UNITED STATES DEPARTMENT OF ENERGY \\ Under Contract DE-AC06-76RLO 1830
}

\author{
Printed in the United States of America \\ Available from \\ National Technical Information Service \\ United States Department of Commerce \\ 5285 Port Royal Road \\ Springfield. Virginia 22151
}

Price: Printed Copy $\$$

$\therefore$ Microfiche $\$ 3.00$

$\begin{array}{cc}\text { •Pages } & \begin{array}{c}\text { NTIS } \\ \text { Selling Price }\end{array} \\ 001-025 & \$ 4.00 \\ 026-050 & \$ 4.50 \\ 051-075 & \$ 5.25 \\ 076-100 & \$ 6.00 \\ 101-125 & \$ 6.50 \\ 126-150 & \$ 7.25 \\ 151-175 & \$ 8.00 \\ 176-200 & \$ 9.00 \\ 201-225 & \$ 9.25 \\ 226-250 & \$ 9.50 \\ 251-275 & \$ 10.75 \\ 276-300 & \$ 11.00\end{array}$


PNL-3513

UC-85

33679000553497

INVESTIGATION OF THE CONDITION OF SPENT FUEL POOL COMPONENTS
F. M. Kustas
S. 0. Bates
B. E. Opitz
A. B. Johnson, Jr.
J. M. Perez, Jr.
R. K. Farnsworth

September 1981

Prepared for the U.S. Department of Energy Under Contract DE-AC06-76RL0 1830

Pacific Northwest Laboratory

Richland, WA 99352 


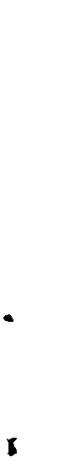




\section{ACKNOWLEDGMENTS}

The authors are grateful to the following facilities for providing specimens for examination: Yankee Atomic Electric Company, Rowe, Massachusetts; Point Beach Nuclear Plant, Two Rivers, Wisconsin; Zion Nuclear Power Station, Zion, Illinois; La Crosse Boiling Water Reactor, Genoa, Wisconsin; the Receiving Basin for Offsite Fuel, Savannah River Plant, Aiken, South Carolina; and Three Mile Island-Unit 1, Goldsboro, Pennsylvania.

The authors would also like to acknowledge R. H. Beauchamp and D. H. Parks of the Materials Department of Pacific Northwest Laboratory for the metallography, and S. K. Edler for her assistance in the preparation of this report.

This study was sponsored by the Division of Transportation and Fue 1 Storage, U.S. Department of Energy. 


\section{ABSTRACT}

It is currently projected that spent nuclear fuel, which is discharged from the reactor and then stored in water pools, may remain in those pools for several decades. Other studies have addressed the expected integrity of the spent fuel during extended water storage; this study assesses the integrity of metallic spent fuel pool components. Results from metallurgical examinations of specimens taken from stainless steel and aluminum components exposed in spent fuel pools are presented. Licensee Event Reports (LERs) relating to problems with spent fuel components were assessed and are summarized to define the types of operational problems that have occurred.

The major conclusions of this study are:

- Aluminum and stainless steel spent fuel pool components have a good history of performance in both deionized and borated water pools.

- Although some operational problems involving pool components have occurred, these problems have had minimal impacts. However, these impacts should be assessed by spent fuel pool designers and operators to minimize similar problems in the future. 


\section{SUMMARY}

There is an emerging recognition that spent fuel may remain in water pools for several decades until a decision regarding its final disposition is ratified and implemented.

In spent fuel pool (SFP) licensing hearings, hearing boards frequently request information regarding the condition of materials in the pools. In addition, numerous new SFPs and replacement components for existing pools are being planned. The investigations described in this report were conducted by Pacific Northwest Laboratory (PNL) to provide information on materials behavior during exposures in SFPs.

The sources of information summarized in this report include:

- SFP materials behavior problems based on operator reports to the U.S. Nuclear Regulatory Commission. (NRC)

- observations from surveys and discussions with SFP operators

- results of metallurgical investigations on specimens that were exposed in SFPs.

The principal materials in SFP components are aluminum alloys--for fuel storage racks--and stainless steel (SS)--for storage racks, liners, and piping. There are two types of SFP chemistries:

- pressurized water reactor (PWR) pools having boric acid chemistry (0.02- $\mathrm{M} \mathrm{H}_{2} \mathrm{BO}_{3}$ including 2000-ppm B); the boric acid is used to match the composition of the $\mathrm{H}_{3} \mathrm{BO}_{3}$ in the reactor primary system during refueling

- boiling water reactor (BWR) and away-from-reactor (AFR) pools using deionized water.

The principal problems mentioned in event reports involved pump seal failures and hose disconnections, minor leaks in SFP pipes and liners, minor fuel assembly damage during handling, air overpressurization damage during attempted cleaning of pool liner channels, piping and weld defects during fabrication, pipe breakage due to freezing during power outages, and corrosion-induced 
events in SFP piping (see Appendix A for a more complete listing). Although these problems are minimal, they deserve the attention of storage pool designers, fabricators, and operators.

The scope of PNL examinations of SFP components is summarized in Table 1. Investigation of stainless steel SFP component specimens indicated that uniform corrosion was so small that it was not detectable by metallographic techniques $(<\sim 5 \mu \mathrm{m}$ after up to $15 \mathrm{yr})$. Mild $(25-$ to $75-\mu \mathrm{m})$ intergranular corrosion was observed in the heat-affected zones near two welds on one SS component. In one investigation an intergranular crack had propagated through the wall of a 20-cm (8-in.) diameter pipe from a backup (stagnant) SFP heat transport system. The aluminum component examined had an oxide layer of less than $8 \mu \mathrm{m}$ and some very minor pitting $(<10 \mu \mathrm{m})$.

A systematic laboratory study is underway at PNL to investigate the effects of various SFP environments on materials behavior. This study will provide additional insights to materials behavior and to approaches to minimize impacts of materials problems on SFP operation. Discussions with pool operators also reflected that pool operations are generally mundane and free of serious problems. 
TABLE 1. Summary of Spent Fuel Component Examination

\begin{tabular}{|c|c|c|c|c|c|c|}
\hline Pool & $\begin{array}{l}\text { Reactor } \\
\text { Type } \\
\end{array}$ & $\begin{array}{r}\text { Years } \\
\text { in Pool } \\
\end{array}$ & Material & $\begin{array}{l}\text { Number } \\
\text { of Welds } \\
\text { Visually } \\
\text { Examined } \\
\text { at PNL } \\
\end{array}$ & Visual & $\begin{array}{l}\text { Observation } \\
\text { Metallographic }\end{array}$ \\
\hline Yankee Rowe & PWR & 1.4 & $30 \mathrm{S5}$ & 8 & $\begin{array}{l}\text { Heat tinting and spatter near welds } \\
\text { suggesting high welding temperature; } \\
\text { structurally sound; no pits or } \\
\text { cracks. }\end{array}$ & $\begin{array}{l}4 \text { welds examined: mild intergranu- } \\
\text { lar attack in } 2 \text { of } 4 \text { heat-affected } \\
\text { zones. Maximum attack }-75 \text { um. }\end{array}$ \\
\hline Point Beach & PWR & 6.7 & 304 SS & 4 & $\begin{array}{l}\text { Untarnished finish; some heat tint- } \\
\text { ing near welds; structurally sound } \\
\text { with no pits or cracks. }\end{array}$ & $\begin{array}{l}4 \text { welds examined: no evidence of } \\
\text { intergranular attack or degrada- } \\
\text { tion. }\end{array}$ \\
\hline Zion & PWR & 4.8 & 304 SS & 17 & $\begin{array}{l}\text { Structurally sound; no pits or } \\
\text { cracks; untarnished finish with } \\
\text { some heat tinting near welds. }\end{array}$ & $\begin{array}{l}7 \text { welds and } 1 \text { piece examined: a } \\
\text { small amount of crevice pit corro- } \\
\text { sion (<15 um); no other signifi- } \\
\text { cant attack. }\end{array}$ \\
\hline LACBNR & BWR & $\begin{array}{l}11.5 \\
3.5\end{array}$ & $\begin{array}{l}304 \text { SS } \\
\text { Bor al }\end{array}$ & 36 & $\begin{array}{l}\text { Untarnished finish: heat tinting } \\
\text { near welds; structurally sound } \\
\text { with no pits or cracks. }\end{array}$ & $\begin{array}{l}4 \text { weids examined: no evidence of } \\
\text { intergranular attack or degrada- } \\
\text { tion. Boral showed } 6 \text {-um oxide } \\
\text { layer. }\end{array}$ \\
\hline RBOF & AFR & $\begin{array}{l}15 \\
16\end{array}$ & $\begin{array}{l}304 \mathrm{SS} \\
6061 \mathrm{Al}\end{array}$ & 14 & $\begin{array}{l}\text { Untarnished bright finish: some } \\
\text { heat tinting near welds: structur- } \\
\text { ally sound. Aluminum showed dull } \\
\text { tarnished finish. }\end{array}$ & $\begin{array}{l}2 \text { welds and } 1 \text { piece examined; no } \\
\text { significant intergranular attack } \\
\text { or corrosion. Aluminum components } \\
\text { had an oxide layer of } 8 \text { um and } \\
\text { minor pitting }(<10 \mathrm{um}) \text {. }\end{array}$ \\
\hline
\end{tabular}


$\bullet$ 


\section{CONTENTS}

ACKNOWLEDGMENTS

ABSTRACT

SUMMARY

INTR ODUCTION

SPENT FUEL POOL MATERIALS AND ENVIRONMENTS

SPENT FUEL POOL MATERIALS

NORMAL SPENT FUEL POOL ENVIRONMENTS

UNUSUAL SPENT FUEL POOL CHEMISTRIES

SFP CONFIGURATIONS AND COMPONENTS

SPENT FUEL POOL COMPONENT EXPERIENCE

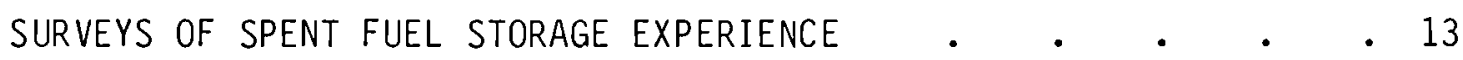

INSIGHTS TO SPENT FUEL POOL COMPONENT BEHAVIOR FROM

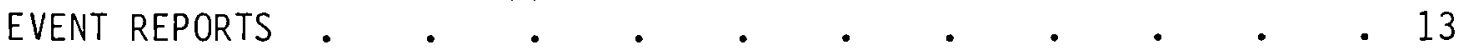

BEHAVIOR OF ALUMINUM SPENT FUEL POOL COMPONENTS $\quad$ • . $\quad$ • 14

EXAMINATION OF A YANKEE ROWE (PWR) STAINLESS STEEL SPENT FUEL POOL

RACK SUPPORT SECTION

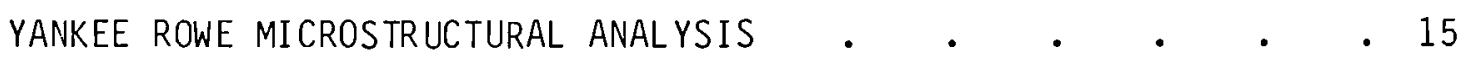

YANKEE ROWE WELDING THERMAL HISTORY . • • • • . • 23

DISCUSSION OF YANKEE ROWE SPENT FUEL POOL RACK SECTION • • • 23

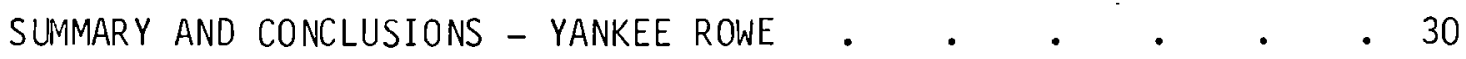

EXAMINATION OF A POINT BEACH (PWR) SPENT FUEL STORAGE RACK SECTION • 31

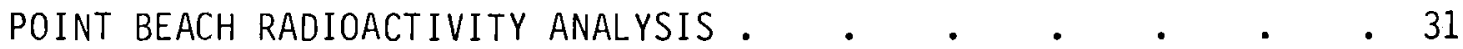

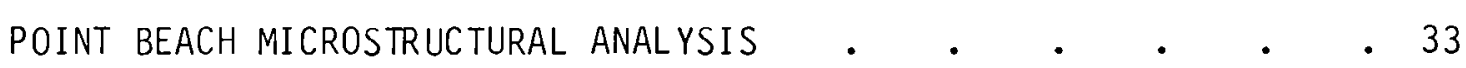

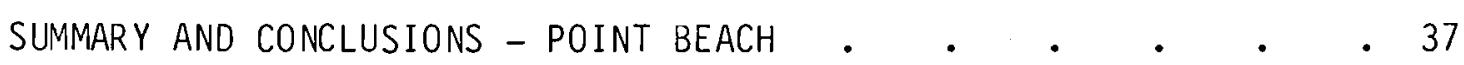

EXAMINATION OF ZION (PWR) SPENT FUEL POOL RACK SECTIONS $\quad • \quad$ • $\quad 45$ 


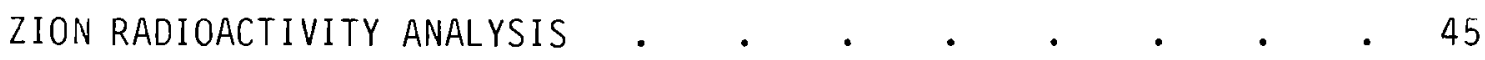

ZION MICROSTRUCTURAL ANALYSIS •

SUMMARY AND CONCLUSIONS - ZION

EXAMINATION OF LA CROSSE (BWR) SPENT FUEL STORAGE RACK SECTIONS • $\quad 53$

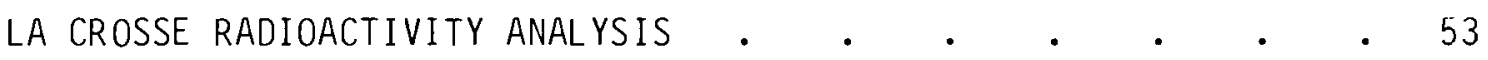

LA CROSSE METALLOGRAPHIC ANALYSIS . . . . . . . . . 55

SUMMARY AND CONCLUSIONS - LA CROSSE

EXAMINATION OF RBOF STAINLESS STEEL AND ALUMINUM COMPONENTS • • $\quad 63$

RBOF METALLOGRAPHIC ANALYSIS $\cdot$ •

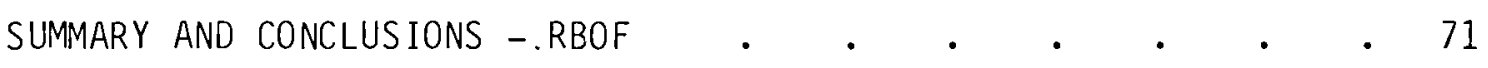

THREE MILE ISLAND (TMI) PIPE EXAMINATION $\cdot \cdot \cdots$

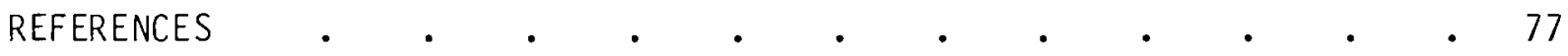

APPENDIX A - INCIDENT REPORTS . . . . . . . . . . . . . A.1

APPENDIX B - FABRICATION PARAMETERS FOR STAINLESS STEEL SPENT FUEL POOL COMPONENTS •

APPENDIX C - WELDING THERMAL ANALYSIS . . . . . . . . . C.1 


\section{FIGURES}

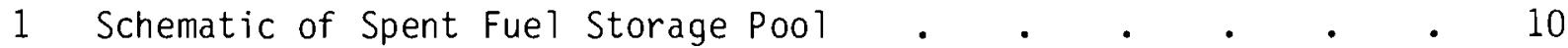

2 Sequential Views of First-Generation Point Beach (PWR) Spent Fuel Storage Rack Being Removed from the Borated Water Pool . . 11

3 Schematic of Top View of Yankee Rowe Spent Fuel Pool • • • 16

4 Metallographic Examination of a Yankee Rowe (PWR) Spent Fuel

Pool Rack Support Section . . . . . . . . . 18

5 Metallographic Examination of Yankee Rowe Vertical Plate and

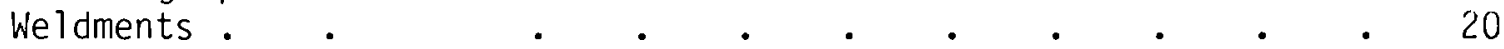

6 Metallographic Examination of Yankee Rowe Left Weldment $\quad$ - $\quad 21$

7 Metallographic Examination of Yankee Rowe Right Weldment and

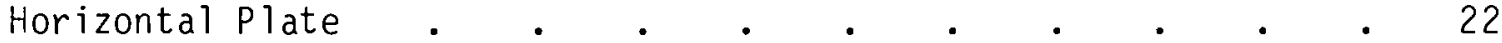

8 Schematic of Yankee Rowe Weldments Showing Microstructural Zones . 23

9 Peak Temperature Versus Distance from Weld Fusion Line . $\quad$ • 25

10 Peak Temperature Versus Distance from Fusion Line . • • • 26

11 Possible Mechanisms for Intergranular Attack on Welded Austenitic Stainless Steels . . . . . . . . . 27

12 Intergranular Corrosion of 304 SS Tested in Acid Copper

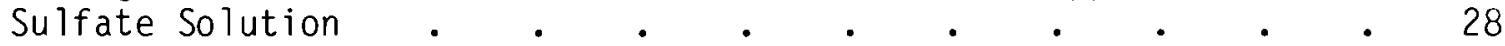

13 Plan View of Spent Fuel Storage Racks in Point Beach (PWR) Pool . 32

14 Plan and Elevation Views of Point Beach Fuel Storage Rack from Which Specimen Was Taken • • • • • • • • • .

15 Type 304 SS Spent Fuel Pool Rack After $6.7 \mathrm{yr}$ in Point Beach (PWR) Pool $. \quad . \quad . \quad . \quad . \quad . \quad . \quad . \quad 34$

16 Views of Rack Section, Nut, and Washer from Point Beach Rack $\quad 35$

17 Radioactivity Distribution of Point Beach Rack Section . . . 38

18 Radioactivity Distribution of Point Beach Nut and Washer . $\quad 39$

19 Fuel Storage Rack from Point Beach (PWR) Spent Fuel Pool • • 40

20 Metallographic Examination of Point Beach Fuel Storage Rack Specimen PB2 
21 Metallographic Examination of Point Beach Fuel Rack Nut . $\quad 42$

22 Metallographic Examination of Point Beach 304 SS Fuel

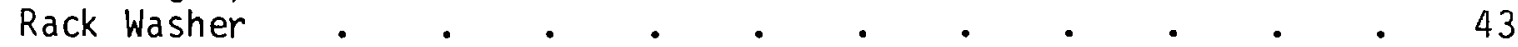

23 Zion Spent Fuel Pool Arrangement . . . . . . . . . . 46

24 Fuel Storage Rack Section from Zion (PWR) Spent Fuel Pool • • 47

25 Inside of Fuel Storage Rack Section from Zion (PWR)

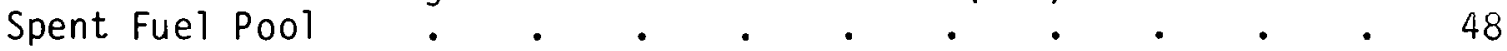

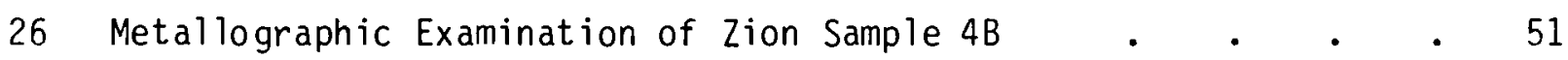

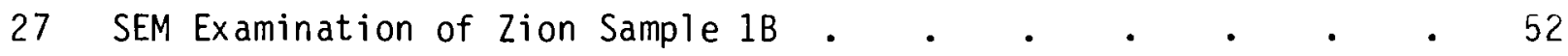

28 La Crosse (BWR) Fuel Storage Rack Specimen L4C . $\quad$ • . $\quad$ • 57

29 Metallographic Examination of La Crosse (BWR) Fuel Storage Rack

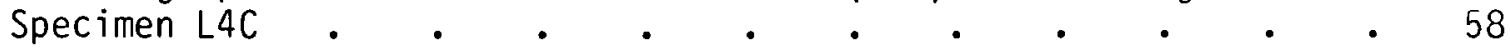

30 La Crosse Boral Plate Cross Section - Specimen L9 . . . . 59

31 Metallographic Examination of La Crosse Boral Plate Cross

32 Two Views of La Crosse (BWR) Fuel Storage Rack Specimen L10 • • 61

Metallographic Examination of La Crosse (BWR) Fuel Storage Rack
Specimen L10

34 Roller Table Section from Receiving Basin for Offsite
Fuels (RBOF), Savannah River Plant . $\quad$ • $\quad$ • $\quad$ • . 64

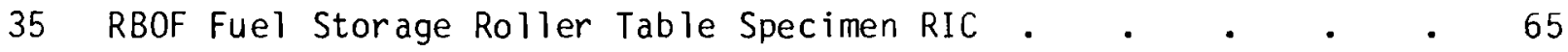

36 Front and Back Views of RBOF Aluminum Fuel Rack Spacer . • . 66

37 Metallographic Examination of RBOF Fuel Storage Roller Table

38 Metallographic Examination of RBOF Fuel Storage Roller
Table Ruler Specimen R3B
.

39 Oxide Layers on RBOF Aluminum Fuel Rack Spacer . $\quad$. . . . 69

\begin{tabular}{l}
40 Metallographic Examination of RBOF Aluminum Fuel Rack \\
Spacer Alloy 6061-T6 \\
\hline
\end{tabular} 
41 Section of Three Mile Island-Unit 1304 SS Pipe from a Stagnant Leg of the Spent Fuel Pool Heat Transport System • • • 75

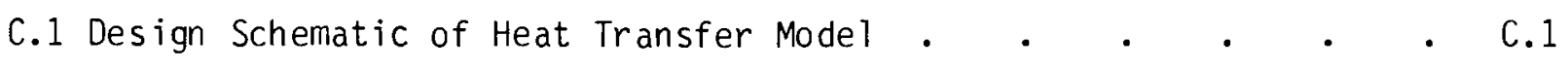




\section{TABLES}

1 Summary of Spent Fuel Component Examination . • • • • • $\quad$ ix

2 Summary of Materials in Spent Fuel Pools . . . . . . . 4

3 Examples of Aluminum Alloy Fuel Racks in Spent Fuel Pools . $\quad 5$

4 Spent Fuel Pool Water Quality Specifications . . . . . . 6

5 Water Composition in Fuel Receiving and Storage Facility

Spent Fuel Pool at INEL .

6 Analysis of TAN Fuel Storage Canal Water After

$12 \mathrm{yr}$ with No Purification . . . . . . . . . . . 9

7 Rack Support Specimen Compositions and Pool Conditions for

Yankee Rowe Spent Fuel 304 SS Rack Support . . . • . 17

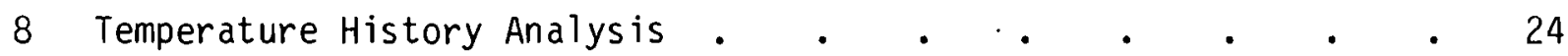

9 Rack Specimen Compositions and Pool Conditions for Point

Beach Spent Fuel 304 SS Rack . . . . . . . . 36

10 Concentration Ranges for Radioactive Isotopes in Point Beach

11 Rack Specimen Compositions and Pool Conditions for Zion

12 Rack Specimen Compositions and Pool Conditions for
La Crosse Spent Fuel Storage Rack

13 Concentration Ranges for Radioactive Isotopes in La Crosse
(BWR) Spent Fuel Pool Water . . . . . . . . . 55

14 Radioactivity Measured on Surfaces of La Crosse Spent Fuel Storage Rack Specimens in Early 1981 .

B.1 Chemical Requirements for Type 304 Stainless Steel $\quad$ - • • B.1

C.1 Thermophysical Properties for Type 304 Stainless Steel • • • C.5 


\section{INTRODUCTION}

Spent fuel pools (SFPs) have provided an important link in nuclear fuel management since the first nuclear reactors began to discharge fuel $35 \mathrm{yr}$ ago. Since then, the technology for spent fuel handling and storage has undergone some advances, such as:

- installation of stainless steel (SS) liners for the reinforced concrete structure

- use of ion exchange, filtration, skimmers, and vacuum cleaners to maintain water purity and to control levels of radioactive species in the water

- use of heat exchangers to control pool water temperatures

- use of neutron absorbers such as boron to permit closer packing of fuel assemblies

- use of advanced devices to improve fuel handling.

Compared to many technologies, there have been relatively few materials problems in SFP technology. Temperatures are low; water chemistries are relatively benign; and there is minimal need for equipment with moving parts. However, any technology is subject to some types of materials problems. A cross section of cases involving materials or equipment malfunctions in modern SFPs is summarized in Appendix $A$ and is based on event reports to the U.S. Nuclear Regulatory Commission (NRC).

Currently, interim storage of spent fuel in water pools for several decades appears likely. Licensing boards for SFP modifications frequently request information regarding materials behavior. In response to these needs Pacific Northwest Laboratory (PNL), (a) under a U.S. Department of Energy (DOE) contract, developed an assessment of SFP component behavior from the following sources:

(a) Operated for DOE by Battelle Memorial Institute. 
- a prior survey of SFP experience(1)

- NRC incident reports (Appendix A) summarizing a cross section of SFP component malfunctions

- metallurgical examination of specimens from components retired from SFPs.

This assessment provides a current perspective of materials behavior in SFPs. The Spent Fuel and Fuel Pool Component Integrity Program at PNL will continue to focus principally on fuel cladding integrity but will also include evaluation of fuel pool component materials. (2)

The remainder of this report consists of a discussion of SFP materials and environments and the results of examinations done on SFP components from Yankee Rowe, Point Beach, Zion, La Crosse, and the Receiving Basin for Offsite Fuel (RBOF). The examination of a section of a Three Mile Island-Unit 1 pipe with a through-wall defect is also summarized. 
SPENT FUEL POOL MATERIALS AND ENVIRONMENTS

SPENT FUEL POOL MATERIALS

It is evident from Table 2 that stainless steel is the material most frequently used for SFP components such as liners for the concrete pool, storage racks, canisters, piping, and heat exchangers. The longest continuous exposure of SS fuel pool components to water occurred at the $X-10$ reactor pool (0ak Ridge National Laboratory), which first stored fuel in November 1943 and is still storing radioactive materials (1981). The longest exposure of SS spent fuel pool components to borated water appears to have occurred at the Indian Point 1 reactor, which began operation in 1962 and is continuing to store fuel in 1981 .

Aluminum has been used as a rack and canister material principally in deionized water pools; however, aluminum racks have also been installed in a few pressurized water reactor (PWR) pools (see Table 3 ).

NORMAL SPENT FUEL POOL ENVIRONMENTS

The two principal SFP environments are summarized in Table 4: boiling water reactor (BWR) or away-from-reactor (AFR) pools, which use deionized water; and PWR pools, which use boric acid chemistries.

The PWR primary coolant includes boric acid as a chemical shim for fuel reactivity control. Most PWR pools use equal boric acid concentrations in the primary coolant and in SFP waters. The boric acid provides a measure of reactivity control in the pool; however, no credit is taken for this aspect in the design of PWR pool racks. The principal justification for use of boric acid in the SFP is to provide compatibility with the primary coolant during refueling.

Some PWRs do not use the full boric acid concentration as indicated below.

- The Shippingport (Pennsylvania) reactor is listed as a PWR although it is not of standard PWR design. The primary system chemistry uses ammonia, and the SFP chemistry is deionized water.

- The Yankee Rowe (Massachusetts) reactor is an early-vintage (1961) PWR. The primary system utilizes boric acid as a chemical shim for 
TABLE 2. Summary of Materials in Spent Fuel Pools(a)

\begin{tabular}{|c|c|c|c|}
\hline Component & Subcomponents & Material (b) & Alloy \\
\hline Wa 11 & $\ldots$ & Re infurced Cuncrete & - \\
\hline Pool Liner & -- & $\begin{array}{l}\text { Stainless Steel } \\
\text { Epoxy, Filuerglass }\end{array}$ & 304 \\
\hline Heat Exchanger (c) & -- & Stainless Steel & $304 / 316$ \\
\hline Filter & $\begin{array}{l}\text { vessel } \\
\text { Filter Elements }\end{array}$ & $\begin{array}{l}\text { Stainless Steel } \\
\text { Stainiless Steel } \\
\text { Uiatom, Earth, Fiber }\end{array}$ & $\begin{array}{l}304 \mathrm{~L} \\
304 \mathrm{~L}\end{array}$ \\
\hline Recirculating Pumps & $\begin{array}{l}\text { Casing, Shatt } \\
\text { Impeller }\end{array}$ & $\begin{array}{l}\text { Stainless Steel } \\
\text { Bronze }\end{array}$ & 316 \\
\hline $\begin{array}{l}\text { Demineralized Water } \\
\text { Return Pump }\end{array}$ & Casing, lmpeller, Shaft & Stainless Steel & 316 \\
\hline De ionization Urit & Tank & Stainless Stetel & $304 \mathrm{~L}$ \\
\hline Cask Head Support Racks & -- & Stainiess Steel & $304 \mathrm{~L}$ \\
\hline Gates and Guices & - & Stainless Steel & $304 \mathrm{~L}$ \\
\hline \multirow[t]{2}{*}{ Fuel Storage Racks(d) } & Racks & $\begin{array}{l}\text { Stafnless Steel } \\
\text { Aluminum }\end{array}$ & $\begin{array}{l}\text { 3U4L } \\
\text { 6061-T6 }\end{array}$ \\
\hline & $\begin{array}{l}\text { Embedded Supports } \\
\text { Reutron ALsorber }\end{array}$ & $\begin{array}{l}\text { Stainiess Steel } \\
\text { Aluminum- } B_{4} C \\
\text { Composite }\end{array}$ & $\begin{array}{l}304 L \\
\text { Boral }\end{array}$ \\
\hline Fuel Storage Canisters(d) & -. & $\begin{array}{l}\text { Stainless Steel } \\
\text { Aluminum }\end{array}$ & $\begin{array}{l}3 \cup 4 L \\
5083 / 5086 / 6063\end{array}$ \\
\hline Leaker Can Support Racks & -- & $\begin{array}{l}\text { Stainless Steel } \\
\text { Carbon Steel, } \\
\text { Epoxy Coated }\end{array}$ & -- \\
\hline $\begin{array}{l}\text { Control Rod Cluster } \\
\text { Storage Racks }\end{array}$ & -- & Stainless Steel & - \\
\hline Portable Off-Gas Hoous & -- & $\begin{array}{l}\text { Stainless Steel } \\
\text { Aluminum }\end{array}$ & -- \\
\hline Cask Handling Crane & Cable and Grapple & Stainless Steel & -- \\
\hline Canister Crane & Lable and lirapple & Stainless Steel & -- \\
\hline Fuel Trarisfer Conveyer & -- & Stainiess Steel & $304 \mathrm{~L}$ \\
\hline Insulators & -- & Tygun, Neoprene & \\
\hline \multirow[t]{2}{*}{ Cask Impact Pad } & $\begin{array}{l}\text { Cladding } \\
\text { Pad (not exposed } \\
\left.\text { to } \mathrm{H}_{2} \mathrm{O}\right)\end{array}$ & $\begin{array}{l}\text { Stainless steel } \\
\text { Carbon Steel } \\
\text { (3-1/2 in. thick) }\end{array}$ & \\
\hline & $\begin{array}{l}\text { Honeycomb (not exposed } \\
\text { to } \mathrm{H}_{2} \mathrm{O} \text { ) }\end{array}$ & Aluminum & \\
\hline
\end{tabular}

(a) Reference 1 .

(b) Types identified in survey; other types may be useo in sone pools.

(c) Carbon steel tubes were originally installed in heat exchangers at one pool; severe rusting caused a visibility probiem in the pool water, resulting in retubing with stainless steel. Copper alloy tubes are used at one R\&D facility.

(d) Some canister and rack walls contain boron-impregnated aluniinum for reactivity control; the boron-containing naterials are clad with stainless steel or aluminum. 
TABLE 3. Examples of Aluminum Alloy Fuel Racks in Spent Fuel Pools

$\frac{\text { Spent Fuel Pool }}{\text { Studsvik }}$

G. E.-Morris

WAK

Yankee Rowe

Three Mile IslandUn it 1

Maine Yankee

Oyster Creek

NFS

NRX

RBOF

FRSF (e)

\section{$\frac{\text { Location }}{\text { Studsvik, Sweden }}$ \\ Morris, IL, USA \\ Karlsruhe, GFR \\ Rowe, MA, USA}

Goldsboro, PA, USA

Wiscasset, ME, USA

Toms River, NJ, USA

West Valley, NY, USA

Chalk River, Ontario, Canada

Savannah River, SC, USA

Idaho Falls, 10, USA

\begin{tabular}{|c|c|}
\hline Pool Chemistry & Time in Pool \\
\hline Deionized Water & 1964 to present \\
\hline Deionized Water & 1972 to 1976 \\
\hline Deionized Water & 1969 to present (b) \\
\hline Boric Acid(c) & $17 \mathrm{yr}$; maximium \\
\hline Boric Acid & 1974 to present \\
\hline Boric Acid & 1977 to present \\
\hline Ueionizeo water & $7 \mathrm{yr}(\mathrm{d})$ \\
\hline Deionized Water & 1965 to present \\
\hline Deionized Water & 1959 to present \\
\hline Deionized water & 1963 to present \\
\hline$(f)$ & 1903 to present \\
\hline
\end{tabular}

\author{
No problems. \\ Corrosion at poor welds. (a) \\ No corrosion after anodizing. \\ Small anount of pitting; \\ good structural integrity. \\ No problems; insulated \\ from SS liner. \\ No problems. \\ No prublems. \\ No problems. \\ No problems. \\ No problems. \\ pitting corrosion.
}

(a) Most welds were uncorroded; only poorly made welos corroded.

(b) In 1973 one-half of the aluminum racks were replaced with stainless steel ones.

(c) $800-p$ pm B maximum.

(d) Examination of locations on aluminum racks where they contactes SS pool liner revealeu no signiticant crevice corrosion.

(e) Operated by Idaho National Engineering Laboratory (INEL).

(f) Up to 730-ppm Cl- and 590-ppm NO3; currently Cl- $=360 \mathrm{ppm}$ and $\mathrm{NU}_{3}=430 \mathrm{ppm}$. 
TABLE 4. Spent Fuel Pool Water Quality Specifications(a)

\begin{tabular}{|c|c|c|c|}
\hline \multirow{2}{*}{ Parameter } & \multicolumn{2}{|c|}{ PWR } & \multirow[b]{2}{*}{ BWR/AFR } \\
\hline & Normal & $\begin{array}{l}\text { Transient } \\
\text { Limits } \\
\end{array}$ & \\
\hline $\mathrm{pH}\left(77^{\circ} \mathrm{C}\right)$ & 4.5 to $6.0(\mathrm{~b})$ & -- & 5.3 to 7.5 \\
\hline $\begin{array}{l}\text { Conductivity at } 25^{\circ} \mathrm{C} \text {, } \\
\text { umho/cm }\end{array}$ & 1 to 30 & -- & $3(c)$ \\
\hline $\begin{array}{l}\text { Chloride Ion, } \\
\mathrm{ppm}(\max )\end{array}$ & 0.15 & 1.5 & 0.5 \\
\hline $\begin{array}{l}\text { Fluoride Ion, } \\
\text { ppm (max) }\end{array}$ & 0.1 & 1.5 & -- \\
\hline Oxygen & Saturated & Saturated & -- \\
\hline $\begin{array}{l}\text { Total Suspended } \\
\text { Solids, ppm (max) }\end{array}$ & 1.0 & -- & -- \\
\hline Temperature, ${ }^{\circ} \mathrm{C}$ & 50 & 100 & -- \\
\hline $\begin{array}{l}\text { Boric Acid, } \\
\text { ppm B(d) }\end{array}$ & $\begin{array}{l}0 \text { to } 2000 \\
1950 \text { to } 2250\end{array}$ & $\begin{array}{l}-- \\
--\end{array}$ & $\begin{array}{l}-- \\
--\end{array}$ \\
\hline $\begin{array}{l}\text { Activity Level, } \\
\mu \mathrm{Ci} / \mathrm{ml}\end{array}$ & $\begin{array}{l}0.05 \\
\text { varies with } \\
\text { tech spec. }\end{array}$ & & \\
\hline $\begin{array}{l}\text { Solid Filtration, } \\
\text { microns }\end{array}$ & 1 to 5 & & \\
\hline
\end{tabular}

(a) May vary somewhat from pool to pool.

(b) Some fuel pool pH specifications range from 4.5 to 8.0; a few pools range from 7.0 to 10.6 .

(c) 1.5 at some pools.

(d) Some PWR fuel pool specifications also indicate a lithium concentration range from 0.2 to $2.0 \mathrm{ppm}$, corresponding to values for PWR primary systems. 
fine adjustments to fuel reactivity. The SFP started with a deionized water chemistry, and boric acid is added to the pool only when the borated primary system water is mixed with the pool water. Thus, boric acid concentrations in the Yankee Rowe SFP have been lower than in other PWR spent fuel pools, where boron concentrations are typically controlled at $>2000-p p m$ B by intentional additions of boric acid. By January 1979 the boric acid concentration in the Yankee Rowe pool had risen to 800-ppm B compared to typical concentrations of 2000-ppm B in other PWR pools.

\section{UNUSUAL SPENT FUEL POOL CHEMISTRIES}

A few SFPs have operated with chemistries that depart from the norms indicated in the preceding section. The most notable example is the Fuel Receiving and Storage Facility (FRSF) pool at the Idaho National Engineering Laboratory (INEL), Idaho Falls, Idaho.

Due to problems with algae growth, the pool received heavy chlorine dosing, which resulted in the impurity levels indicated in Table 5 . Improvements in controlling biological species at the pool included installation of a side stream ultraviolet light treatment; and in 1976 a scraped surface evaporator and a reverse osmosis system were added to the pool, resulting in the water chemistry improvements shown in Table 5. The high chloride levels in the pool resulted in obvious corrosion to aluminum pool components. However, SS components and SS- and Zircaloy-clad fuel resided in the pool for several years with no obvious problems.

The question sometimes arises: What would happen to the pool chemistry if a pool were left for an extended period without purification? An opportunity arose to make a relevant observation at the Test Area North (TAN) facility at INEL. The SFP was deactivated in approximately 1967, and until that time water purity had been maintained by ion exchange and filtration. The pool is housed inside a cinder block building and during windstorms airborne dust enters the building; therefore, the pool environment is not totally isolated from the desert terrain. The pool water was sampled in 1979 (see 
TABLE 5. Water Composition in Fuel Receiving and Storage Facility Spent Fuel Pool at $\operatorname{INEL}(a)$

\begin{tabular}{lcc} 
Component & $\begin{array}{c}\text { Content } \\
\text { Before CRS (b) } \\
\text { Operation, } \\
\mu \mathrm{g} / \mathrm{ml}\end{array}$ & $\begin{array}{c}\text { Content } \\
\text { After CRS } \\
\text { Operation, } \\
\mu \mathrm{g} / \mathrm{ml}\end{array}$ \\
\cline { 2 - 3 } $\mathrm{Cl}$ & 730 & 360 \\
$\mathrm{Na}$ & 715 & 415 \\
$\mathrm{NO}_{3}$ & 590 & 430 \\
$\mathrm{Ca}$ & 18 & 4.2 \\
$\mathrm{SO}_{4}$ & 53 & 30 \\
$\mathrm{Si}^{2}$ & 3.4 & 3.5 \\
$\mathrm{Mg}$ & 2.6 & 1.4 \\
$\mathrm{HCO}_{3}$ & 59 & 52 \\
$\mathrm{TDS}^{(\mathrm{C})}$ & 2250 & 1320
\end{tabular}

(a) McClure, L. W. 1977. "Chloride Removal from Storage Basin Waters." American Nuclear Society Trans. 27:487.

(b) $\overline{C R S}=$ chloride removaT system.

(c) TDS = total dissolved solids.

Table 6). Perhaps most significant is the chloride content of the pool water, which had risen to only $1.8 \mathrm{ppm}$ after $12 \mathrm{yr}$ with no purification.

SFP CONF IGURAT IONS AND COMPONENTS

Figure 1 shows a cross section of a SFP, indicating the schematic configuration and the major components. Figure 2 shows two views of a spent fuel storage rack as it was removed from a PWR pool after $6.7 \mathrm{yr}$ of storage. 
TABLE 6. Analys is of TAN Fuel Storage Canal Water(a) After 12 yr with No Purification

\begin{tabular}{|c|c|c|c|}
\hline $\begin{array}{l}\text { Chemical } \\
\text { Species } \\
\end{array}$ & $\begin{array}{c}\text { Concentration, } \\
\text { ppm wt }\end{array}$ & $\begin{array}{l}\text { Radioactive } \\
\text { Species } \\
\end{array}$ & $\begin{array}{c}\text { Concentration, } \\
\mathrm{dps} / \mathrm{ml}\end{array}$ \\
\hline $\mathrm{Al}^{-}$ & 0.18 & ${ }^{137} \mathrm{Cs}$ & 32.6 \\
\hline B & 0.12 & ${ }^{134} \mathrm{Cs}$ & 6.45 \\
\hline $\mathrm{Ca}$ & 1.8 & ${ }^{60} \mathrm{Co}$ & $5 \times 10^{-2}$ \\
\hline $\mathrm{Cu}$ & 0.021 & ${ }^{90} \mathrm{Sr}$ & $4 \times 10^{-1}$ \\
\hline $\mathrm{Mg}$ & 0.003 & & \\
\hline $\mathrm{Na}(b)$ & 7.4 & & \\
\hline $\mathrm{Ni}$ & 0.0066 & & \\
\hline$S i(c)$ & 4.1 & & \\
\hline$k^{(b)}$ & 5.4 & & \\
\hline $\mathrm{Hg}$ & $<2 \times 10^{-5}$ & & \\
\hline $\mathrm{Cl}^{-}$ & 1.8 & & \\
\hline $\mathrm{F}^{-}$ & 0.4 & & \\
\hline
\end{tabular}

(a) Canal water volume $=2,649,000$ \& $(700,000$ gal); estimated dissolved solids $=50$ to $100 \mathrm{~kg}$.

(b) $\mathrm{K}$ and $\mathrm{Na}$ may be from NaK (from fast reactor fuel stored in the canal).

(c) Probably from airborne particulates. 


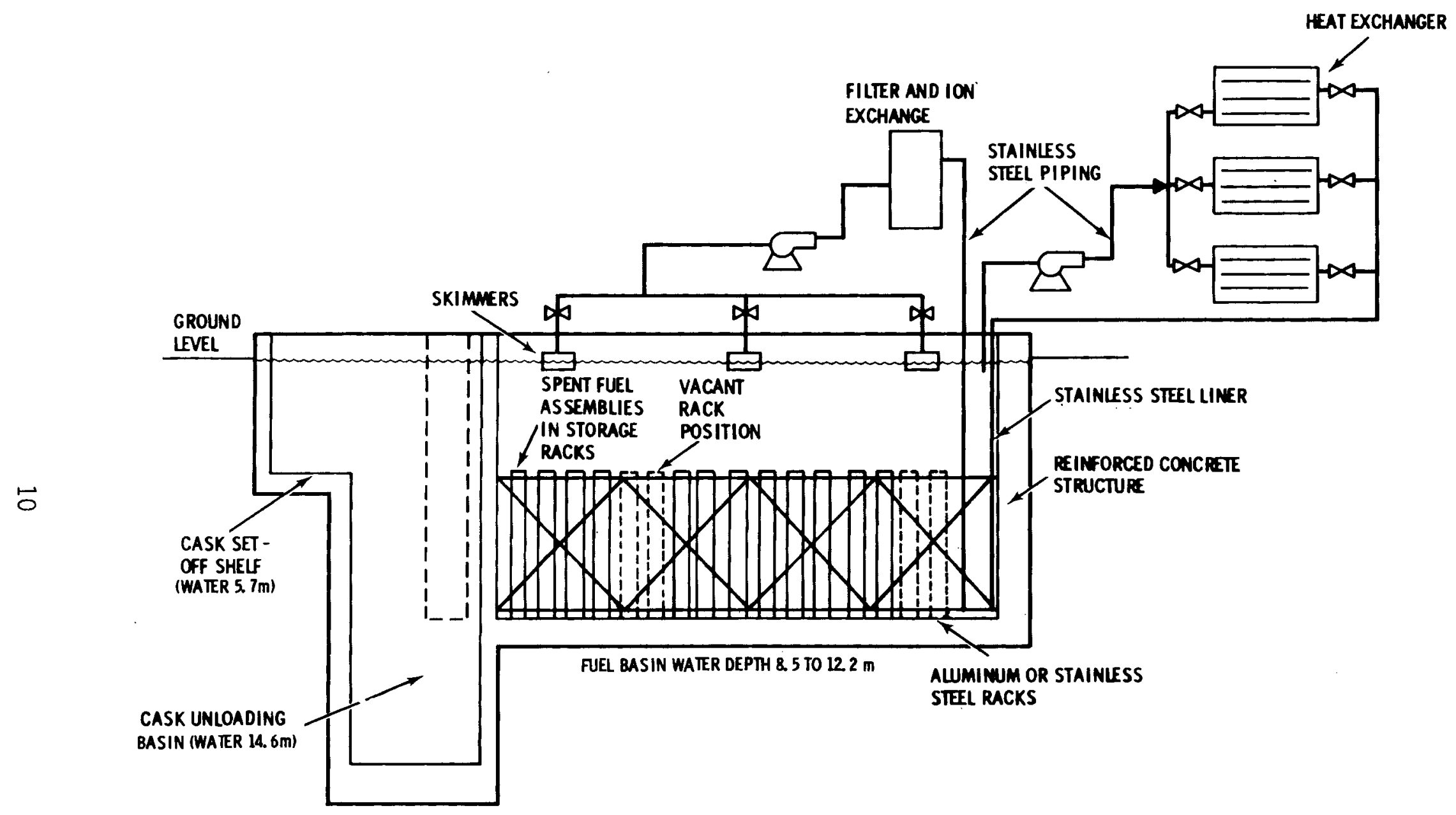

FIGURE 1. Schematic of Spent Fuel Storage Pool 


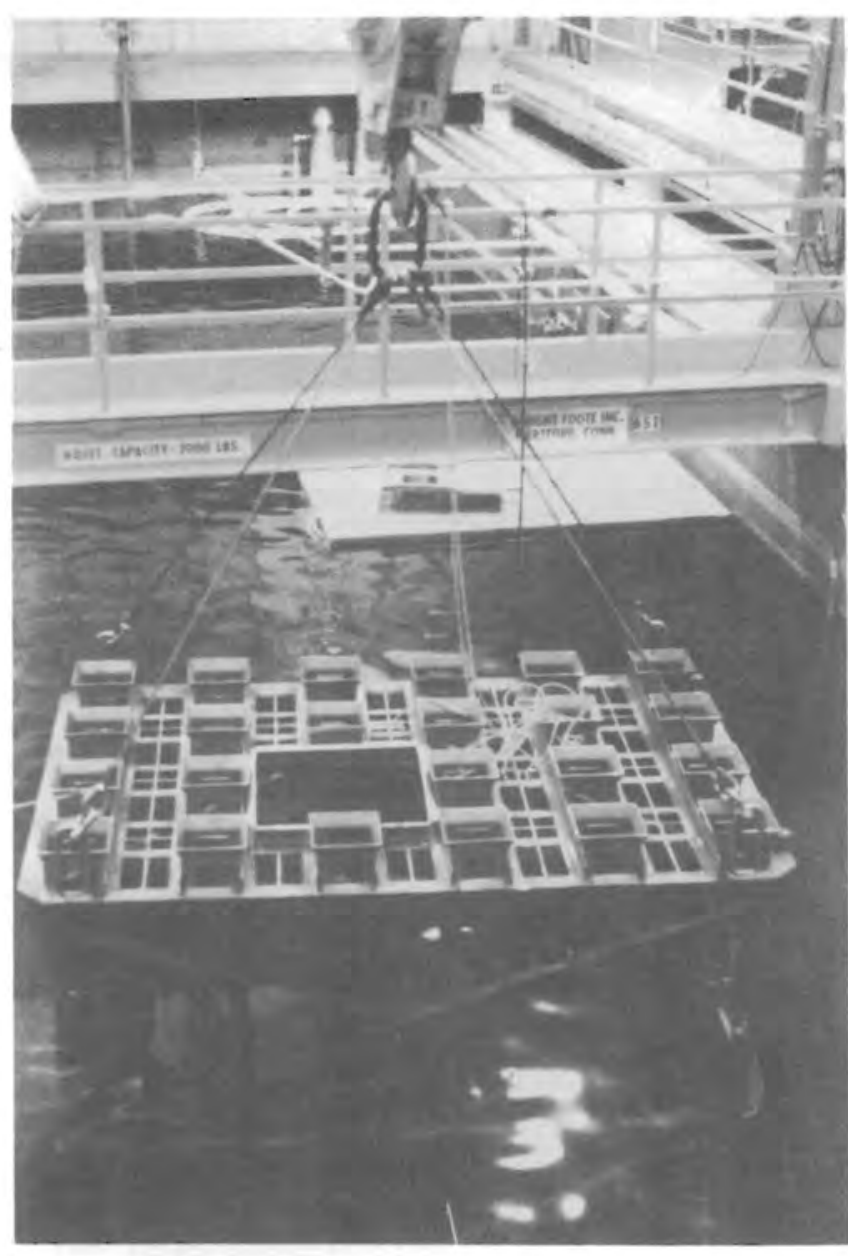

Neg. 8008771-1

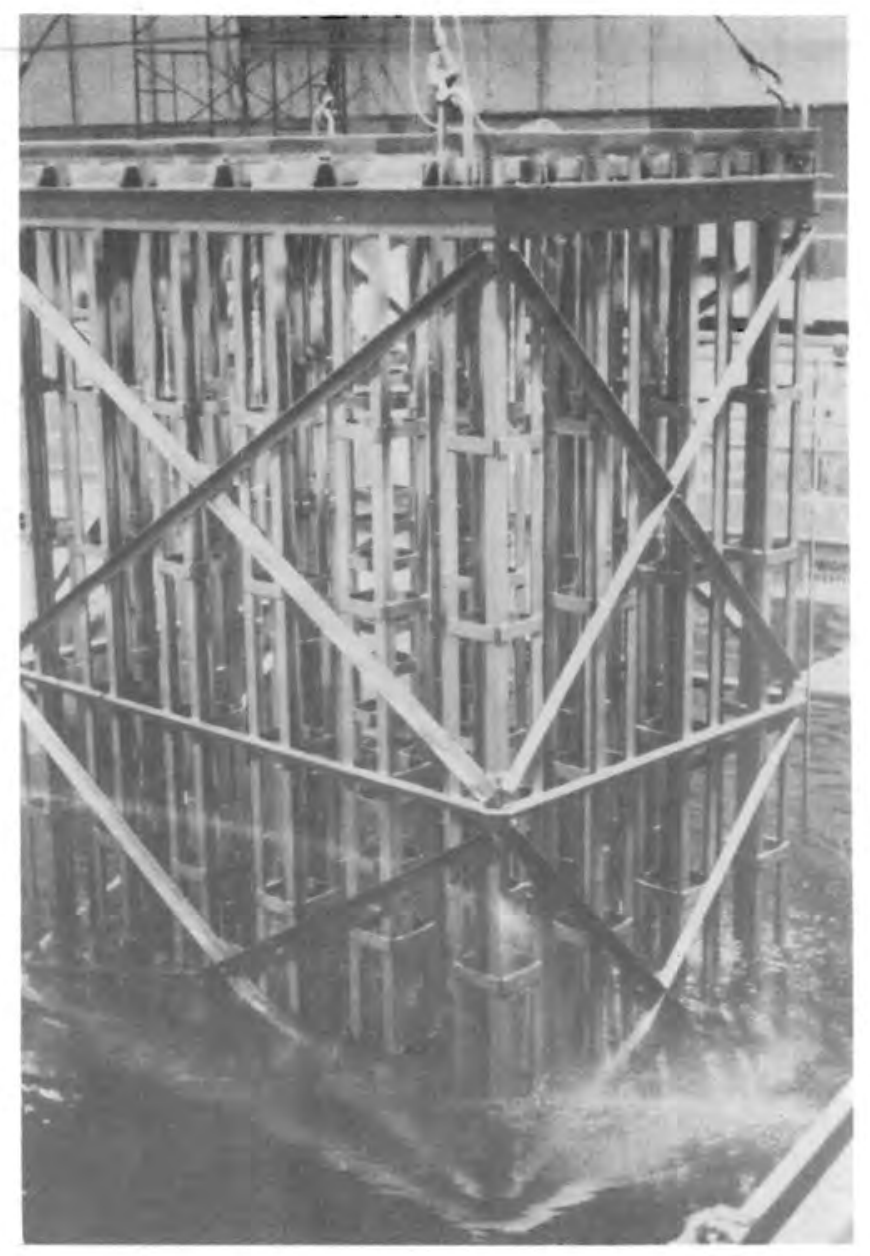

Neg. 8008771-2

FIGURE 2. Sequential Views of First-Generation Point Beach (PWR) Spent Fuel Storage Rack Being Removed from the Borated Water Pool 


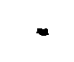

. 


\section{SPENT FUEL POOL COMPONENT EXPERIENCE}

There have been several publications $(1-6)$ that have considered the materials behavior of SFP components. Event reports that SFP operators supply to the NRC are another source of information regarding pool materials behavior.

\section{SURVEYS OF SPENT FUEL STORAGE EXPERIENCE}

A 1977 report (1) summarized spent fuel storage experience in the United States and Canada. The report centered on spent fuel behavior but included a section on behavior of SFP equipment. A Fiscal Year 1979 Annual Report (2) also included aspects of SFP equipment behavior; most of the information from that source is included in this report.

The Nuclear Energy Agency (a component of the Organization for Economic Cooperation and Development, Paris) and the International Atomic Energy Agency (IAEA), Vienna, are cooperating in a survey of world spent fuel storage experience. The survey includes requests for indications of materials behavior in SFPs, and survey results are expected to be issued in late 1981 .

From the 1977 survey and more recent discussions with SFP operators it is evident that materials problems have had a minor impact on SFP operation. Where significant materials problems have occurred, pool operators have been able to deal with them on a timely and effective basis.

\section{INSIGHTS TO SPENT FUEL POOL COMPONENT BEHAVIOR FROM EVENT REPORTS}

Malfunctions of SFP components are reported to the NRC; 44 event reports involving SFP equipment are summarized in Appendix A to provide a cross section of the types of malfunctions that have occurred. The reports do not represent a 11 events reported but may provide fuel pool designers and operators with insights that would preclude similar events. A review of the consequences indicates that there were cases where some radioactive water leaked from damaged SFP components; however, the leakage had minimal impacts because of relatively low concentrations of radioactive species (generally $10^{-2}$ to $\left.10^{-5} \mu \mathrm{C} i / \mathrm{ml}\right)$. None of the event reports indicated that the component failures resulted in human injury. 
BEHAVIOR OF ALUMINUM SPENT FUEL POOL COMPONENTS

Aluminum alloys are used for construction of spent fuel storage racks and canisters; Table 3 summarized some of the more significant uses of aluminum alloys in SFPS. Aluminum components have been used in deionized water for up to $25 \mathrm{yr}$ at the NRX reactor pool at Chalk River, Ontario, Canada (not shown in Table 3). Although aluminum racks are seldom used in boric acid (PWR) pools, they have been used in the boric acid pools at Maine Yankee (Wiscasset, Maine) and Three Mile Island-Unit 1 (Goldsboro, Pennsylvania). An aluminum rack also resided in the Yankee Rowe pool for up to $17 \mathrm{yr}$ at boric acid concentrations up to 800-ppm B as boric acid.

Due to the need for an increased storage capacity in most power reactor SFPs, neutron-absorbing material such as boral is being extensively used to fabricate high-density storage racks. Boral consists of an aluminum/boron carbide cermet encased in aluminum; this material has been used in the Brookhaven Medical Research Reactor fuel storage area since January 1959 (3) as well as in Yankee Rowe, Maine Yankee, La Crosse, and other nuclear power plants. Water leakage into boral that is sealed in stainless steel has led to swelling due to hydrogen production of the incasement. Radiolytic decomposition of organic binder compounds in $B_{4} C$ compacts appears to have been another source of gaseous hydrogen in spent fuel storage racks. Currently, racks are designed with vent holes at the tops of the rack panels to keep hydrogen pressures from developing. 
EXAMINATION OF A YANKEE ROWE (PWR) STAINLESS STEEL SPENT FUEL POOL

RACK SUPPORT SECTION

A section of a SFP rack support from Yankee Rowe was received at PNL for metallurgical examination on February 22, 1979. It had a total surface activity of $3.74-\mu \mathrm{Ci}{ }^{60} \mathrm{Co}$ (January 4 , 1979) with smearable contamination of $500 \mathrm{dpm} / \mathrm{cm}^{2}$. Figure 3 shows the layout of the SFP area and indicates where the rack section was removed. Table 7 indicates the chemical analysis performed on samples from vertical and horizontal plates of the rack support and the nominal conditions for the pool water. The rack section was exposed in the pool for $\sim 17$ months (from December 1975 to May 1977).

The overall size and geometry of the rack support section is shown in Figure 4. It consisted of a piece of 6.35-mm (1/4-in.) 304 SS angle with 7.6-cm (3-in.) flanges attached by threaded rods and weldments to a solid $9.5-\mathrm{cm}$ (3-3/4-in.) square 76.12-cm (28-in.) long billet. The billet was nonmagnetic and had a crusty brown surface scale, which suggested that it was a low-grade, low-chromium austenitic stainless steel (e.g., alloy 501). The SS angle was slightly discolored in spots but generally had a bright finish. It was characterized by a flame-cut edge (from removal operations) and an abbreviated double-T welded joint (approximately $1 / 2$ of a box end joint).

From Figure 4, it appears that a manual-shielded metal arc welding technique was used with a coated electrode as filler material (commonly 308 SS). The middle macrograph shows slag entrapment at the weld-base metal fusion line and local grinding marks. The weld spatter observed in the right macrograph is caused by excessive welding current or a variation in the metal transfer from nonhorizontal welding positions. (7) A heat-tinting effect is also seen in the photographs, indicating areas of the plates that were exposed to high temperatures during the joining process. The weld beads and fusion line areas appear structurally sound with no visual pits or surface cracks.

YANKEE ROWE MICROSTRUCTURAL ANALYSIS

A section of the 304 SS angle, including two weldments, was prepared for optical microscopy. Microstructural examinations were performed at the points 
THIS SECTION OF FLOOR

WAS EXPOSED TO WATER $1 / 4^{\prime \prime}=1$ '

FROM 12/75 TO 5/77

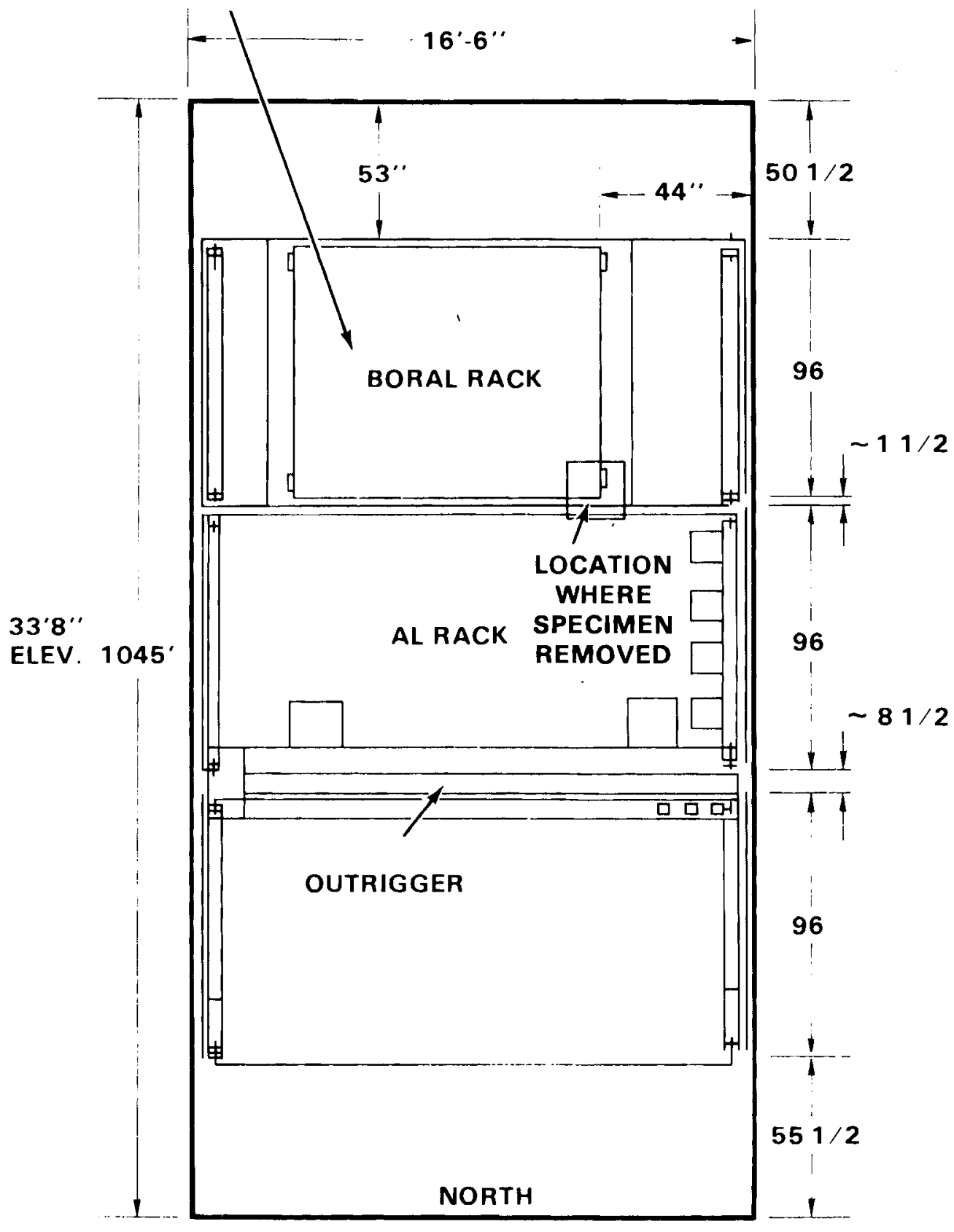

(3) PCS $13 / 4$ CYPRESS +

$1 / 16$ STAINLESS $\times 8^{\prime} \times 16^{\prime}$

FIGURE 3. Schematic of Top View of Yankee Rowe Spent Fuel Pool 
TABLE 7. Rack Support Specimen Compositions and Pool Conditions(a) for Yankee Rowe Spent Fuel 304 SS Rack Support

\begin{tabular}{|c|c|c|c|c|c|c|c|c|c|c|c|c|c|c|c|}
\hline & & & & & & & & & & osit & 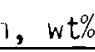 & & & & \\
\hline & terial & $c^{(c)}$ & Mn & $\mathrm{P}$ & 3 & $\mathrm{Si}$ & $\mathrm{Ni}$ & $\mathrm{Cr}$ & Mo & V & $\mathrm{Cu}$ & $S n$ & $\mathrm{Ti}$ & Al & $\mathrm{Co}$ \\
\hline & 304 SS & 0.07 & 1.6 & 8 & & 0.48 & 9.69 & & 0.41 & 0.033 & 0.28 & 0.14 & 0.008 & 07 & 30 \\
\hline rtical Plate & 304 SS & 0.07 & 1.63 & 0.027 & 0.016 & 0.47 & 9.26 & 18.17 & 0.41 & 0.032 & 0.27 & 0.015 & 0.008 & 0.008 & 0.118 \\
\hline
\end{tabular}

(a) Pool Conditions

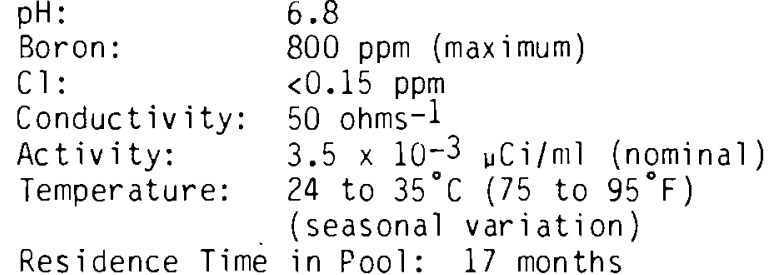

(b) Analys is performed by Jorgensen Steel Co., Seattle, Washington.

(c) Performed by LECO method. 


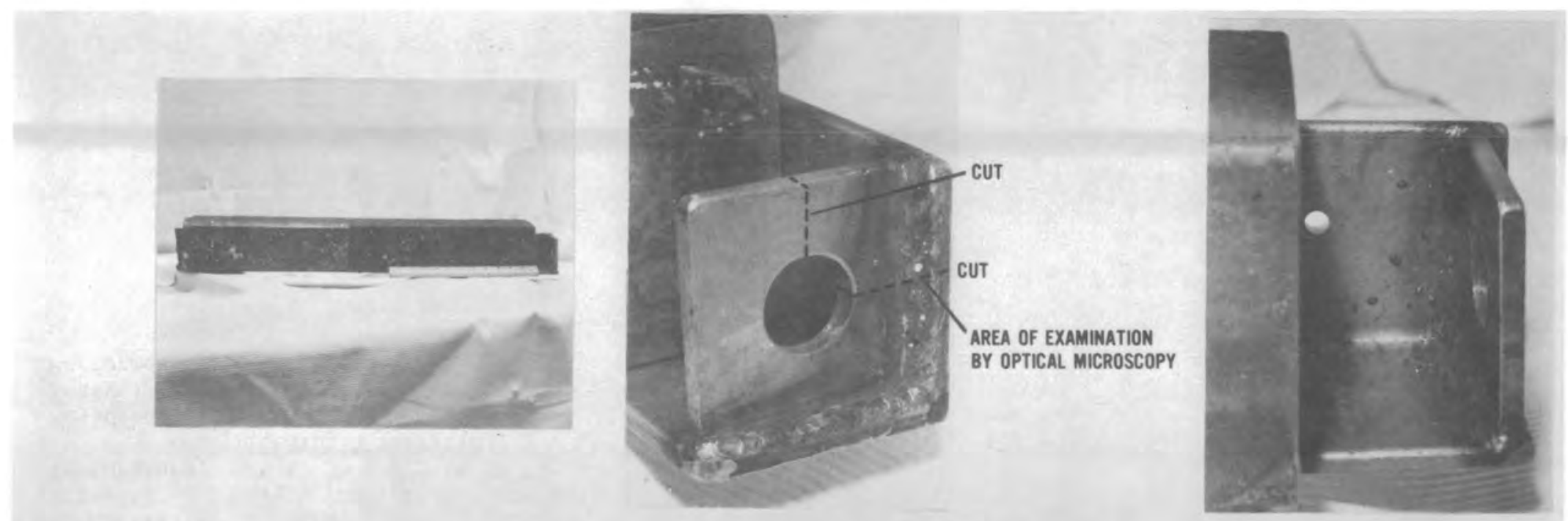

MACROGRAPHS OF SECTION FROM SPENT FUEL POOL. RACK SUPPORT

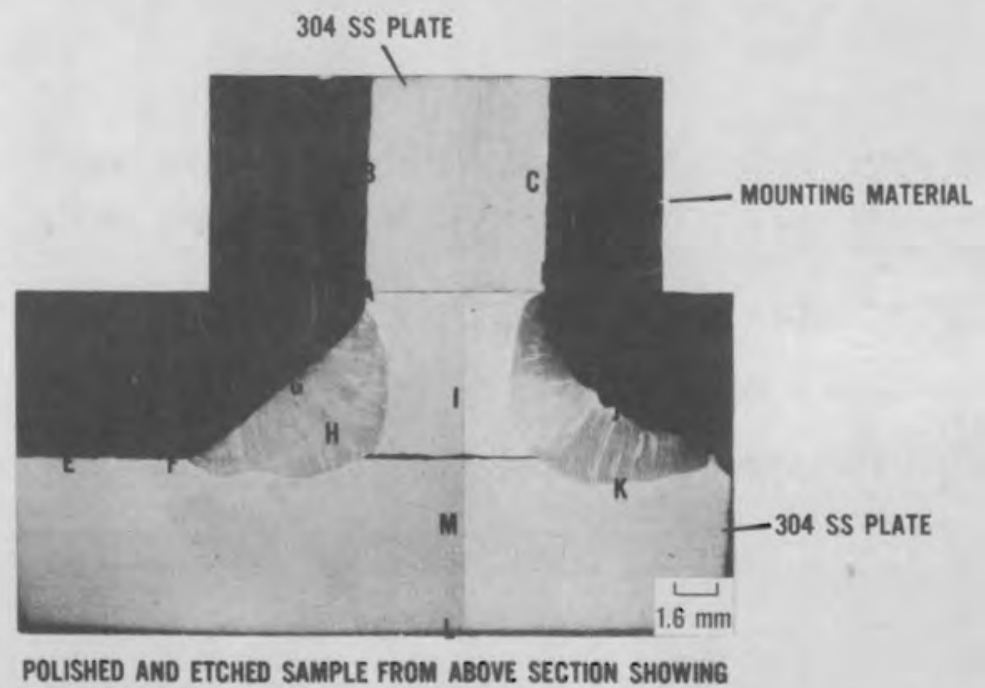

Neg. No. $7906172-2$

POLISHED AND ETCHED SAMPLE FROM ABOVE SECTION SHOWING AREAS EXAMINED WITH OPTICAL MICROSCOPY

FIGURE 4. Metallographic Examination of a Yankee Rowe (PWR) Spent Fuel Pool Rack Support Section (304 SS). Exposed to 800-ppm B as boric acid for 17 months at 24 to $35^{\circ} \mathrm{C}$ 
shown on the lower micrograph in Figure 4 and are shown in Figures 5, 6, and 7 . The major points of interest are:

- a grain boundary penetration zone at points $A$ and $D$ on the vertical plate; other surface locations (points B, E, F, L) lacked this zone

- a plate microstructure characterized by equiaxed grains ( 0.033-mm diameter ASTM \#7) with elongated inclusion stringers depicting rolling direction and by transgranular twins

- a nonuniform distribution of grain boundary precipitates as shown in Figure 8

- a dendritically solidified weld metal (austenite with delta ferrite constituents) free of visual defects with a small precipitate-free zone extending inward from the fusion line

- an entrapment of slag within the joint space separating the vertical and horizontal plates

- evidence of local deformation of surface grains in the form of slip bands running transgranularly through the matrix. Detailed examination of the localized grain boundary penetrated zones at points $A$ and $D$ in Figure 5 reveals the following:

- a zone of shallow intergranular attack $\sim 1 \mathrm{~mm}$ in length that initiates at the fusion 1 ine and extends $\sim 25$ to $80 \mu \mathrm{m}$ into the base metal

- a decreasing depth of grain boundary penetration and surface grain size with increasing distance away from the fusion line

- an increasing density of grain boundary precipitates in surface regions with increasing distance from the fusion line

- removal of surface grains in areas adjacent to the fusion line

- grain boundary widening, with grain boundary precipitates residing along the affected boundaries. 


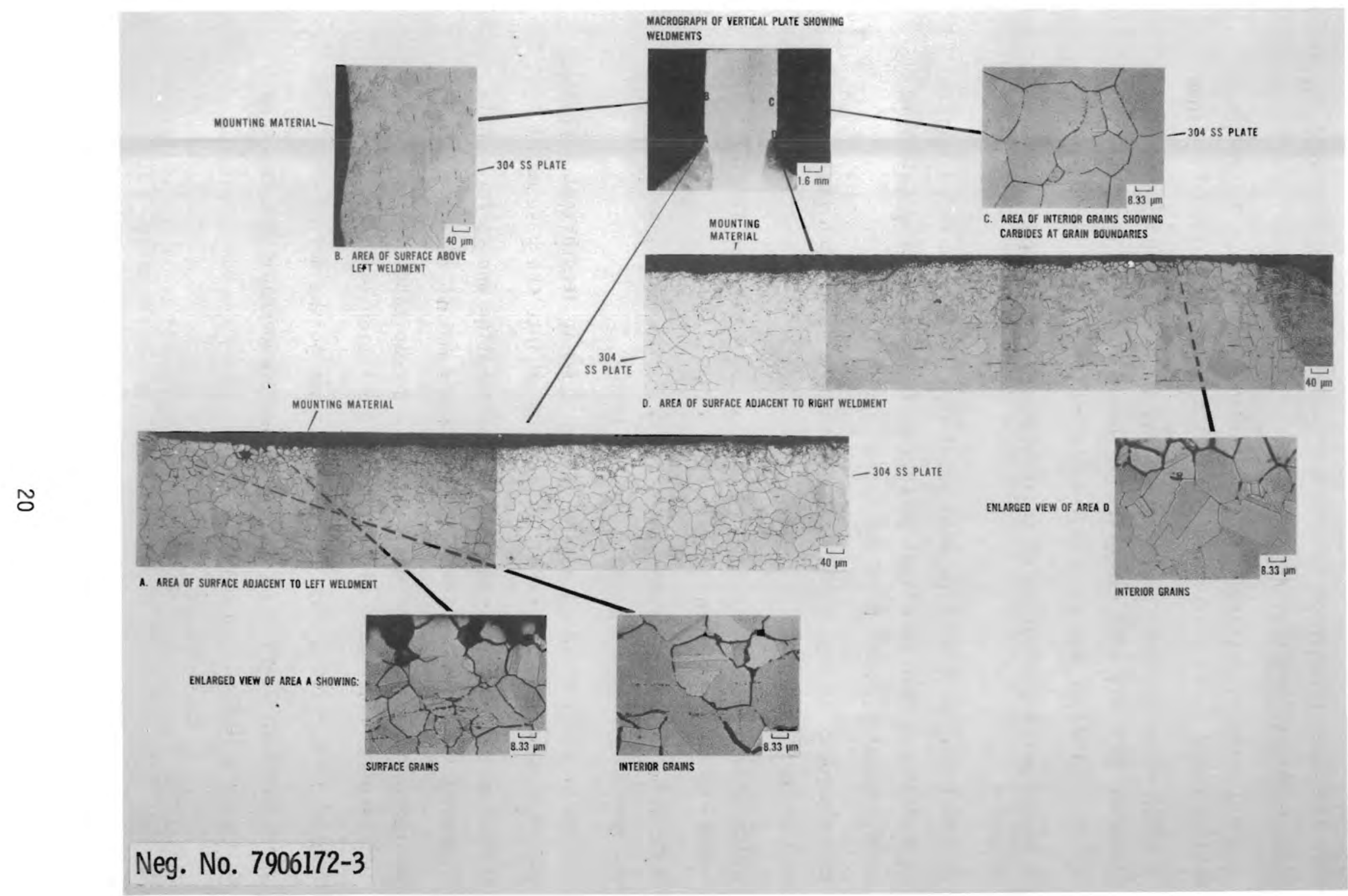

FIGURE 5. Metallographic Examination of Yankee Rowe Vertical Plate and Weldments (304 SS). Exposed to 800-ppm B as boric acid for 17 months at 24 to $35^{\circ} \mathrm{C}$ (see Figure 4 ). 


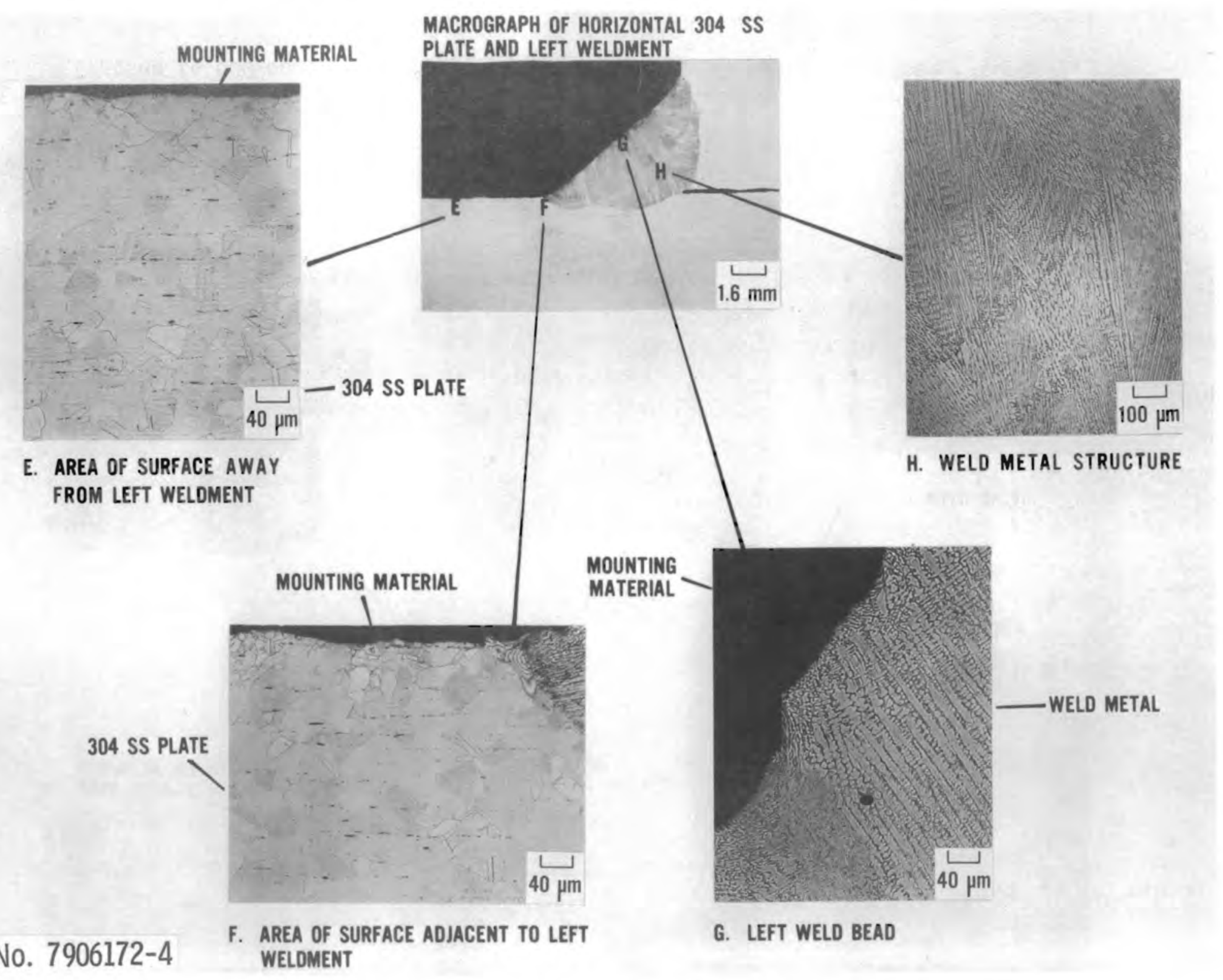

Neg. No. 7906172-4

$$
\text { AREA OF SURFACE ADJACENT TO LEFT }
$$

FIGURE 6. Metallographic Examination of Yankee Rowe Left Weldment (304 SS). Exposed to $800-$ ppm B as boric acid for 17 months at 24 to $35^{\circ} \mathrm{C}$ (see Figure 4 ). 


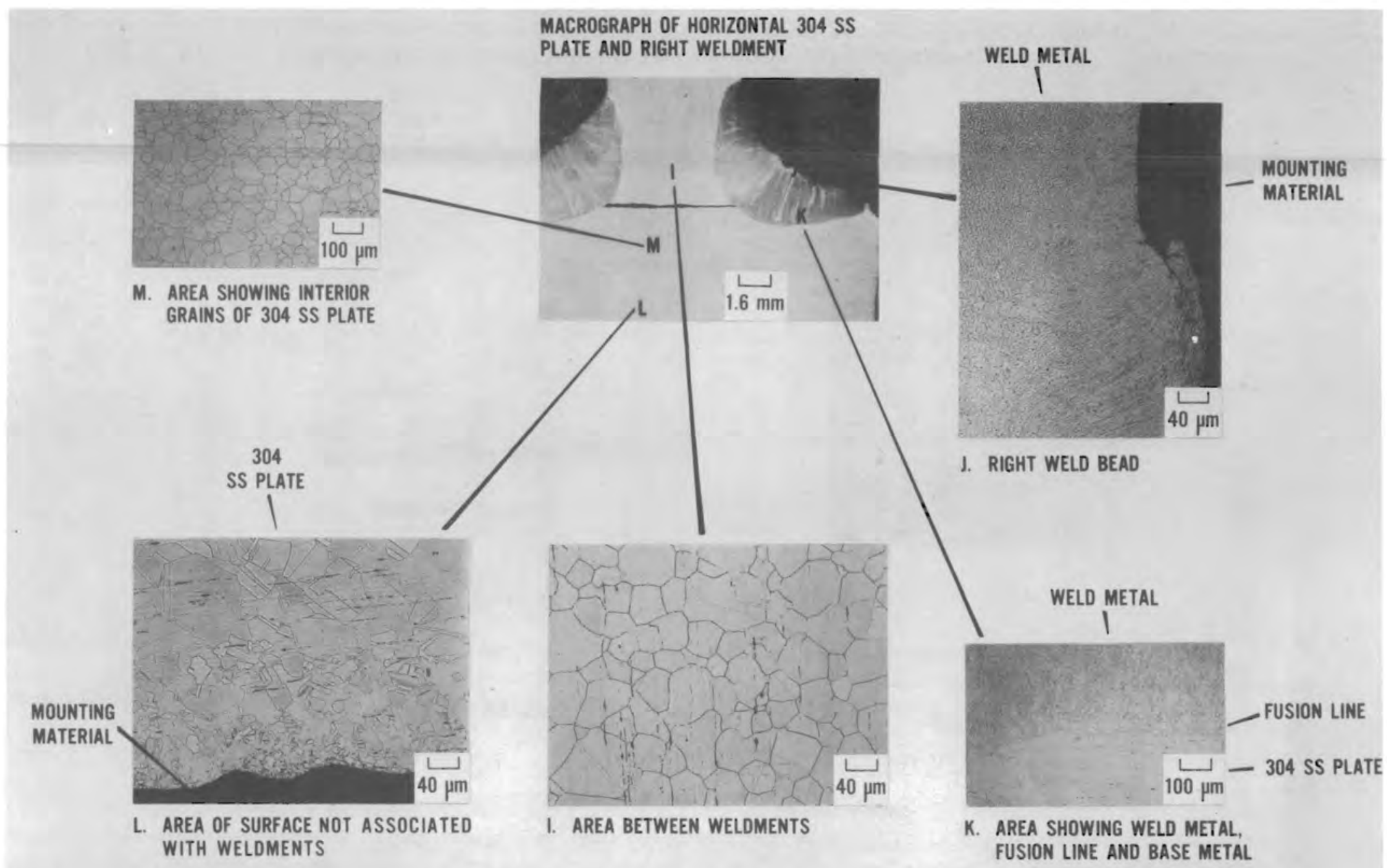

Neg. No. $7906172-1$

FIGURE 7. Metallographic Examination of Yankee Rowe Right Weldment and Horizontal Plate (304 SS). Exposed to 800-ppm B as boric acid for 17 months at 24 to $35^{\circ} \mathrm{C}$ (see Figure 4 ). 


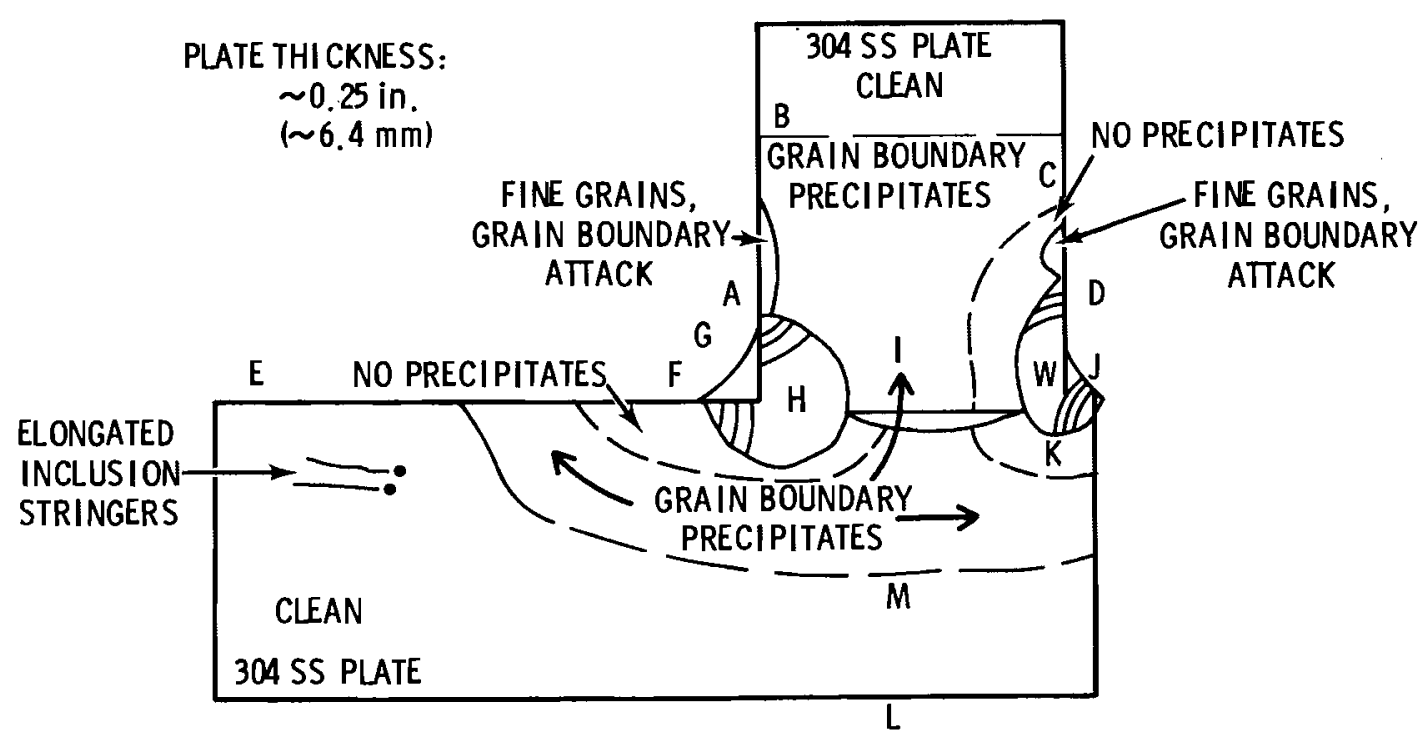

FIGURE 8. Schematic of Yankee Rowe Weldments Showing Microstructural Zones (see Figure 4)

YANKEE ROWE WELDING THERMAL HISTORY

A numerical analysis was performed to characterize the thermal history of the plates with respect to welding parameters and design considerations. Table 8 and Figures 9 and 10 show peak temperatures, cooling rates, and heataffected zone resuits. It is important to note that these values represent calculations for an initial weld pass on one side of the plate only. A second pass on the opposite side of the first weld bead could lower the cooling rates and peak temperatures significantly, depending on the interpass temperature between welding operations. Values of the above variables for three-leg heat transfer are shown, assuming that the opposite flange of the SS angle contributes to the heat removal process. These values would apply for a single pass near the $90^{\circ}$ bend area of the SS angle.

A summary of heat transfer equations, thermal properties, design considerations, and assumptions for the thermal analys is is included in Appendix $C$.

\section{DISCUSSION OF YANKEE ROWE SPENT FUEL POOL RACK SUPPORT SECTION}

The welding of austenitic stainless steels with relatively low thermal conductivity can introduce localized areas of high heat input to the base 
TABLE 8. Temperature History Analysis(a)

\begin{tabular}{|c|c|c|}
\hline \multirow{2}{*}{$\begin{array}{c}\text { Distance from } \\
\text { Weld Fusion Line, } \\
\text { mm (in.) } \\
\end{array}$} & \multicolumn{2}{|c|}{ Three-Leg Heat Transfer } \\
\hline & $\begin{array}{c}\text { Peak } \\
\text { Temperature, }{ }^{\circ} \mathrm{C} \\
\end{array}$ & $\begin{array}{c}\text { Cooling Rate, } \\
\quad \mathrm{C} / \mathrm{s} \\
\end{array}$ \\
\hline 0 & Melting Point & \\
\hline $0.5(0.002)$ & 1323 & 94.1 \\
\hline $1.0(0.04)$ & 1247 & 83.3 \\
\hline $1.5(0.06)$ & 1179 & 73.9 \\
\hline $3.0(0.12)$ & 1015 & 53.1 \\
\hline $6.4(0.25)^{(b)}$ & 773 & 26.2 \\
\hline $8.9(0.35)$ & 659 & 19.0 \\
\hline $11.9(0.47)$ & 560 & 10.3 \\
\hline $15.9(0.63)$ & 468 & 5.5 \\
\hline $20.0(0.79)$ & 402 & 3.5 \\
\hline $\begin{array}{l}\text { Sequence: Selec } \\
\text { line, calculate } \\
\text { calculate cool in } \\
\text { Appendix } c \text {. }\end{array}$ & $\begin{array}{l}\text { tance from we } \\
\text { temper ature, }\end{array}$ & jion \\
\hline
\end{tabular}

(a) References 8, 9, and 10.

(b) Thickness of plate.

metal. (8) The 304 SS is microstructurally altered when chromium diffuses to grain boundaries and reacts with carbon to form stable chromium carbides (see Figure 11). This process is called sensitization. The susceptibility of austenitic stainless steels to sensitization at moderately high $\left(550\right.$ to $800^{\circ} \mathrm{C}$ ) and relatively low $\left(\sim 300^{\circ} \mathrm{C}\right)$ temperatures is well known. (11) Sensitized, and to a much lesser extent, unsensitized austenitic materials are prone to intergranular corrosion and stress corrosion cracking (SCC) under certain environmental conditions. (12-15) Several mechanisms have been proposed to account for this effect, (16) including chromium-depleted grain boundary attack, grain boundary residual strain energy, precipitate-base metal electrochemical effects, and impurity segregation theories. Of these, the first and last theories appear to have the most support. 


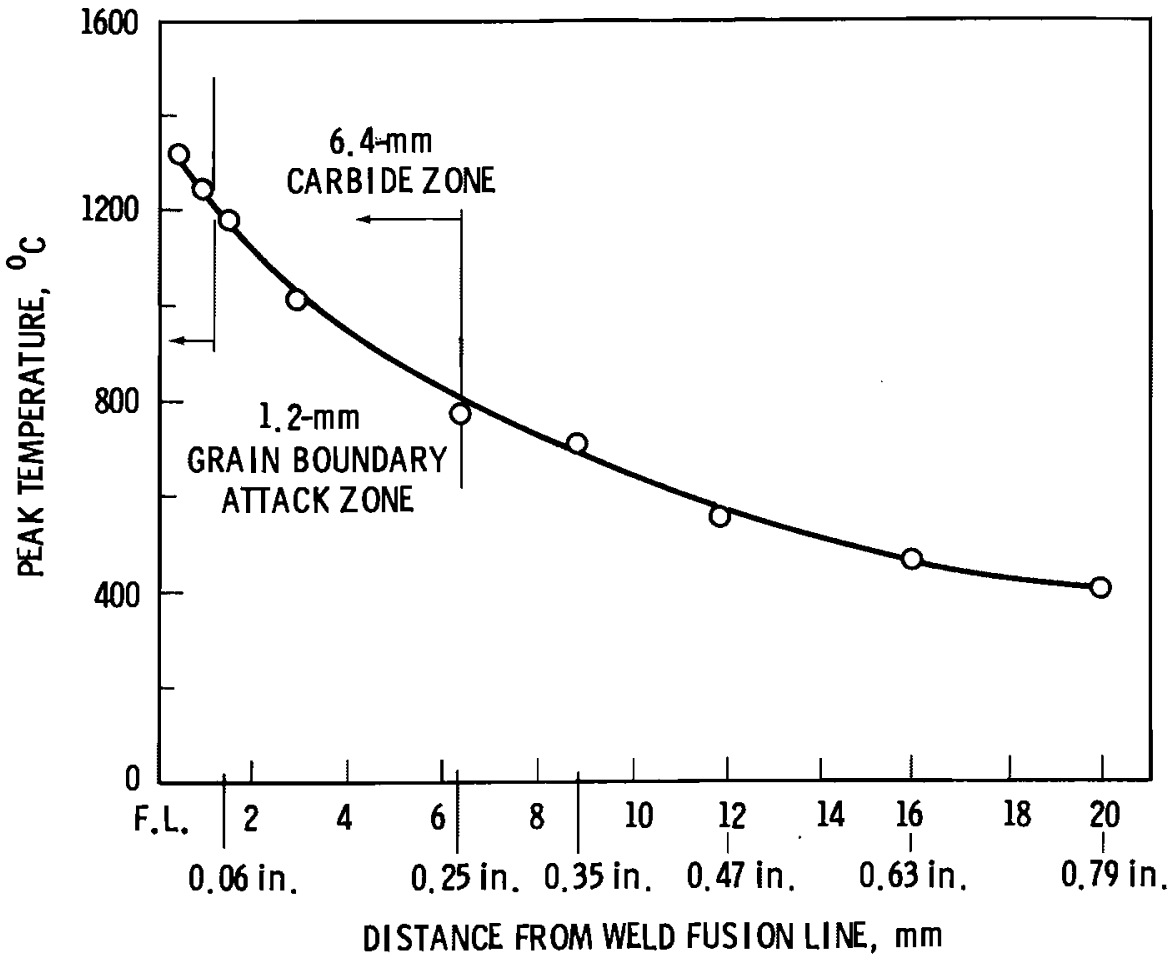

FIGURE 9. Peak Temperature Versus Distance from Weld Fusion Line

The chromium depletion theory accounts for reduced corrosion resistance if the chromium concentration falls to less than 13 weight percent (wt\%) in the vicinity of the grain boundaries. This depletion may result in intergranular attack in the chromium-depleted metal adjacent to the grain boundaries. Prolonged heating or slow cooling in the 550 to $800^{\circ} \mathrm{C}$ temperature range allows for carbide formation. Immunity of high-purity alloys to corrosion restricts the strain energy theory since all alloys contain strained grain boundaries to a certain extent.

It has been suggested that an impurity segregation model involving sulfur, phosphorus, and nitrogen deposited from nonsensitizing heat treatment $\left(1050^{\circ} \mathrm{C}\right.$ for $2 \mathrm{~h}$ ) at grain boundaries can lead to enhanced intergranular attack. (17) Sulfide inclusions in stainless steels have been observed to dissolve selectively because of thermodynamic instability with in the passive potential range for stainless steels. (18) The dissolution of these Mn-Cr-Fe sulfides took place at the boundary between the sulfide and metal matrix. Sulfide 


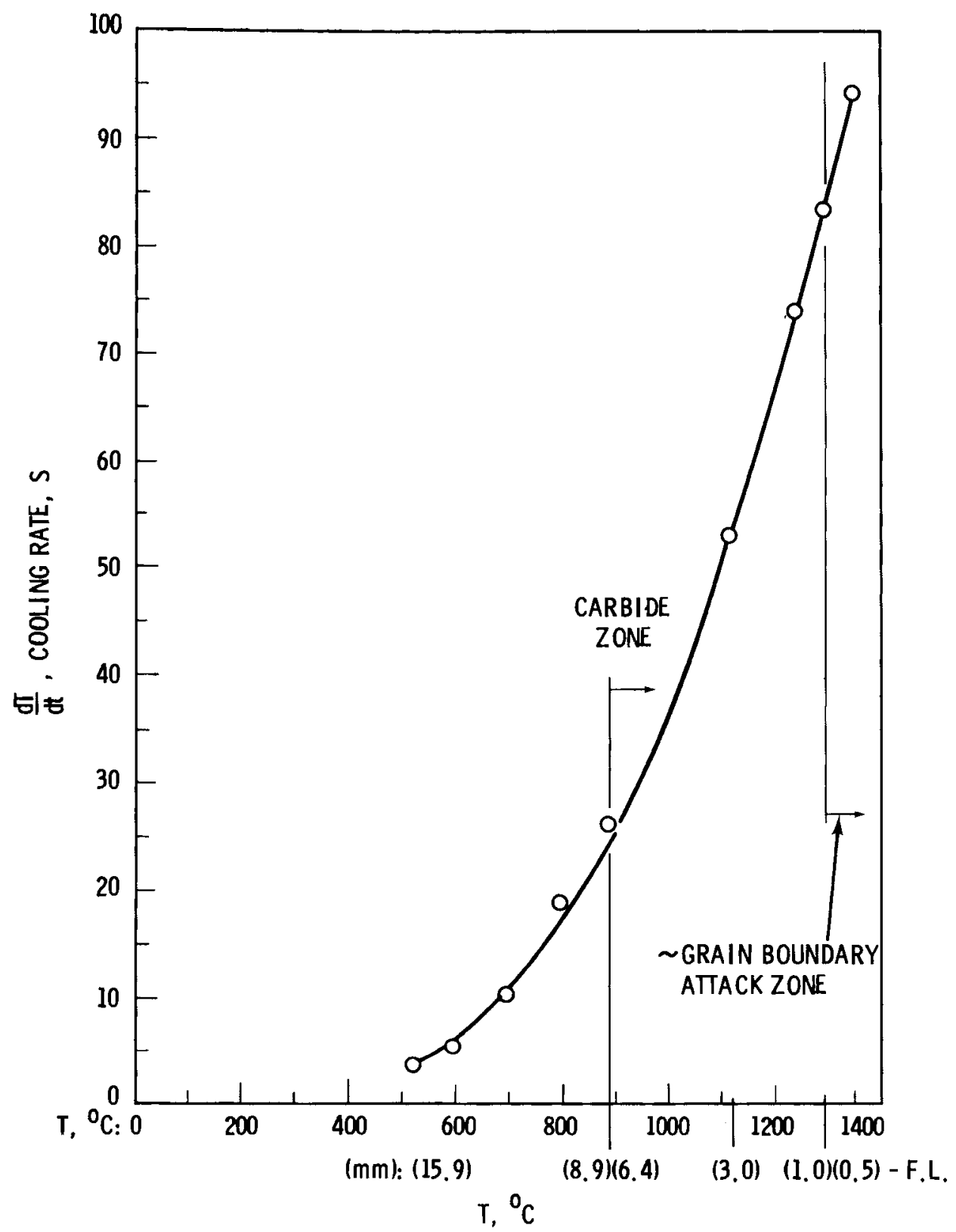

FIGURE 10. Peak Temperature Versus Distance from Fusion Line 


\begin{tabular}{|c|c|c|c|c|}
\hline HEAT-AFFECTED ZONE & SOLUTION ANNEAL ZONE & HIGH-TEMPERATURE ZONE & $\begin{array}{l}\text { WELD } \\
\text { METAL }\end{array}$ & FUSION ZONE \\
\hline STRUCTURAL CHANGES: & STRUCTURAL CHANGES: & STRUCTURAL CHANGES: & & STRUCTURAL CHANGES: \\
\hline $\begin{array}{l}\text { CHROMIUM CARBIDES } \\
\text { PRECIPITATE }\end{array}$ & $\begin{array}{l}\text { CHROMIUM CARBIDES } \\
\text { DISSOLVE }\end{array}$ & $\begin{array}{l}\text { CHROMIUM CARBIDES } \\
\text { DISSOLVE }\end{array}$ & & $\begin{array}{l}\text { GRAIN BOUNDARY } \\
\text { LIQUATION }\end{array}$ \\
\hline $\begin{array}{l}\text { CHROMIUM NITRI DES } \\
\text { PRECIPITATE }\end{array}$ & $\begin{array}{l}\text { CHROMIUM NITRIDES } \\
\text { DISSOLVE }\end{array}$ & $\begin{array}{l}\text { NIOBIUM CARBIDES } \\
\text { DISSOLVE }\end{array}$ & & \\
\hline & $\begin{array}{l}\text { NIOBIUM CARBIDES } \\
\text { PRECIPITATE }\end{array}$ & $\begin{array}{l}\text { TITANIUM CARBIDES } \\
\text { DISSOLVE }\end{array}$ & & \\
\hline & $\begin{array}{l}\text { TITANI UM CARBI DES } \\
\text { PRECIPITATE }\end{array}$ & & & \\
\hline POSSIBLE PROBLEMS: & & POSSIBLE PROBLEMS: & & POSSIBLE PROBLEMS: \\
\hline $\begin{array}{l}\text { INTERGRANULAR } \\
\text { CORROSION }\end{array}$ & & KNIFE LINE ATTACK & & HOT CRACKING \\
\hline IGSCC & & & & \\
\hline $\begin{array}{l}550 \mathrm{TO} 800^{\circ} \mathrm{C} \\
1000 \text { TO } 1450^{\circ} \mathrm{F}\end{array}$ & $\begin{array}{l}800 \text { TO } 1250^{\circ} \mathrm{C} \\
1450 \text { TO } 2250^{\circ} \mathrm{F}\end{array}$ & $\begin{array}{l}1250 \text { T0 } 1350^{\circ} \mathrm{C} \\
2250 \text { T0 } 2450^{\circ} \mathrm{F}\end{array}$ & & \\
\hline
\end{tabular}

FIGURE 11. Possible Mechanisms for Intergranular Attack on Welded Austenitic Stainless Steels

dissolution freed $\mathrm{Fe}$ and $\mathrm{Cr}$ ions that can undergo hydrolysis, contributing to a higher concentration of hydrogen ions or a lower pH. This higher acidity can restrict the repassivation of the matrix and allow for selective base metal dissolution.

In certain environments, small concentrations of chloride and fluoride ions are known to affect sensitized austenitic stainless steels adversely under stressed and unstressed conditions. (14-20) Fluoride ion attack tends to be intergranular, and decreased susceptibility has been observed for fine-grained and low-carbon content materials. (19) A potential source of fluoride contamination is the slag residue from compounds considered necessary for weld metal atmospheric protection. However, stress corrosion of welded austenitic stainless steels in SFP environments is a rare phenomenon.

The welded joint from the Yankee Rowe SFP support rack shows an unexpected selectivity for areas of intergranular attack--namely, on only two of the four heat-affected weld zones. This observation suggests either a slightly different chemical composition (e.g., carbon, sulfur, phosphorous, or nitrogen) 
or a welding procedure that could adversely affect one plate. A chemical analysis was performed on samples from the vertical and horizontal plates of the pool racks; the compositions were almost identical with only a minor variation in nickel, which would not account for impurity variations. Therefore, it appears that the thermal history from the welding operation adversely affected one plate, allowing for preferential impurity and/or carbide segregation to the attacked grain boundaries of the attacked regions (see Figure 5).

The thermal analysis described previously has shown a peak temperature of $\sim 1350^{\circ} \mathrm{C}$ close to the weld fusion line, decreasing to $\sim 600^{\circ} \mathrm{C} \sim 15 \mathrm{~mm}(0.6 \mathrm{in}$.) from the fusion line. Figure 10 suggests that the cooling rate is initially very high for areas adjacent to the fusion line, indicating a short time at these elevated temperatures. A zone of intermediate temperatures and cooling rates occurs at a distance of $\sim 4$ to $15 \mathrm{~mm}$ from the fusion 1 ine, suggesting a cumulative time/temperature history (Figure 12) conducive to carbide precipitation.

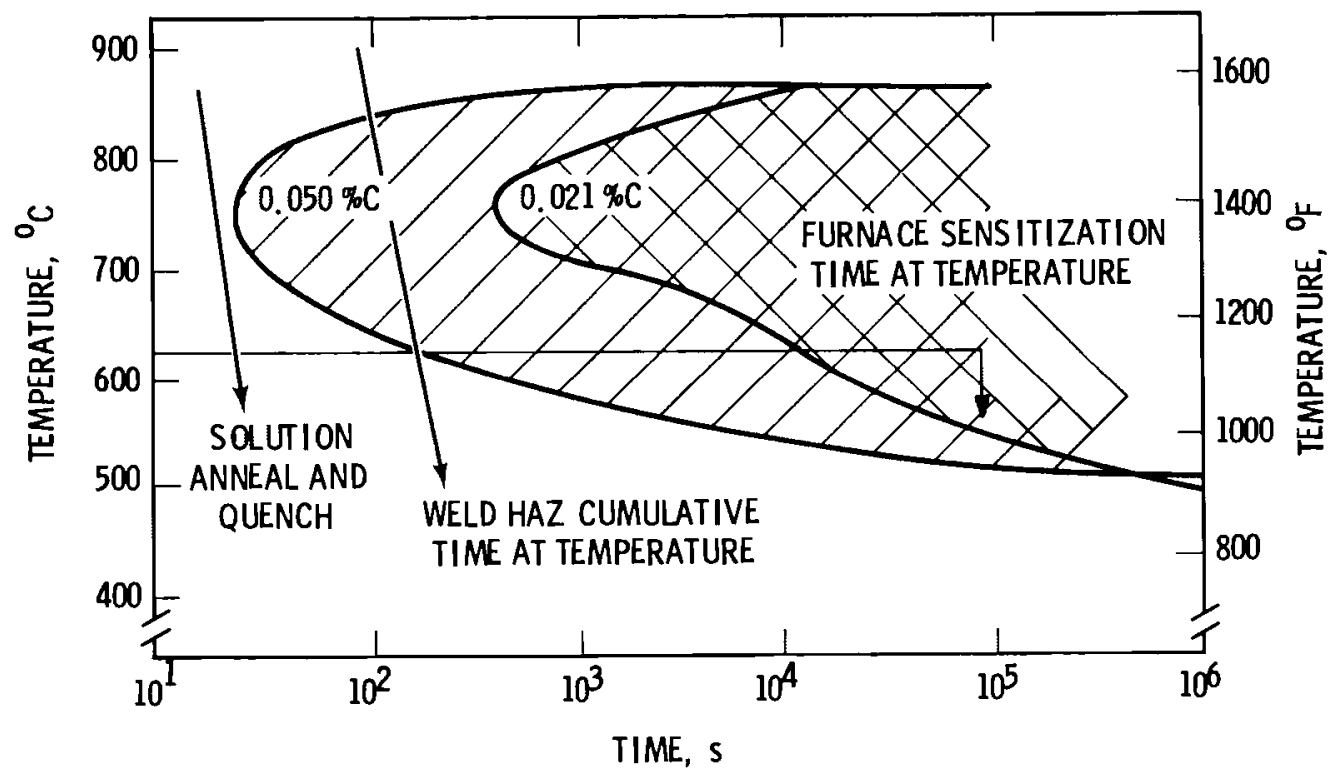

FIGURE 12. Intergranular Corrosion of 304 SS Tested in Acid Copper Sulfate Solution. Shaded areas indicate treatments resulting in intergranular corrosion. The effect of carbon content in the steels is shown as are common sensitizing and nonsensitizing thermal treatments (see Reference 21). 
A possible sequential process correlating the thermal analys is of the material with microstructural observations immediately after passage of the heat source is shown below.

1) At areas close to the fusion line, high temperatures and cooling rates dominate. The cooling from high temperatures corresponds to a progressively decreasing high-temperature anneal accompanied by carbide dissolution (see Figure 11) and impurity (e.g., sulfur) segregation to grain boundaries; this area corresponds to the larger grained material adjacent to the weld bead (areas $A$ and $D$ in Figure 5 ) and is characterized by a local intergranular attack with low density of grain boundary precipitates. This essentially carbide-free zone extends around each weldment for a finite distance from the fusion line.

2) Lower temperatures and cooling rates characterize the area adjacent to the area described above. Under these thermal conditions, certain precipitates form (depending on time-temperature history) and act as effective obstacles for grain growth. The resultant area is very fine-grained with a slight intergranular attack.

3) Far removed from the above area is a region of relatively unaffected material (area $B$ in Figure 5) with no noticeable precipitates. The grain size in this area is comparable to that of the unaffected base metal.

Since the zones of intergranular attack at points $A$ and $D$ on the vertical plate were within an area of relatively clean grain boundaries and the thermal analysis indicated very high peak temperatures and cooling rates in these regions, a nonsensitized microstructure is indicated. Recalling that fluorideinduced intergranular attack depends on a sensitized microstructure, (19) this effect does not appear to be responsible for the observed intergranular attack.

It has previously been shown that grinding operations on the inside surfaces of 304 SS pipe can introduce concentrated areas of surface cold work and a rough surface topography ${ }^{(22)}$ (similar to that observed in areas $A, B, D, E$, 
$F$, and $L$ in Figures 4 through 7 ). These effects allow for a strain-induced martensite transformation that displays poor corrosion and oxidation resistance. The combined effect of a cold-worked surface with reduced corrosion resistance and segregated impurities on grain boundaries and surface intersections could serve as potential sites for corrosion initiation.

SUMMARY AND CONCLUSIONS - YANKEE ROWE

The Yankee Rowe SFP environment consisted of a slightly acidic borated water (800-ppm B) environment at 24 to $35^{\circ} \mathrm{C}$. Areas of intergranular attack in two of four heat-affected weld zones were observed. This attack extended $\sim 1 \mathrm{~mm}$ from the fusion line and $\sim 25$ to $80 \mu \mathrm{m}$ into the base metal. No other significant attack was observed. The T-joint weldment was exposed to the above conditions for $\sim 17$ months. A corrosion data survey conducted by the National Association of Corrosion Engineers (NACE) (23) listed a corrosion rate of $<25 \mu \mathrm{m} / \mathrm{yr}$ for 304 SS in a very dilute boric acid-water environment; the maximum depth of attack observed was $\sim 75 \mu \mathrm{m}$ in a very localized area. The local intergranular attack can be attributed to a combination of high heat input welding and austenitic stainless steel with a relatively high carbon content. Of the 20 SS welds inspected by metallography (Table 1), two of the four Yankee Rowe welds were the only ones where shallow intergranular corrosion occurred. 
EXAMINATION OF A POINT BEACH (PWR) SPENT FUEL STORAGE RACK SECTION

A 304 SS section of a SFP rack from the Point Beach Nuclear Plant, Two Creeks, Wisconsin, was received at PNL for examination on May 30, 1979. The rack section and a SS nut and square washer used to anchor the racks to the floor were also supplied.

Figure 13 shows the location of the rack in the SFP; Figure 14 shows where the samples originated. Figure 15 is a view of the rack removed from the reactor pool in a reracking operation and indicates the section where the sample was removed (see arrow). Figure 16 shows the welded area from the rack section and the SS nut and square washer; four weld areas were examined metallographically.

Table 9 shows the elemental analysis of the two metal plates joined at the weld. The rack section, nut, and washer were exposed to the pool water conditions shown in Table 9 for $6.7 \mathrm{yr}$ (from September 7, 1972, to May 8, 1979). The concentration ranges for radioactive isotopes in the pool water are summarized in Table 10.

POINT BEACH RADIOACTIVITY ANALYSIS

The section of Point Beach fuel storage rack had a total $\mathrm{B} / \mathrm{\gamma}$ surface reading of $165 \mu \mathrm{Ci}$; the principal isotopes were ${ }^{58} \mathrm{Co},{ }^{60} \mathrm{Co},{ }^{106} \mathrm{Ru}$, ${ }^{134} \mathrm{Cs},{ }^{137} \mathrm{Cs}$, and ${ }^{54} \mathrm{Mn}$.

On June 1, 1978, radiation readings from a hand-held meter indicated $\sim 2.5 \mathrm{mR} / \mathrm{h}$ (shielded) on the inner plastic package and 7 to $8 \mathrm{mR} / \mathrm{h}$ on the same package with no shield for low-energy beta radiation.

Figure 17 shows the section of SFP rack with a detailed account of amounts and locations of radioactivity. Activities on the nut and washer are shown in Figure 18. 
$\stackrel{\omega}{\sim}$

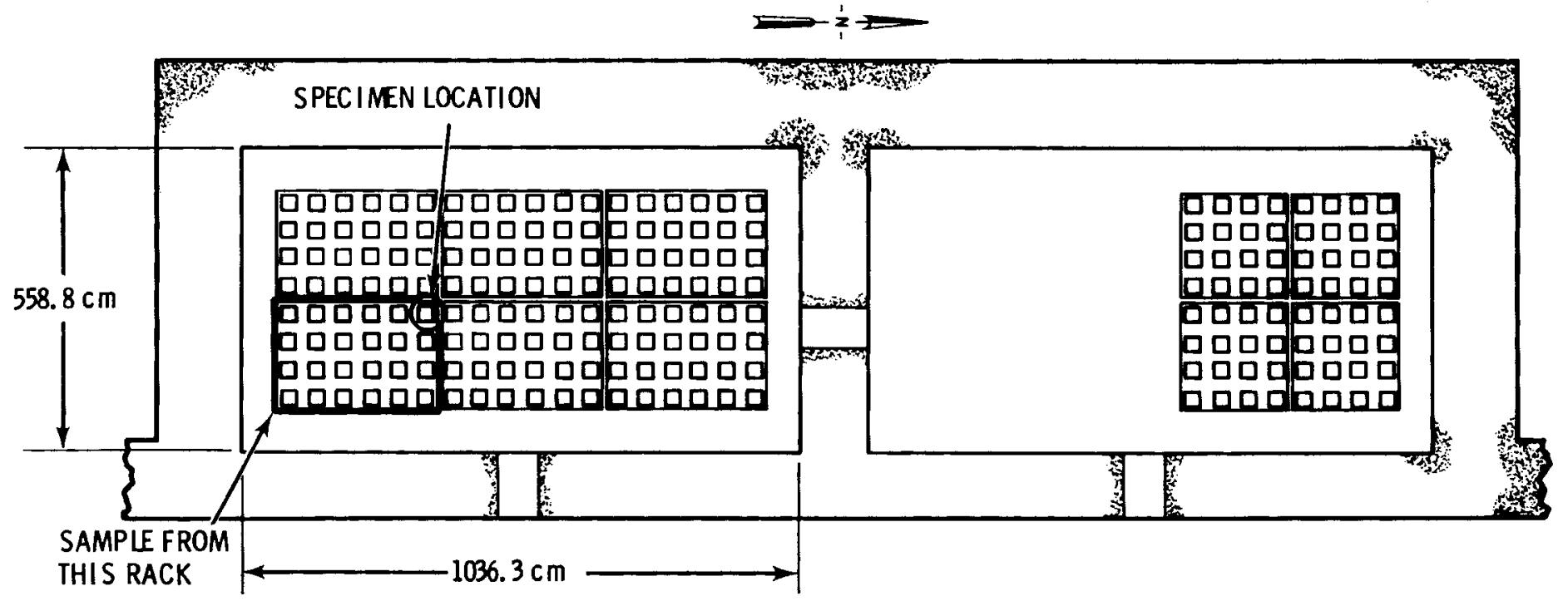

FIGURE 13. Plan View of Spent Fuel Storage Racks in Point Beach (PWR) Pool 

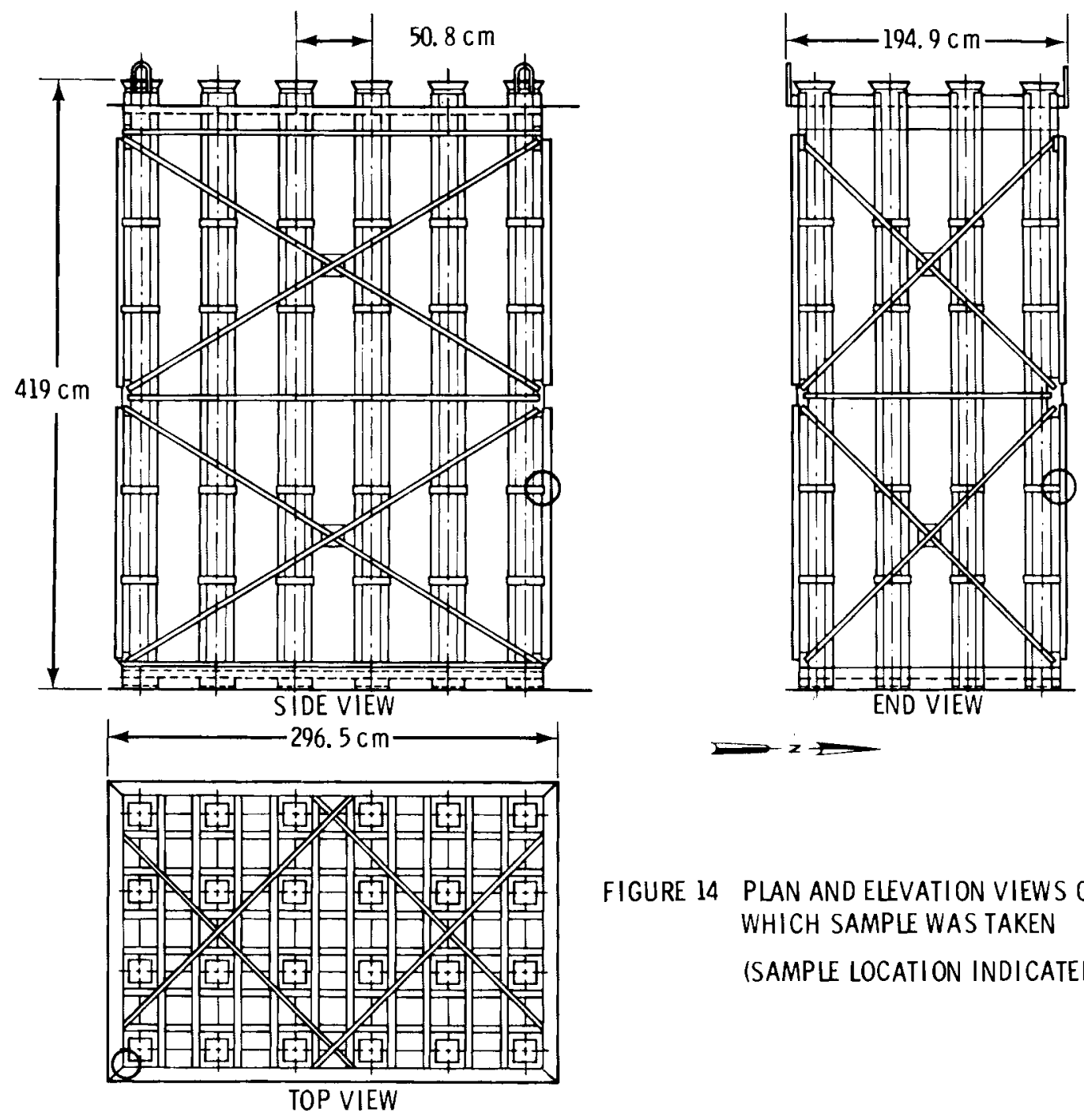

FIGURE 14 PLAN AND ELEVATION VIEWS OF RACK FROM WHICH SAMPLE WAS TAKEN

(SAMPLE LOCATION INDICATED BY CIRCLES)

FIGURE 14. Plan and Elevation Views of Point Beach Fuel Storage Rack from Which Specimen Was Taken (specimen location indicated by circles)

\section{POINT BEACH MICROSTRUCTURAL ANALYSIS}

Figure 19 shows the storage rack specimen as it was sectioneo (five locations). Pieces 1 and 3 were analyzed for radioactivity using a germanium-1 ithium detector.

The major element compositions ( $\mathrm{Ni}, \mathrm{Cr}$ ) are approximately equal on the two plates with slight variations in minor alloying elements (Mn, Si). The carbon content and impurity elements (P, S) are within ASTM specifications for 


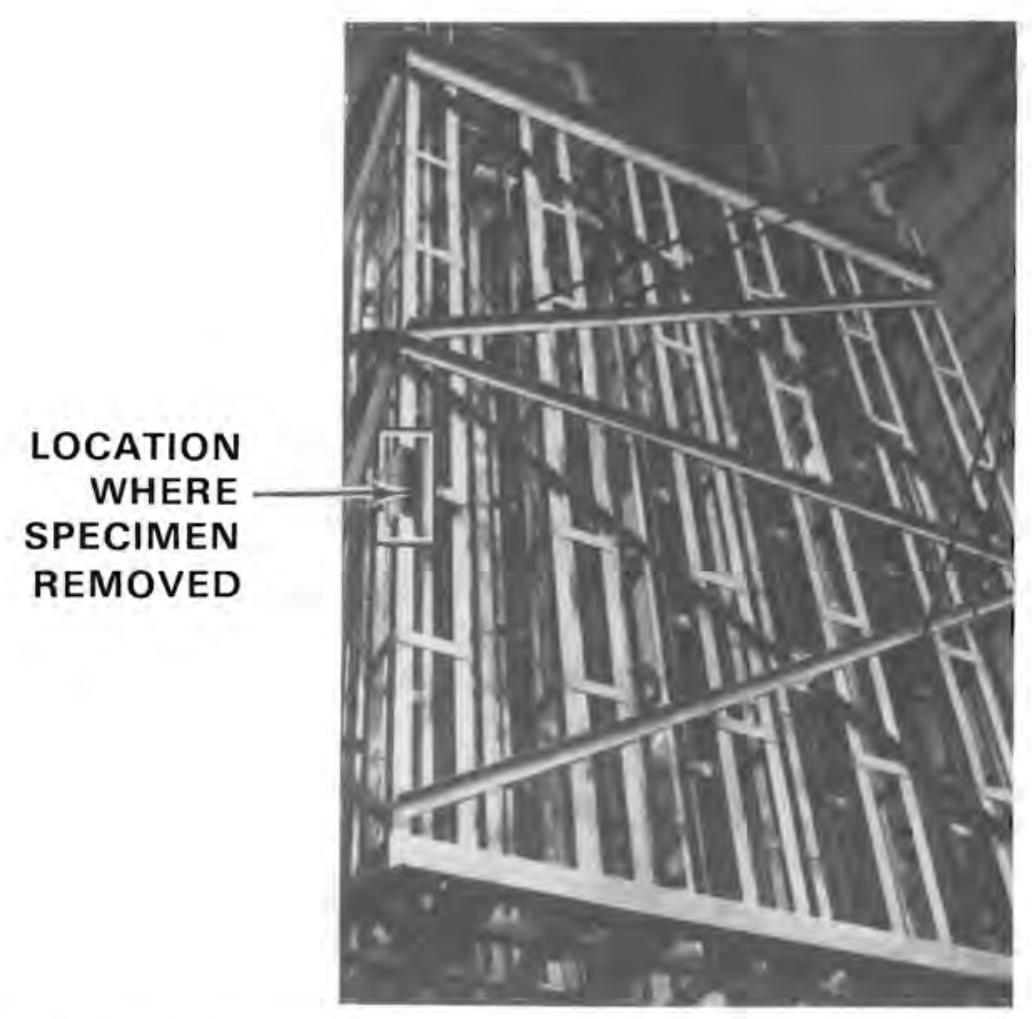

Neg. 7912715-1A

FIGURE 15. Type 304 SS Spent Fuel Pool Rack After 6.7 yr in Point Beach (PWR) Pool

nominal 304 SS (see Appendix B). Metallographic examination of two weld areas (see Figure 20) indicated no significant evidence of intergranular attack or other degradation.

The microstructural analysis suggested different processing histories for the two plates. The top plate in Figure 20 exhibited equiaxed austenitic grains indicating a mill-annealed condition. The lower angle plate had a cold-worked microstructure, characterized by inclusions and elongated austenitic grains aligned with the rolling direction.

The welds appear to be structurally sound with a dendritically solidified structure of delta ferrite islands within an austenite matrix. Areas adjacent to the fusion line show a fine-grained matrix of recrystallized grains next to the base metal; the base metal is characterized by large, carbide-free austenite grains formed by rapid cooling through the sensitization range. 


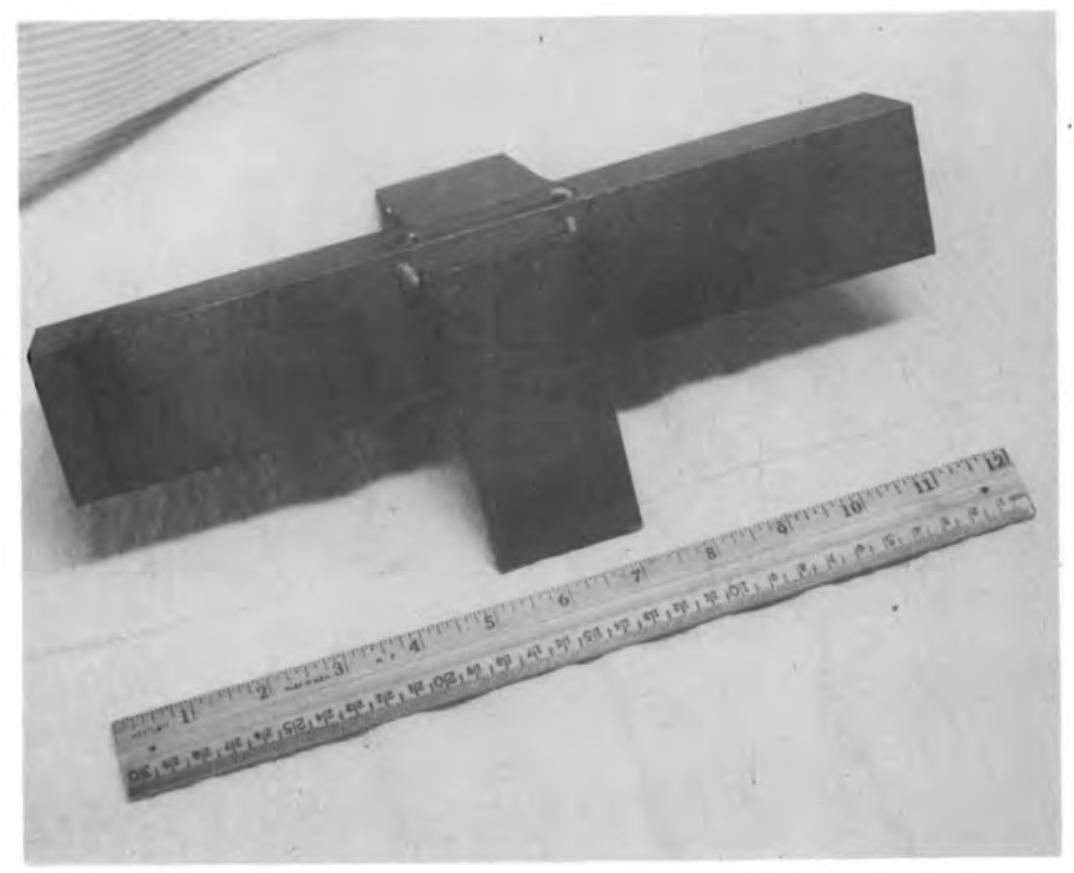

Neg. 790465-4

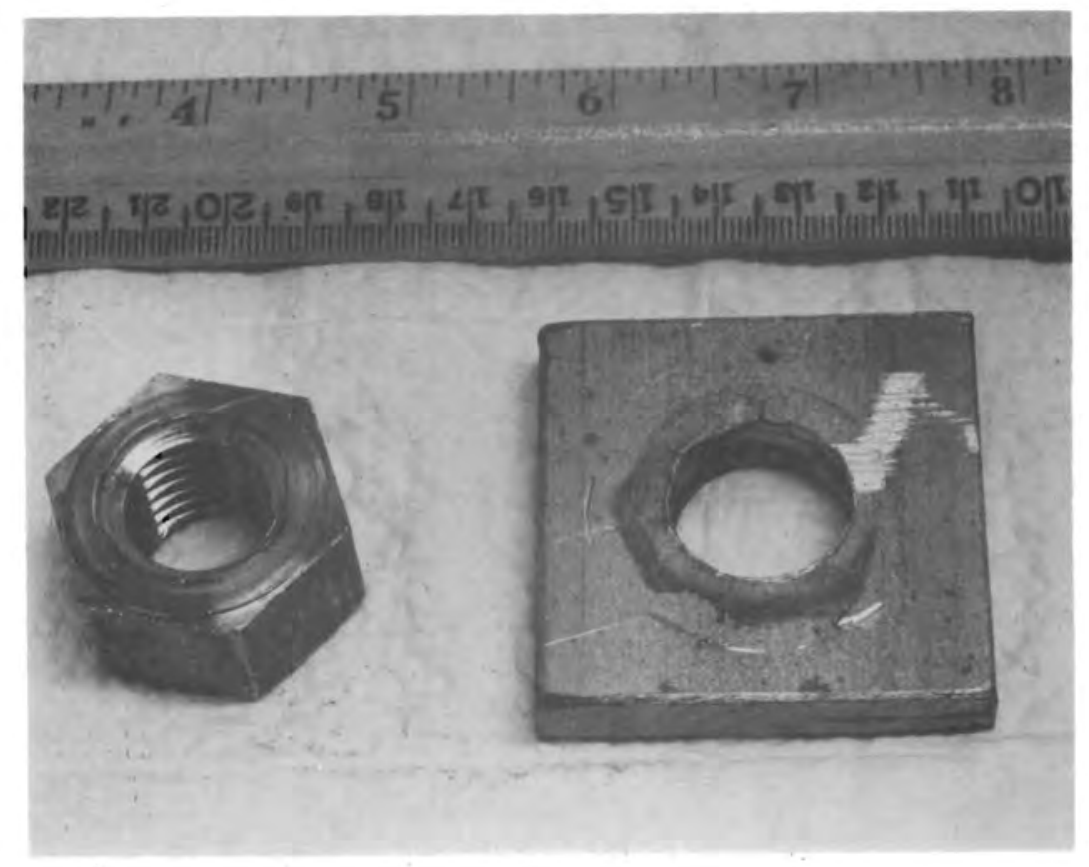

Neg. $790465-5$

FIGURE 16. Views of Rack Section, Nut, and Washer from Point Beach Rack (304 SS). Exposed to $2000-\mathrm{ppm} \mathrm{B}$ as boric acid for $6.7 \mathrm{yr}$ at 16 to $45^{\circ} \mathrm{C}$. 
TABLE 9. Rack Specimen Compositions and Pool Conditions(a) for Point Beach Spent Fuel 304 SS Rack

\begin{tabular}{|c|c|c|c|c|c|c|c|c|c|c|c|c|c|c|c|}
\hline \multirow[b]{2}{*}{ Heat } & \multirow[b]{2}{*}{ Material } & \multicolumn{14}{|c|}{ Rack Specimen Composition, (b) wt\% } \\
\hline & & $c^{(c)}$ & $\mathrm{Mn}$ & $P$ & $s^{(d)}$ & $\mathrm{Si}$ & $\mathrm{Ni}$ & $\mathrm{Cr}$ & Mo & V & $\mathrm{Cu}$ & Sn & $\mathrm{Ti}$ & $\mathrm{Al}$ & Co \\
\hline PB1 & 304 SS & 0.04 & 1.71 & 0.015 & 0.025 & 0.69 & 8.45 & 18.04 & 0.16 & 0.026 & 0.08 & 0.008 & 0.008 & 0.012 & 0.121 \\
\hline 85 & 304 SS & 0.05 & 0.48 & 0.040 & 0.021 & 0.39 & 8.17 & 18.74 & 0.36 & 0.050 & 0.22 & 0.011 & 0.008 & 0.009 & 0.165 \\
\hline
\end{tabular}

(a) Pool Conditions

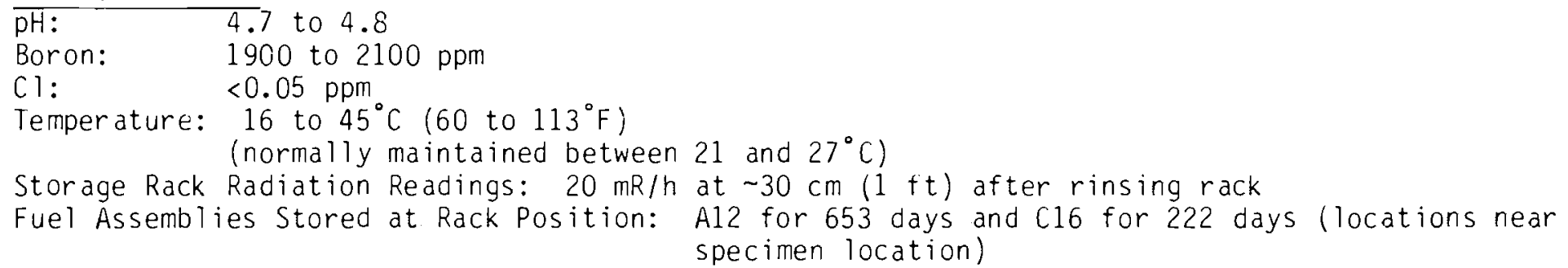

(b) Racks supplied by Bechtel to Specifications ASTM-A240 and A276. Analysis performea by Jorgensen Steel Co., Seattle, Washington.

(c) 0.045 and 0.065 , respectively, by LECO method.

(d) 0.029 and 0.024 , respectively, by LECO method. 
TABLE 10. Concentration Ranges for Radioactive Isotopes in Point Beach (PWR) Spent

Fuel Pool water, May 1979

\begin{tabular}{|c|c|}
\hline Isotope & Concentration, $\mu_{\mathrm{C}} \mathrm{i} / \mathrm{ml}$ \\
\hline${ }^{57} \mathrm{Co}$ & $1 \times 10^{-5}$ to $9 \times 10^{-6}$ \\
\hline${ }^{144} \mathrm{Ce}$ & $2 \times 10^{-4}$ to $5 \times 10^{-6}$ \\
\hline${ }^{51} \mathrm{Cr}$ & $7 \times 10^{-5}$ \\
\hline${ }^{103} \mathrm{Ru}$ & $1 \times 10^{-5}$ \\
\hline${ }^{134} \mathrm{Cs}$ & $3 \times 10^{-4}$ to $2 \times 10^{-5}$ \\
\hline${ }^{137} \mathrm{Cs}$ & $3 \times 10^{-4}$ to $2 \times 10^{-5}$ \\
\hline${ }^{95} \mathrm{Zr}$ & $6 \times 10^{-5}$ to $2 \times 10^{-5}$ \\
\hline${ }^{95} \mathrm{Nb}$ & $1 \times 10^{-4}$ to $3 \times 10^{-5}$ \\
\hline $58 \mathrm{Co}$ & $6 \times 10^{-4}$ to $4 \times 10^{-4}$ \\
\hline${ }^{54} \mathrm{Mn}$ & $1 \times 10^{-4}$ to $1 \times 10^{-5}$ \\
\hline${ }^{60} \mathrm{Co}$ & $2 \times 10^{-3}$ to $7 \times 10^{-4}$ \\
\hline${ }^{141} \mathrm{Cs}$ & $5 \times 10^{-6}$ \\
\hline${ }^{125} \mathrm{Sb}$ & $2 \times 10^{-5}$ to $7 \times 10^{-6}$ \\
\hline
\end{tabular}

The weld microstructure suggests that the weld was made with a single pass. The depth of penetration into the parent metal was not excessive.

The nut and washer formed several crevice areas. Figure 21 shows a cross section of the thread area of the nut. Although some mechanical working can be seen, no corrosion is evident. The washer has three crevice areas: between the nut and washer, the washer and bolt, and the washer and rack brace (see Figure 22). Although the washer surface in contact with the nut is scratched and gouged, no significant attack or corrosion was observed even in the damaged area. This is also the case between the washer and bolt.

A mild (up to 16-um) grain boundary penetration was observed between the washer and rack brace.

SUMMARY AND CONCLUSIONS - POINT BEACH

Four rack section welds, a nut, and washer were examined after $6.7 \mathrm{yr}$ in the Point Beach (PWR) fuel storage pool. No significant attack or corrosion 

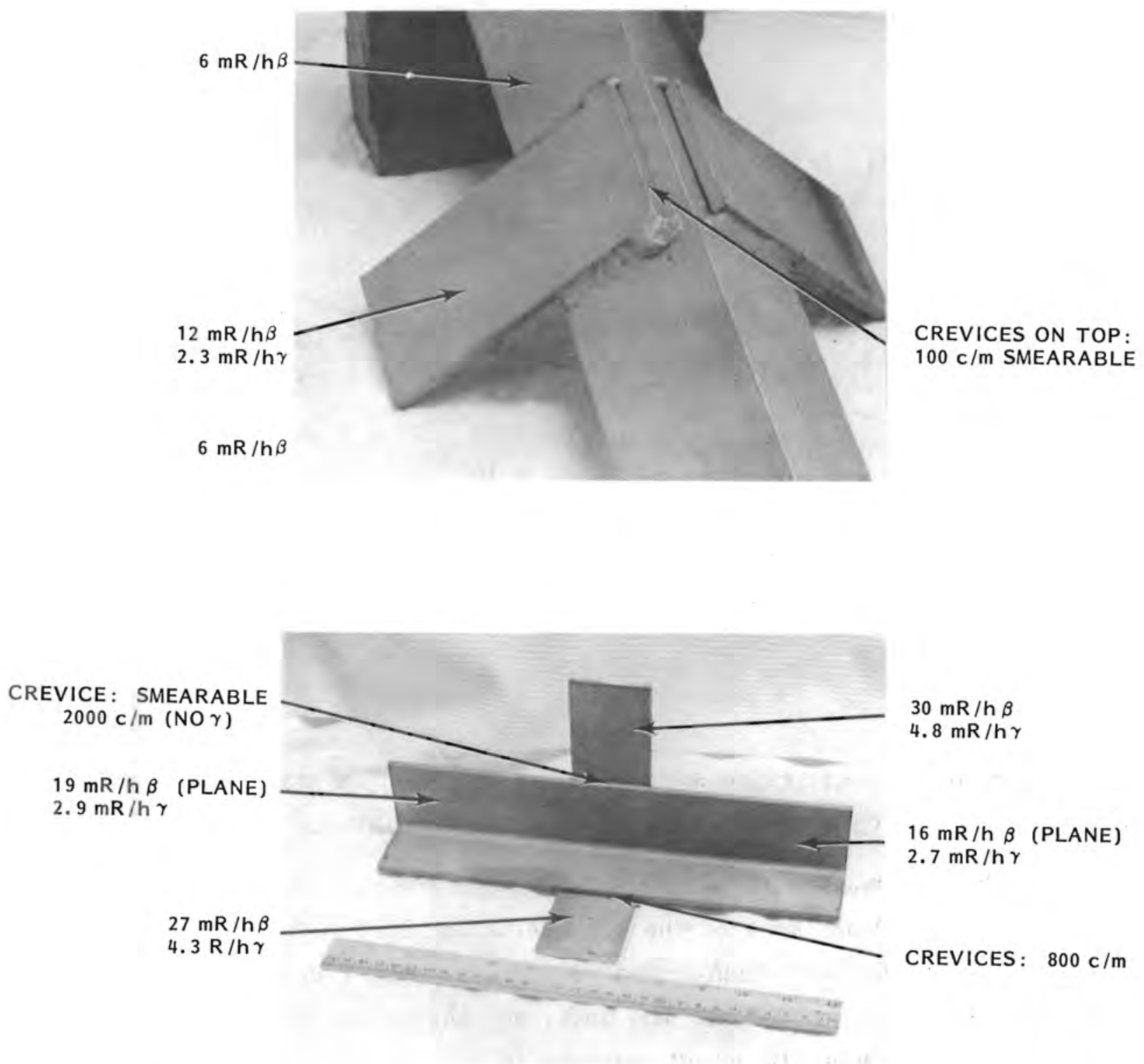

FIGURE 17. Radioactivity Distribution of Point Beach Rack Section (304 SS)

was observed. Some grain boundary penetration was observed on the washer, but it was mild $(<16 \mu \mathrm{m})$. The structural integrity of each component did not appear to be significantly changed during pool residence. 


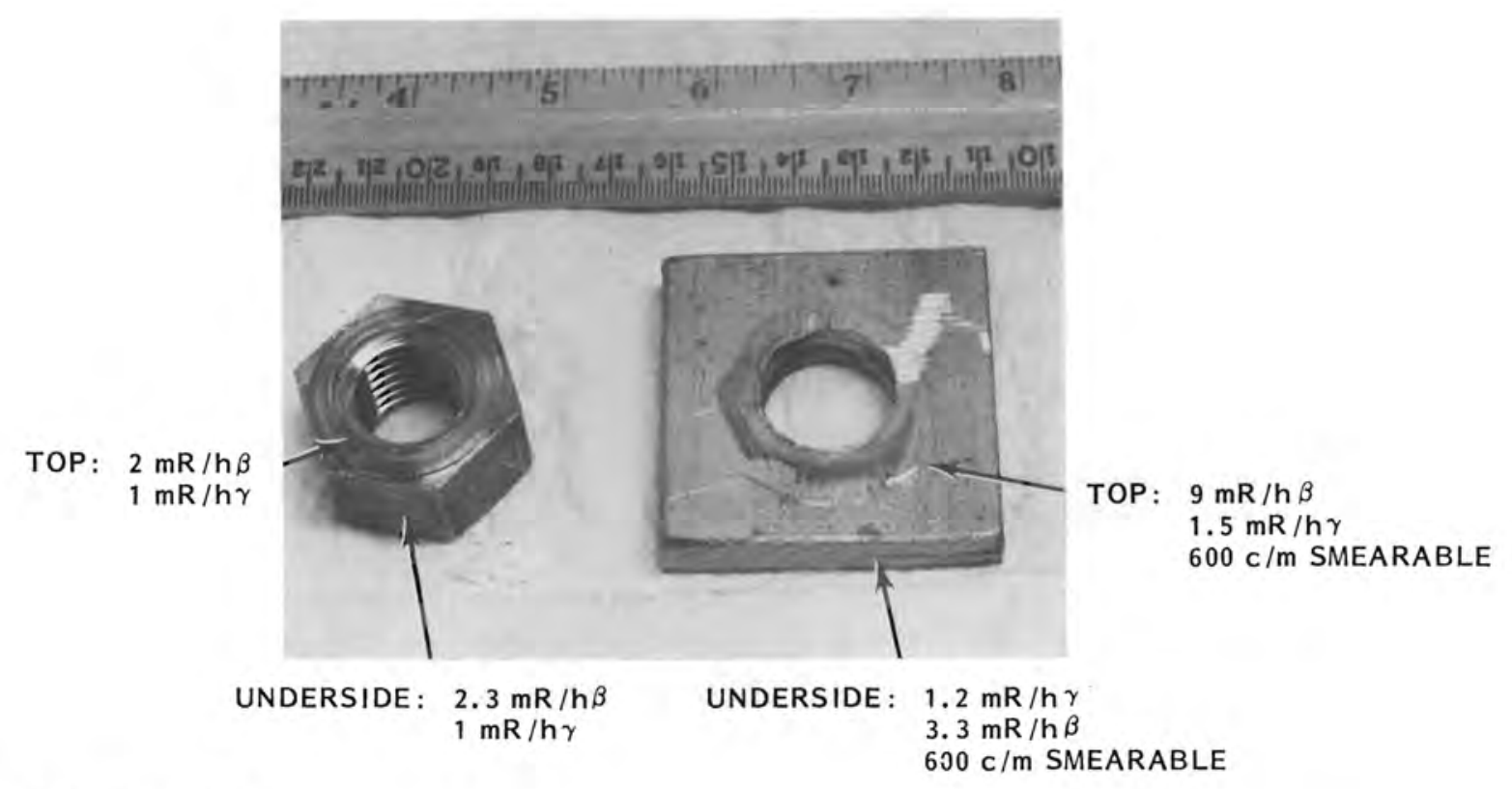

Neg. 790465-5

FIGURE 18. Radioactivity Distribution of Point Beach Nut and Washer (304 SS) 


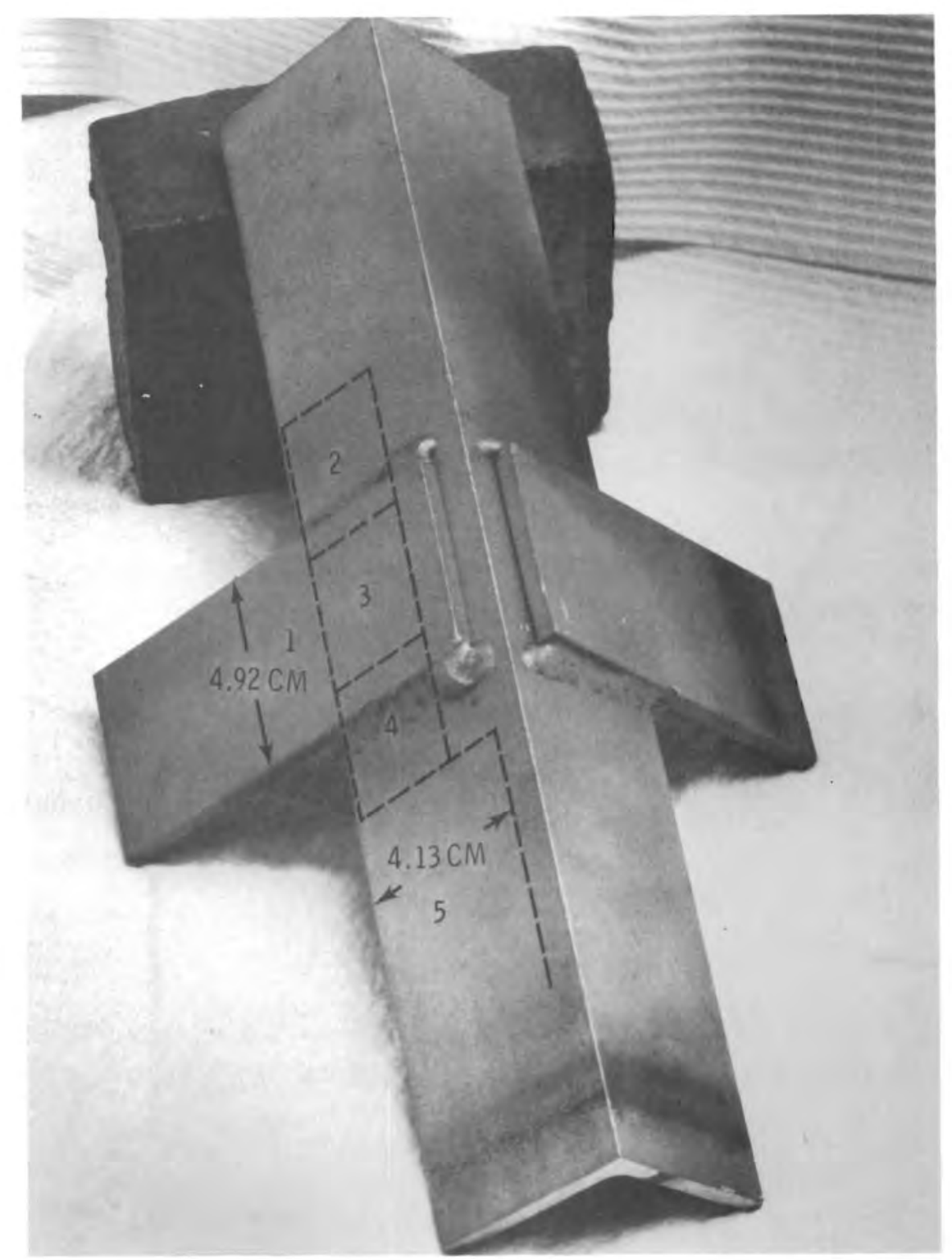

Neg. 81F573-1

FIGURE 19. Fuel Storage Rack from Point Beach (PWR) Spent Fuel Pool (304 SS, $0.05 \mathrm{wt} \% \mathrm{C}$ ). Exposed to $2000-\mathrm{ppm} \mathrm{B}$ as boric acid for $6.7 \mathrm{yr}$ at 16 to $45^{\circ} \mathrm{C}$. 


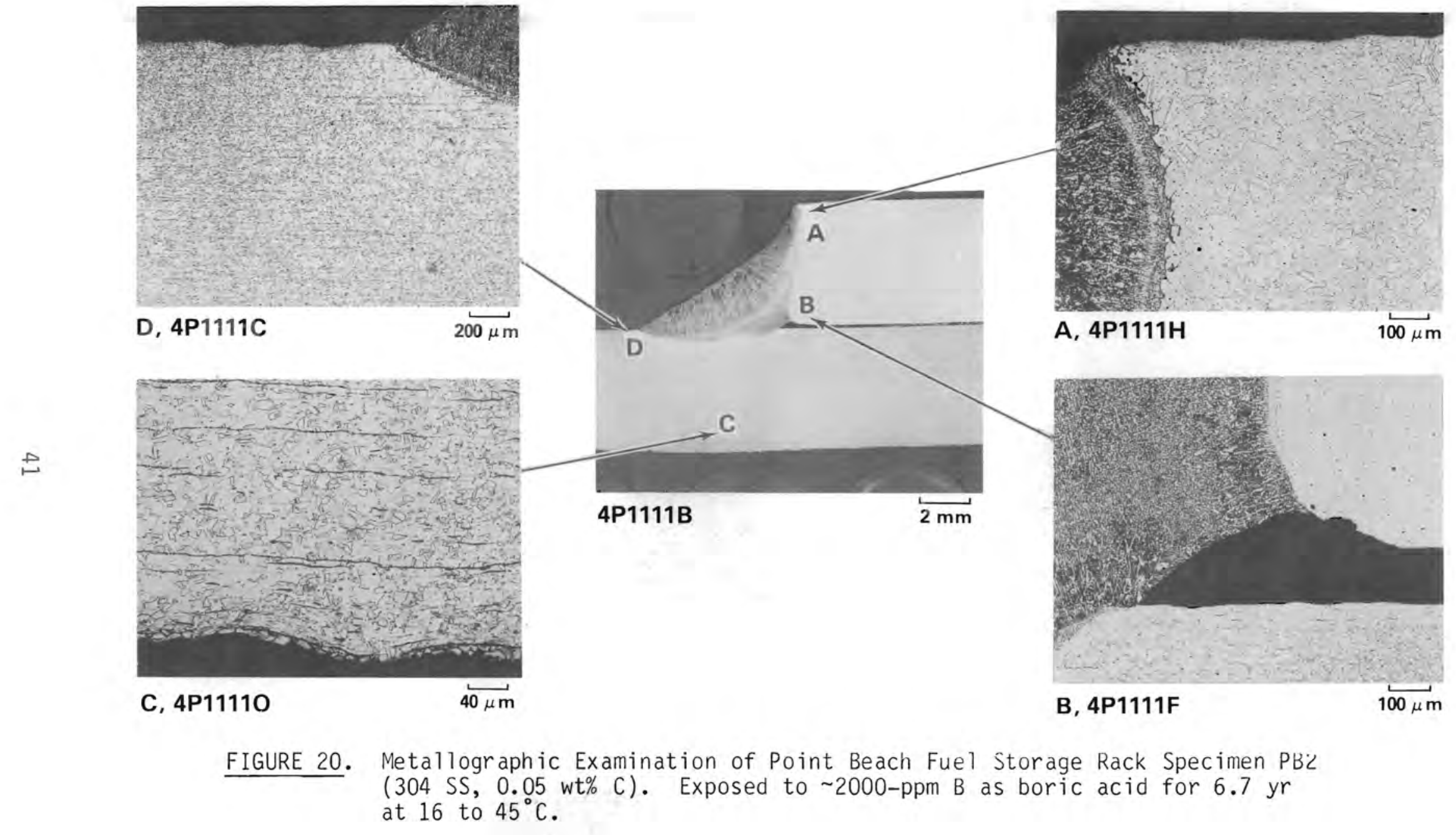



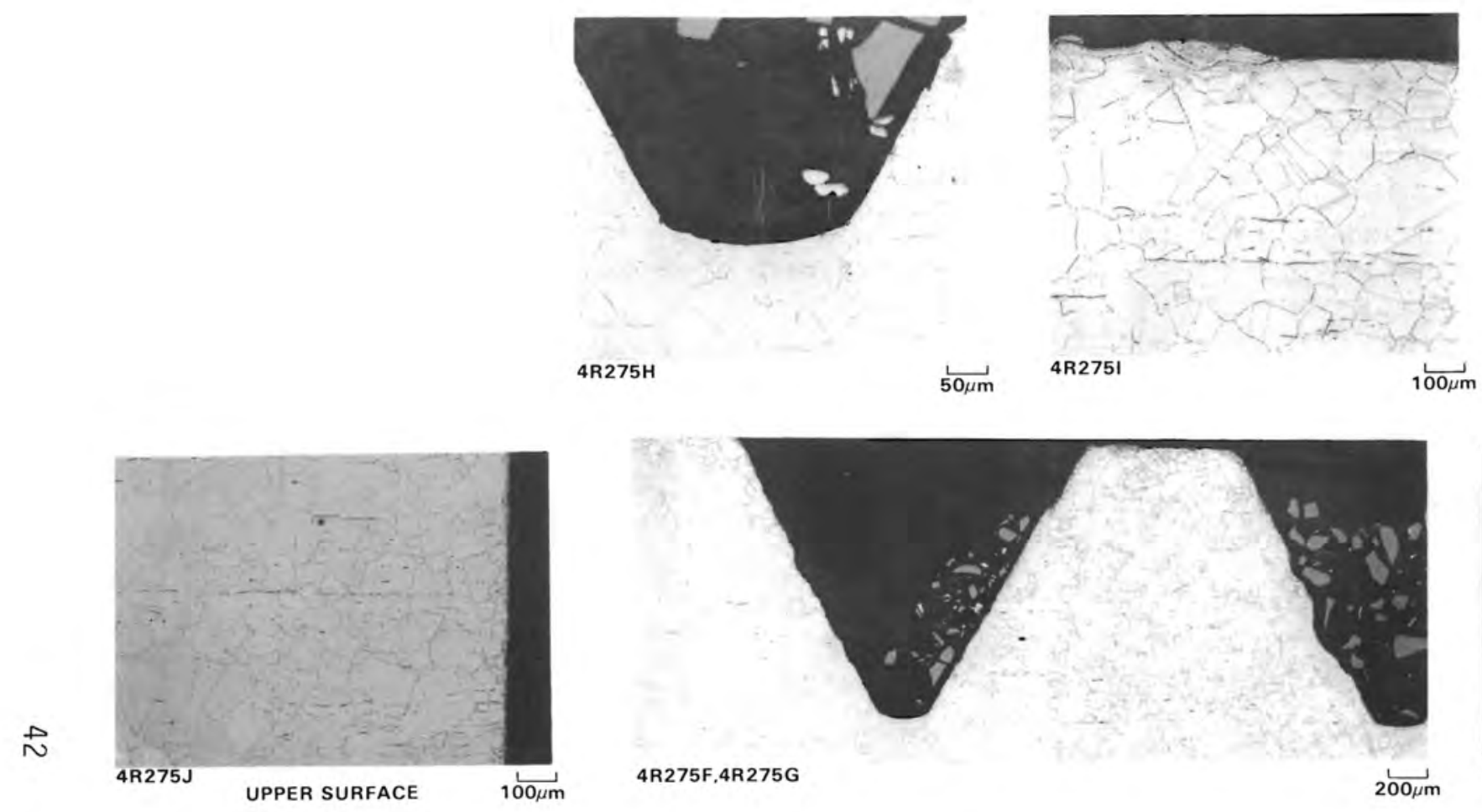

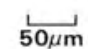

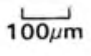
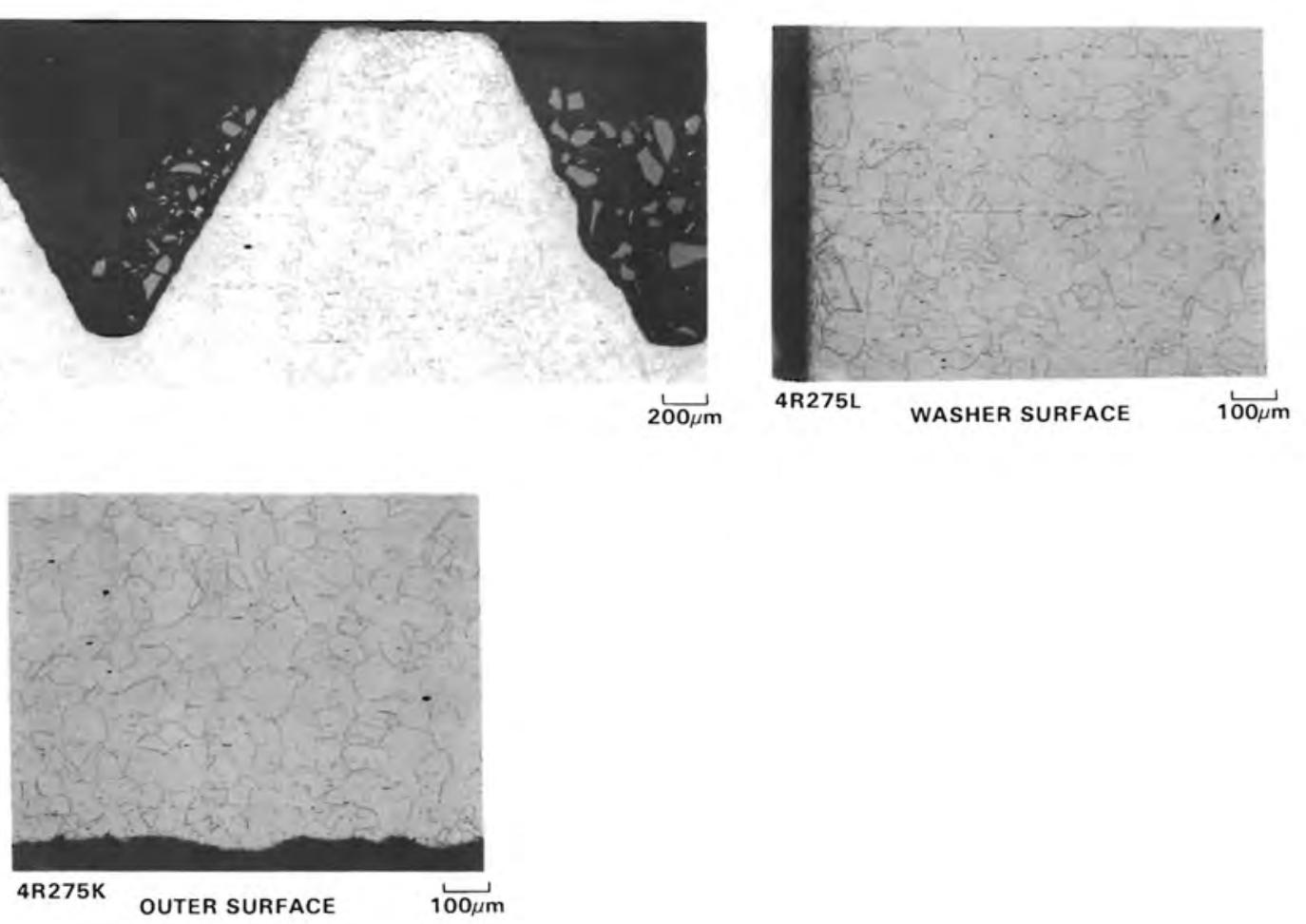

FIGURE 21. Metallographic Examination of Point Beach Fuel Rack Nut (304 SS). Exposed to 2000-ppm B as boric acid for $6.7 \mathrm{yr}$ at 16 to $45^{\circ} \mathrm{C}$. 

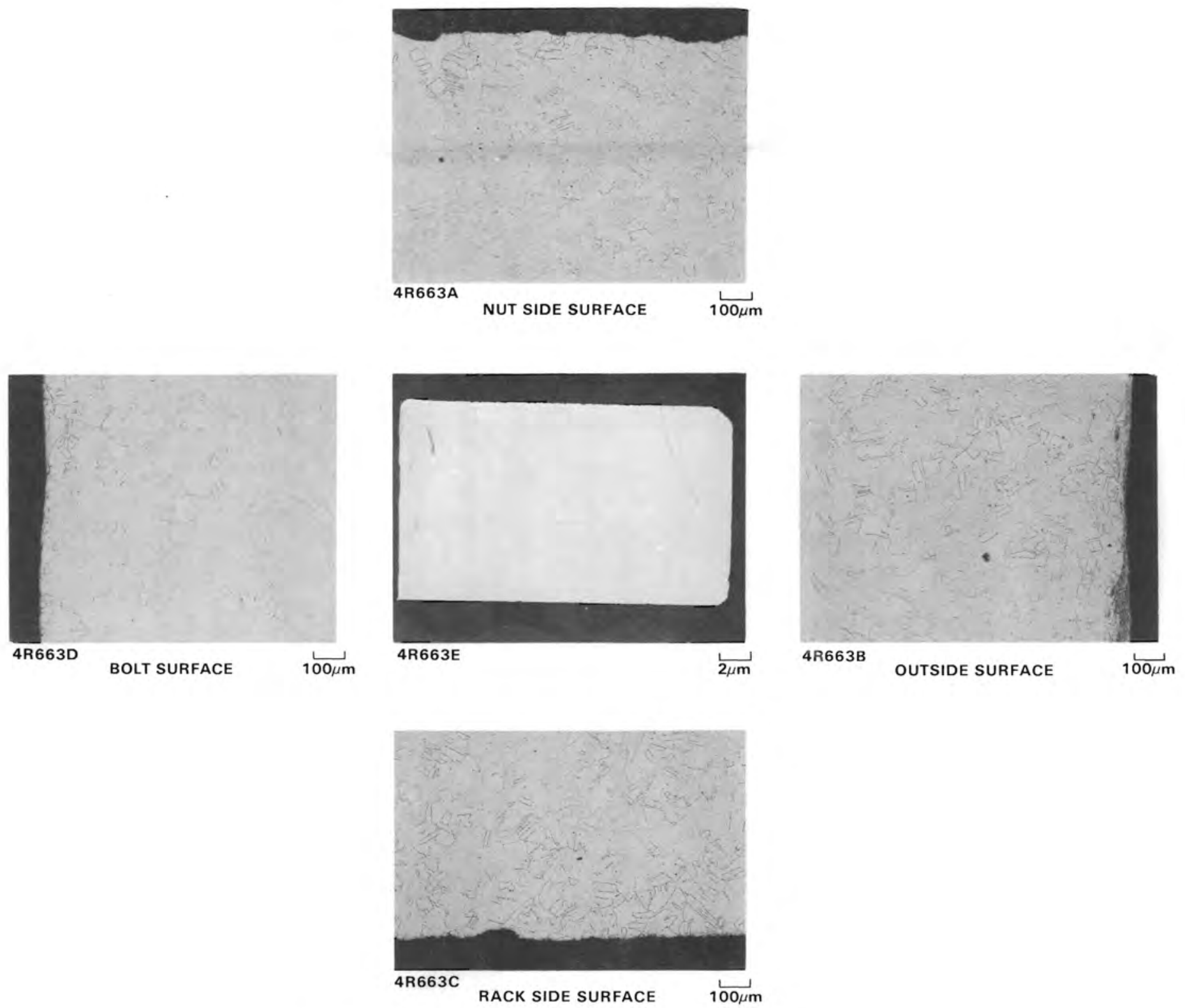

FIGURE 22. Metallographic Examination of Point Beach Fuel Rack Washer (304 SS). Exposed to 2000-ppm B as boric acid for $6.7 \mathrm{yr}$ at 16 to $45^{\circ} \mathrm{C}$ 


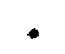




\section{EXAMINATION OF ZION (PWR) SPENT FUEL POOL RACK SECTIONS}

Three sections of a 304 SS SFP rack from the Zion Nuclear Power Station (Zion, Illinois) were received at PNL for examination in December 1980. The three sections were cut from the upper edge of one rack. Figure 23 shows the location of the rack with in the SFP, and Figure 24 shows one of the sections as it was received at PNL.

Section 2 (see Figure 23) was decontaminated by electropolishing, which was performed at PNL and sponsored by Quadrex Corporation. An electropolished specimen was subjected to metallographic examination; all other examinations were performed on as-received rack sections.

Each section exhibited an untarnished surface with some discoloration at the welds. The inside (fuel-side) surfaces (shown in Figure 25) were covered with a brown deposit that became thinner toward the top of the fuel storage cel1. The deposit could be wiped off to reveal an untarnished surface similar to the outside of the sections.

Rack component specimens were decontaminated by electropolishing and analyzed by emission spectrometry. Results of the elemental analysis are presented in Table 11. The rack was exposed to pool water for approximately $4.8 \mathrm{yr}$ (early 1976 to November 5, 1980). Pool chemistries and conditions are shown in Table 11.

\section{ZION RADIOACTIVITY ANAL YSIS}

Radiation readings for two of the sections were taken as the sections were unpacked. The section sent for decontamination was 10,000 - to $23,000-\mathrm{cpm} \mathrm{B} / \mathrm{r}$ on inside (fuel-side) surfaces with 1,500-dpm $\alpha$. The corresponding readings on the outside surface were 5,000-cpm $\beta / \gamma$ and $<200-d p m \alpha$. After decontamination by electropolishing, inside and outside readings were below $200-c \mathrm{pm} \beta / \gamma$ and <200-dpm a. During electropolishing, less than 1 mil of metal was removed.

The as-received rack section used for microstructural analys is had $75,000-c p m \beta / \gamma$ and 300-dpm $\alpha$ on inside surfaces and 5,000-cpm $\beta / \gamma$ and $<200-d p m a$ on outside surfaces. 


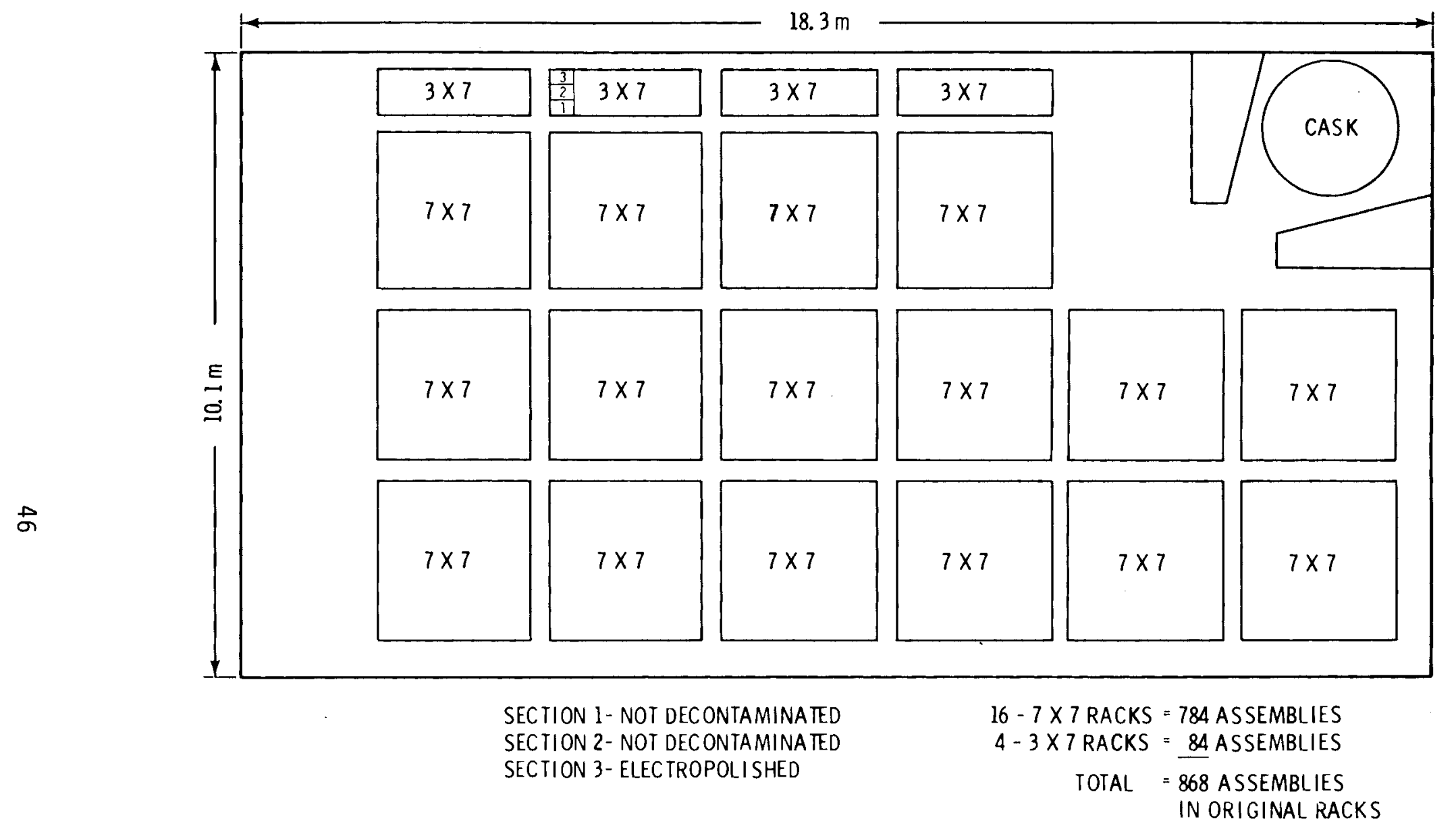

FIGURE 23. Zion Spent Fuel Pool Arrangement. Replacement racks have storage locations for 2112 assemblies as compared to 868 assemblies for original racks. 


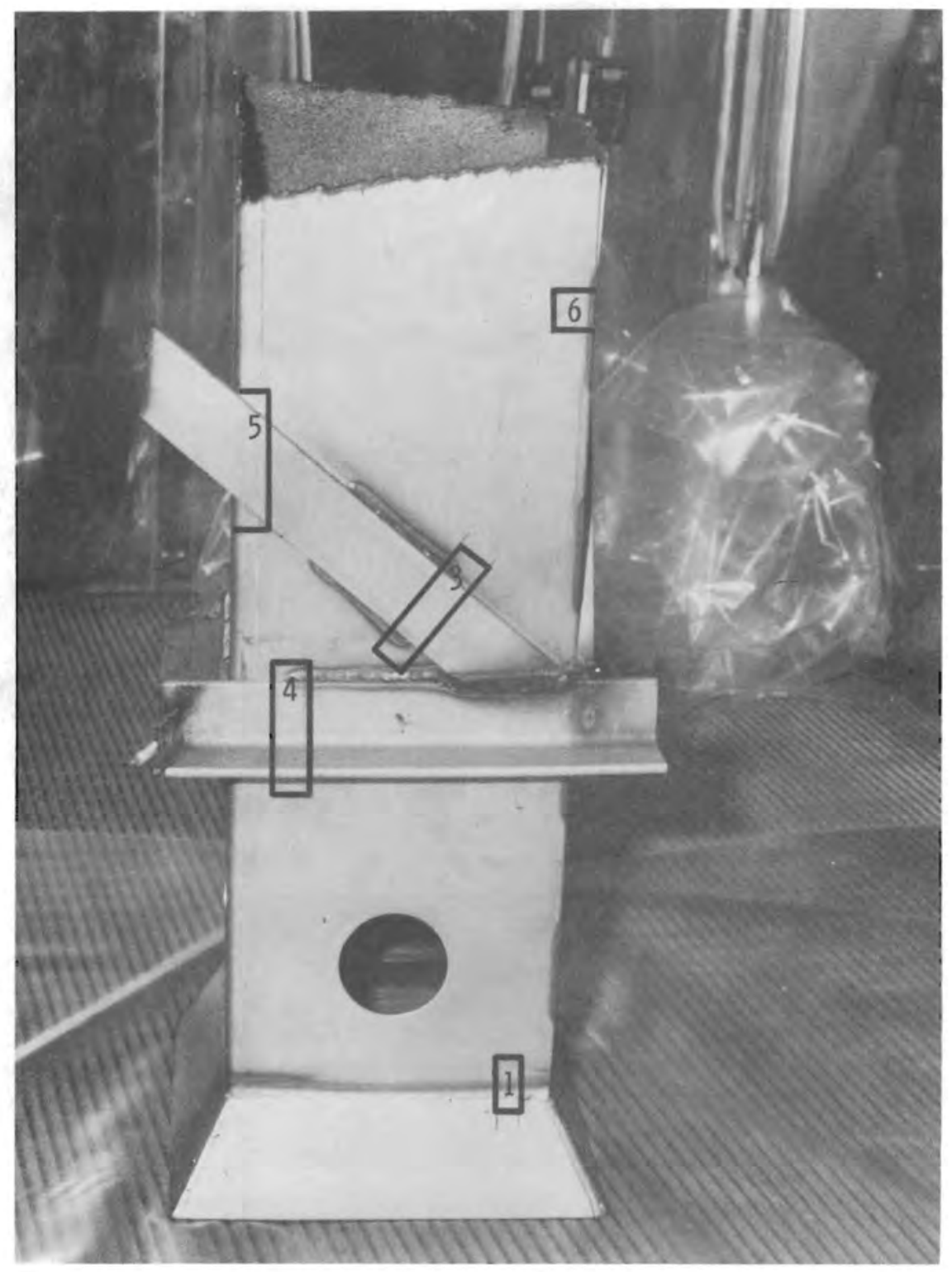

Neg. 81F373-3

FIGURE 24. Fuel Storage Rack Section from Zion (PWR) Spent Fuel Pool (304 SS). A complete module of the type shown above accommodates a PWR fuel assembly for storage. Exposed to 2000- to 4000-ppm B as boric acid for $4.8 \mathrm{yr}$ at 21 to $27^{\circ} \mathrm{C}$. 


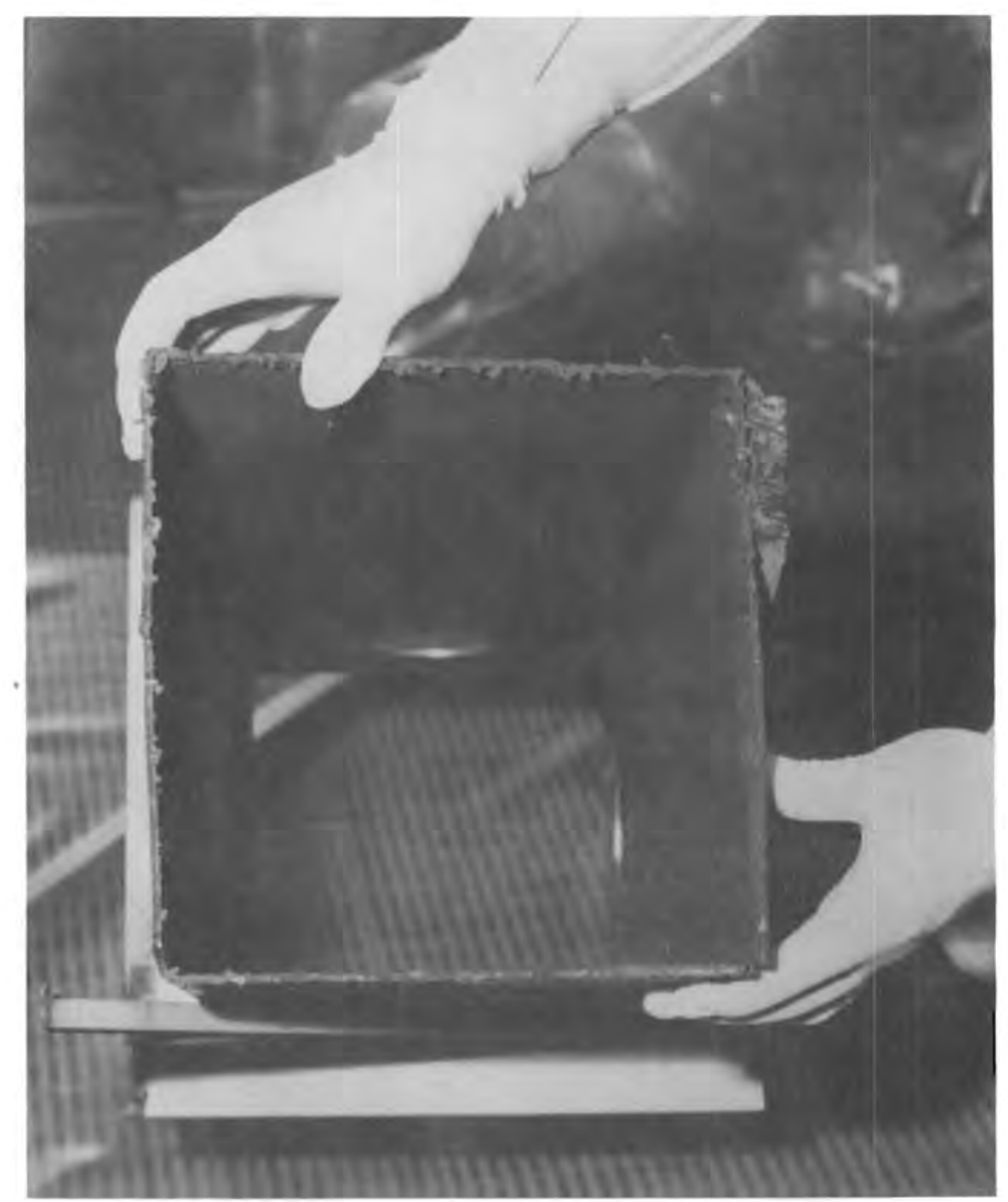

Neg. 81F573-2

FIGURE 25. Inside of Fuel Storage Rack Section from Zion (PWR) Spent Fuel Pool (304 SS, 0.06\% C). Exposed to 2000- to $4000-p p m B$ as boric acid for 4.8 yr at 21 to $27^{\circ} \mathrm{C}$.

\section{ZION MICROSTRUCTURAL ANALYSIS}

Ten welds on one rack section were visually examined; four of these welds were examined metallographically. One metallographic sample was also examined by SEM and Auger spectrometry. A total of 17 welds were examined visually. None of the welds examined visually showed signs of degradation or corrosion, and all appeared structurally sound. 
TABLE 11. Rack Specimen Compositions and Pool Conditions(a) for Zion Spent Fuel 304 SS Rack

\begin{tabular}{|c|c|c|c|c|c|c|c|c|c|c|c|c|c|c|c|}
\hline \multirow[b]{2}{*}{ Heat } & \multirow[b]{2}{*}{ Material } & \multicolumn{14}{|c|}{ Rack Specimen Composition, (b) wt\% } \\
\hline & & $c^{(c)}$ & $\mathrm{Mn}$ & $\mathrm{P}$ & $s^{(c)}$ & Si & $\mathrm{Ni}$ & $\mathrm{Cr}$ & Mo & V & $\mathrm{Cu}$ & $\mathrm{Sn}$ & $\mathrm{Al}$ & $\mathrm{Ti}$ & $\mathrm{Co}$ \\
\hline 210 & 304 SS & 0.048 & & & 0.012 & & & & & & & & & & \\
\hline $23 B$ & 304 SS & 0.058 & 1.57 & 0.031 & 0.013 & 0.50 & 8.36 & 18.25 & 0.46 & 0.040 & 0.20 & 0.019 & 0.010 & 0.006 & 0.122 \\
\hline Z30 & 304 SS & 0.057 & 0.48 & 0.020 & 0.010 & 0.54 & 8.15 & 18.73 & 0.39 & 0.028 & 0.19 & 0.013 & 0.016 & 0.007 & 0.094 \\
\hline $25 B$ & 304 SS & 0.059 & 1.61 & 0.031 & 0.019 & 0.93 & 8.89 & 18.80 & 0.48 & 0.032 & 0.14 & 0.013 & $0.00 y$ & 0.005 & 0.163 \\
\hline
\end{tabular}

(a) Pool Conditions

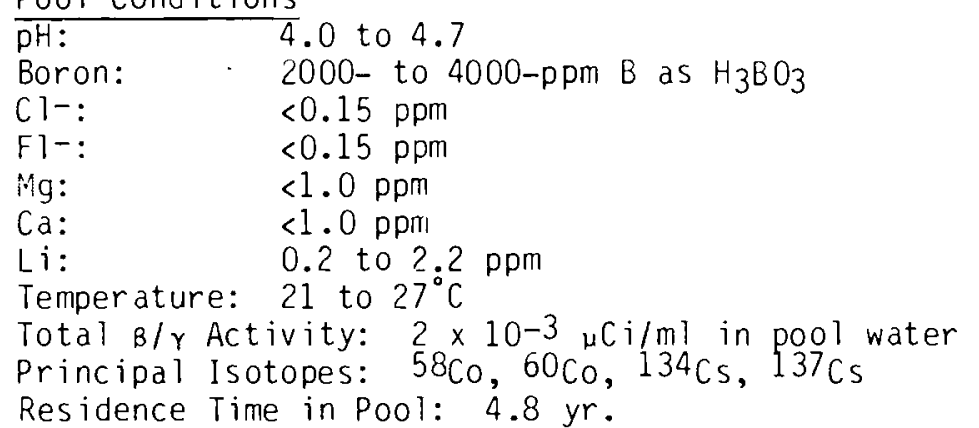

(b) Analys is performed by Jorgensen Steel Co., Seattle, Washington.

(c) Performed by LECO method. 
Figure 26 shows one of the four welds examined by optical metallography and is representative of the other welds examined, Oxide films were too thin to resolve. Minor pitting in the crevice between the brace and the section wall did not exceed $20 \mu \mathrm{m}$ in over $4.8 \mathrm{yr}$ and was observed only in the brace metal. The differing microstructure of the brace (Z51B) suggests possible sensitization. Despite this, the pitting attack was well within the corrosion rates reported for stainless steel in dilute boric acid environments. (24) Some grain boundary widening at the metal/water interface is seen, but it is less than $10 \mu \mathrm{m}$ in the worst case. The grain boundary widening is seen on the inside of the rack wall and is not seen to be a function of distance from welds or the amount of deposit. This widening may have been related to the manufacturing of the rack rather than to a corrosion process during service. Some dark grain boundaries seen near the weld in sample 1B (see figure 27) were analyzed by SEM-EDAX and Auger techniques. SEM-EDAX studies showed that the grain boundaries were eroded and free of contaminants. Auger analysis confirmed the SEM-EDAX analysis and indicated that the grain boundary material was identical to the weld material with the oxygen concentration in both being the same. This weld material penetrates down the grain boundaries during the welding process.

SUMMARY AND CONCLUSIONS - ZION

Ten welds from a rack section exposed for $4.8 \mathrm{yr}$ in the Zion (PWR) Nuclear Power Plant SFP (>2000-ppm B) were visually examined, and four welds were examined metallographically. No atypical welds or evidence of excessive welding temperature were observed; all welds appeared to be structurally sound. Some minor corrosion (<20 $\mu \mathrm{m}$ in depth) was detected in the crevice between the brace and the section wall.

For a service exposure of $4.8 \mathrm{yr}$, the rack sections were in extremely good condition. There appeared to be no significant corrosion or degradation problems; the integrity of the components appeared to be unchanged from preservice conditions. 

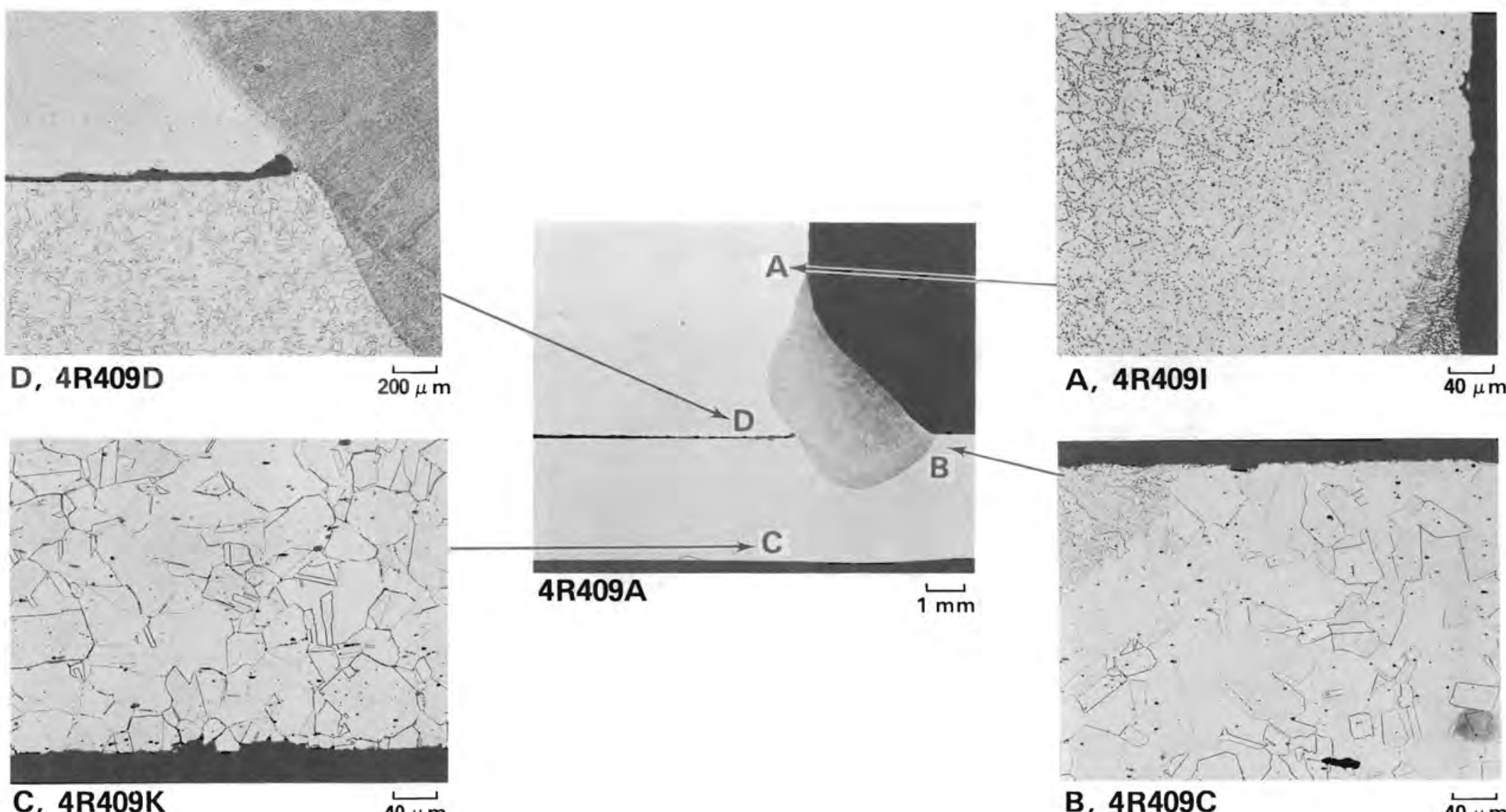

C, 4R409K

$4 \longdiv { 4 0 \mathrm { m } }$

B, 4R409C

$\overleftarrow{40 \mu \mathrm{m}}$

FIGURE 26. Metallographic Examination of Zion Sample 4B (304 SS 0.06\% C). Exposed to 2000- to 4000-ppm B as boric acid for 4.8 yr at 21 to $27^{\circ} \mathrm{C}$. 


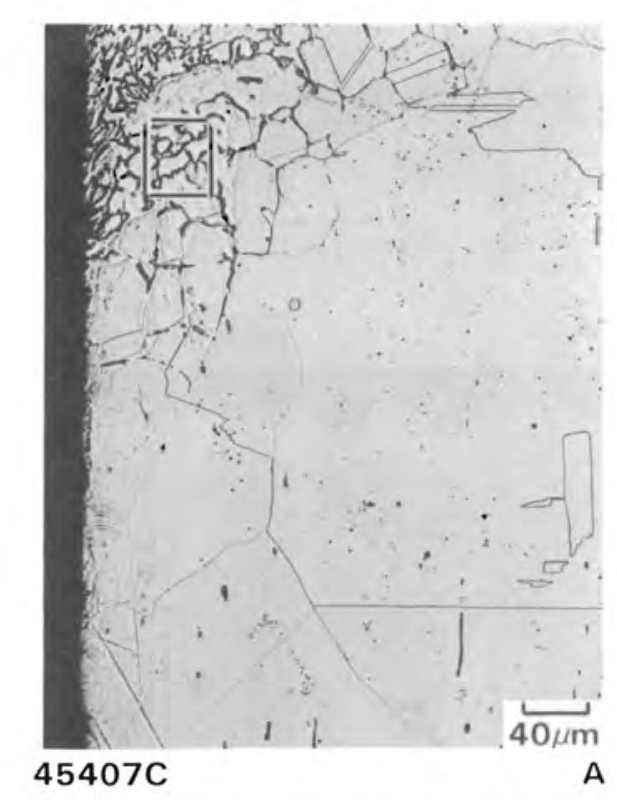

U

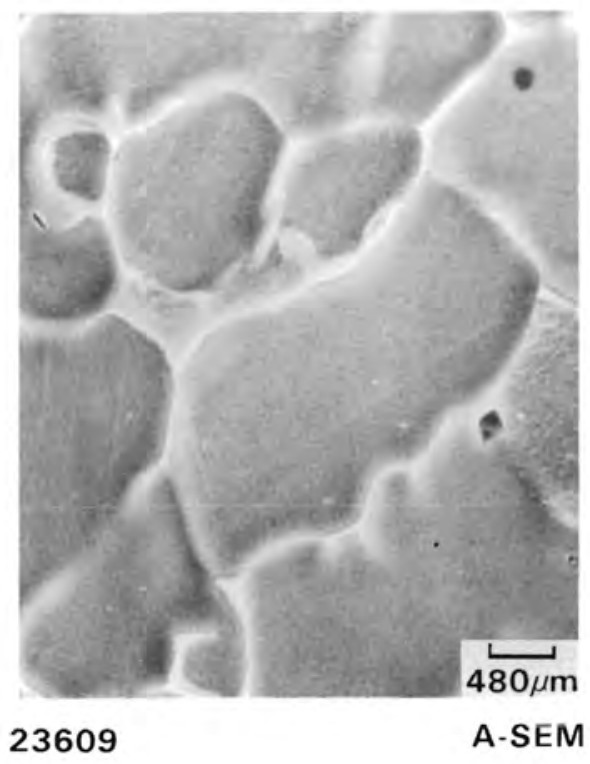

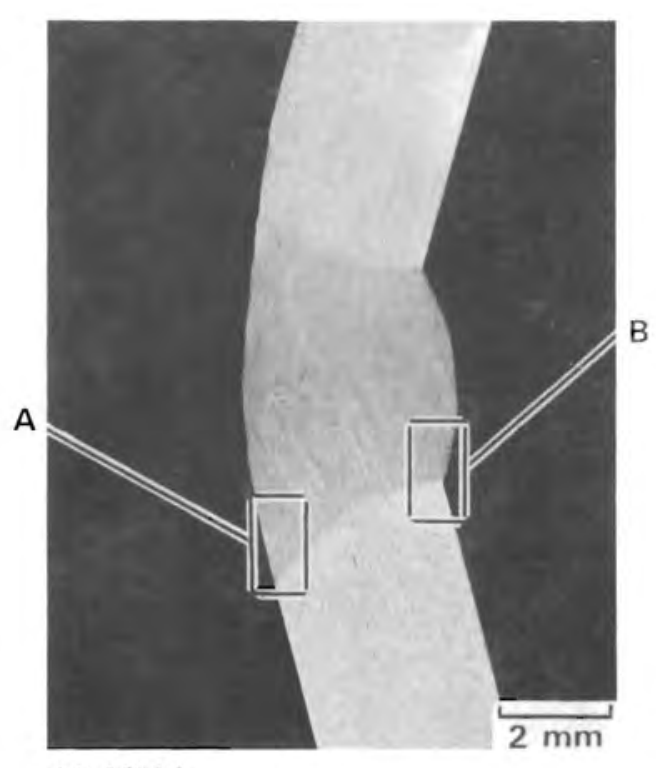

4R407A

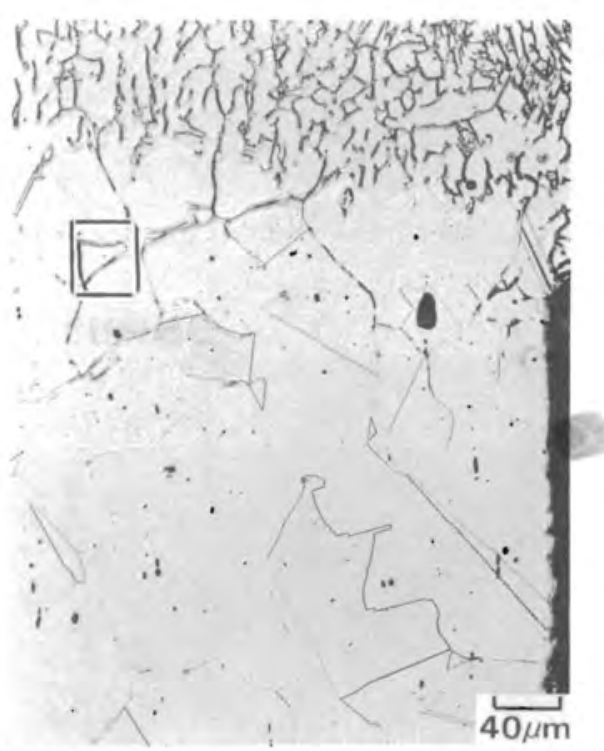

4R407E

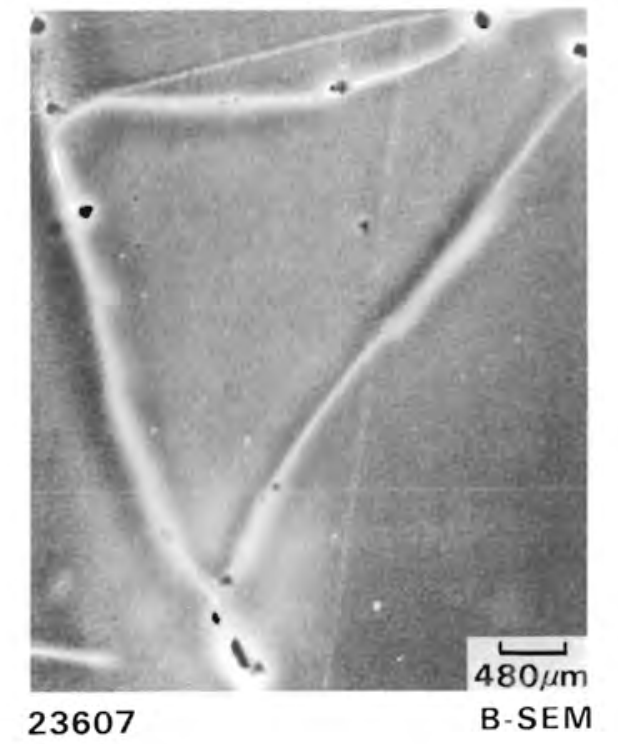

FIGURE 27. SEM Examination of Zion Sample 1B (304 SS). Exposed to 2000- to 4000-ppm B as boric acid for 4.8 yr at 21 to $27^{\circ} \mathrm{C}$. 


\section{EXAMINATION OF LA CROSSE (BWR) SPENT FUEL STORAGE RACK SECTIONS}

In April 1981 PNL received from Dairyland Power Cooperative's LACBWR Power Plant (La Crosse, Wisconsin) ten sections taken from the two types of SFP racks used at that facility. The older rack consisted of 304 SS with a 6.35-mm (1/4-in.) boronated SS plate. ( $\geq 2 \mathrm{wt} \%$ B) between every other assembly. The newer rack used 304 SS with a boral sandwich (35 wt\% $B_{4} C$ dispersion between 1.04-mm Type 1100 aluminum sheets) on the outside faces. An elemental analys is of each material is given in Table 12 .

The boronated SS rack was used for temporary storage from December 1968 to August 1972 when continuous storage of spent fuel was initiated. The new boral racks were placed in the pool in December 1976. Both types of racks were removed from the pool during reracking in July 1980. The racks were thus exposed to pool water for 11.5 and $3.5 \mathrm{yr}$, respectively.

Table 13 shows the pool chemistry and conditions that existed in the SFP and concentration ranges of radioactive isotopes in the pool water.

A visual inspection of the sections showed that the surfaces were generally untarnished with discoloration at the weld ranging from metallic to golden to black. No weld spattering was observed, suggesting that normal weld procedures were used. A brown deposit was present on the inner surfaces but could be easily removed to reveal a surface similar to the outer surfaces. All 36 welds that were examined on the La Crosse specimens appeared to be structuraliy sound.

\section{LA CROSSE RADIOACTIVITY ANALYSIS}

Data received from LACBWR indicated the activities and principal isotopes that were present. These data are summarized in Table 14 for samples L4, L9, and L10.

The activity was associated with the brown deposit and was smearable. 
TABLE 12. Rack Specimen Compositions and Pool Conditions(a) for La Crosse Spent Fuel Storage Racks(b)

\begin{tabular}{|c|c|c|c|c|c|c|c|c|c|c|c|}
\hline \multirow[b]{2}{*}{ Heat } & \multirow[b]{2}{*}{ Material } & \multicolumn{10}{|c|}{ Rack Specimen Composition, (b) wt\% } \\
\hline & & $C$ & $M n$ & $P$ & $\mathrm{~S}$ & $\mathrm{Si}$ & $\mathrm{Ni}$ & $\mathrm{Cr}$ & Mo & $\mathrm{Cu}$ & $\mathrm{Co}$ \\
\hline$A C 1$ & 304 SS & $<0.060$ & 1.52 & 0.020 & 0.12 & 0.65 & 9.10 & 18.36 & 0.24 & 0.23 & 0.06 \\
\hline$A C 2$ & Borated SS & 0.045 & 1.52 & 0.019 & 0.020 & 0.57 & 9.43 & 18.93 & & & \\
\hline NES & 304 SS & 0.046 & 1.23 & 0.027 & 0.011 & 0.42 & 8.27 & 18.05 & 0.21 & 0.09 & 0.22 \\
\hline NES & Boral & & 1 & 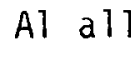 & with & $5 \% \mathrm{~B}_{4} \mathrm{C}$ & & by & $h$ ht & & \\
\hline
\end{tabular}

(a) Pool Conditions

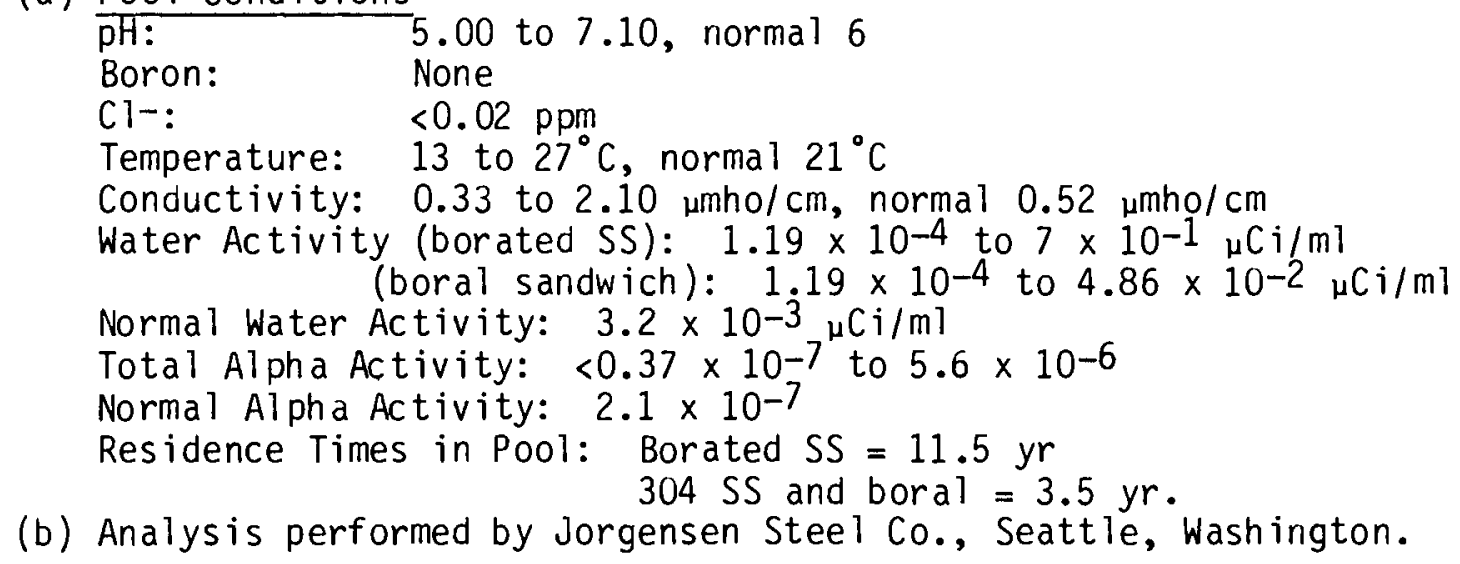


TABLE 13. Concentration Ranges for Radioactive Isotopes in La Crosse (BWR) Spent Fuel Pool Water

\begin{tabular}{|c|c|}
\hline Isotope & Concentration, $\mu \mathrm{C} i / \mathrm{ml}$ \\
\hline$\overline{58 \mathrm{Co}}$ & $9.30 \times 10^{-4}$ \\
\hline${ }^{60} \mathrm{Co}$ & $1.7 \times 10^{-4}, 4 \times 10^{-5(a)}$ \\
\hline${ }^{99} \mathrm{Tc}$ & $8.8 \times 10^{-4}$ \\
\hline $131_{I}$ & $2.7 \times 10^{-3}$ \\
\hline $133 \mathrm{xe}$ & $4.9 \times 10^{-3}$ \\
\hline${ }^{134} \mathrm{Cs}$ & $2.5 \times 10^{-3}, 1 \times 10^{-4(a)}$ \\
\hline${ }^{137} \mathrm{Cs}$ & $3.9 \times 10^{-3}, 3 \times 10^{-3(a)}$ \\
\hline
\end{tabular}

(a) Readings taken in August 1979; all others taken during refueling outage in 1977.

TABLE 14. Radioactivity Measured on Surfaces of La Crosse Spent Fuel Storage Rack Specimens in Early 1981

\begin{tabular}{|c|c|c|c|c|c|c|c|}
\hline Type of & & & Rack & urface & Activ & $\mathrm{s}, \mathrm{H}$ & \\
\hline Specimen & Sample & ${ }^{137} \mathrm{Cs}$ & ${ }^{134} \mathrm{Cs}$ & ${ }^{60} \mathrm{CO}_{\mathrm{O}}$ & ${ }^{57} \mathrm{Co}$ & ${ }^{144} \mathrm{Ce}$ & ${ }^{54} \mathrm{Mn}$ \\
\hline $\begin{array}{l}\text { SS/SS Borated } \\
\text { Steel }\end{array}$ & L4 & 2.16 & 0.20 & 0.31 & 0.007 & 0.07 & - \\
\hline Boral & L9 & 0.04 & 0.00 & 0.30 & 0.001 & 0.01 & 0.002 \\
\hline SS/SS & L10 & 13.43 & 1.96 & 1.04 & 0.050 & 1.54 & 0.017 \\
\hline
\end{tabular}

\section{LA CROSSE METALLOGRAPHIC ANALYSIS}

Two representative specimens with a total of four welds and a section of boral plate were metallographically examined.

Sample L4 was taken from the older rack about halfway up and on the end of the rack and had been exposed to pool conditions for $11.5 \mathrm{yr}$. Samples $L 9$ and L10 were taken from the new rack that had been exposed to pool conditions for $3.5 \mathrm{yr}$. Sample L9, the boral plate, was taken from the center region of the rack, while sample L10 was taken from the middle of the top edge of the rack. 
Sample $L 4$ is shown in Figure 28 and consists of boronated stainless steel welded to 304 SS welded to another 304 SS plate. Figure 29 shows the micrographs of sample L4. No evidence of significant intergranular attack or other degradation can be seen. The microstructure of each plate indicated similar processing histories. The boral plate, sample L9, is shown in Figure 30 while Figure 31 shows the micrographs of the cross section. The boral plate was difficult to polish due to $\mathrm{B}_{4} \mathrm{C}$ pullout. Although scratched and dented, a uniform 6-um oxide layer covered the aluminum-clad surface. No evidence of other types of corrosion could be seen on the aluminum.

Figure 32 shows a view of specimen L10; Figure 33 shows metallographic sections of the specimen. No intergranular attack or other degradation is evident.

\section{SUMMARY AND CONCLUSIONS - LA CROSSE}

A total of 36 welds and two boral plates from Dairyland Power Cooperative's LACBWR Nuclear Power Plant were examined visually; five welds and a section of boral plate were examined metallographically. Exposure time was 3.5 to $11.5 \mathrm{yr}$. All welds were structurally sound, and none were atypical. No evidence of significant intergranular attack or corrosion was found. The integrity of the components did not appear to be significantly degraded by pool residence. 


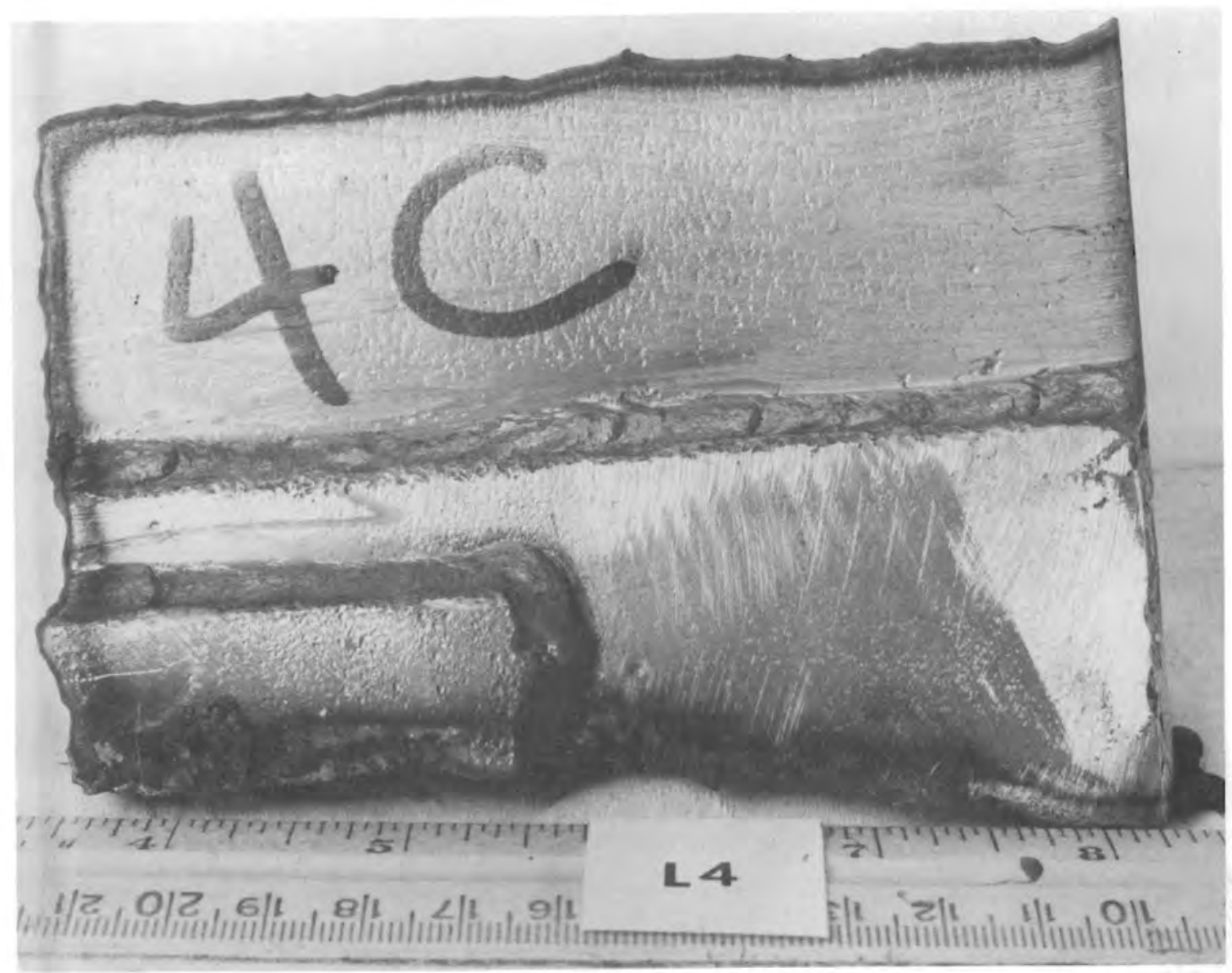

Neg. 810321-8-7

FIGURE 28. La Crosse (BWR) Fuel Storage Rack Specimen L4C (304 SS, $<0.06 \%$ C). Exposed to deionized water for $11.5 \mathrm{yr}$ at 13 to $27^{\circ} \mathrm{C}$. 

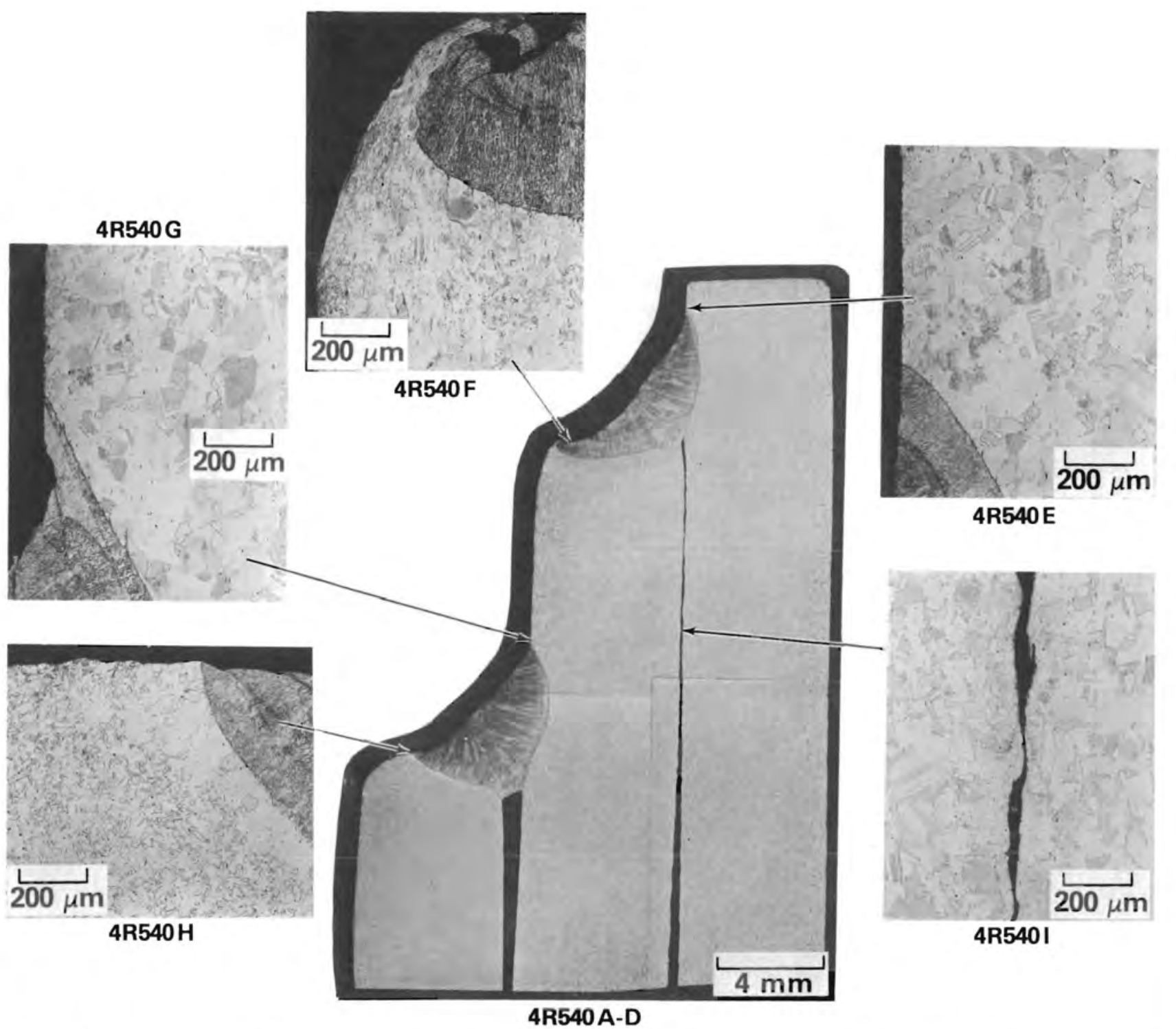

FIGURE 29. Metallographic Examination of La Crosse (BWR) Fuel Storage Rack Specimen L4C (304 SS, $<0.06 \% \mathrm{C})$. Exposed to deionized water for $11.5 \mathrm{yr}$ at 13 to $27^{\circ} \mathrm{C}$. 


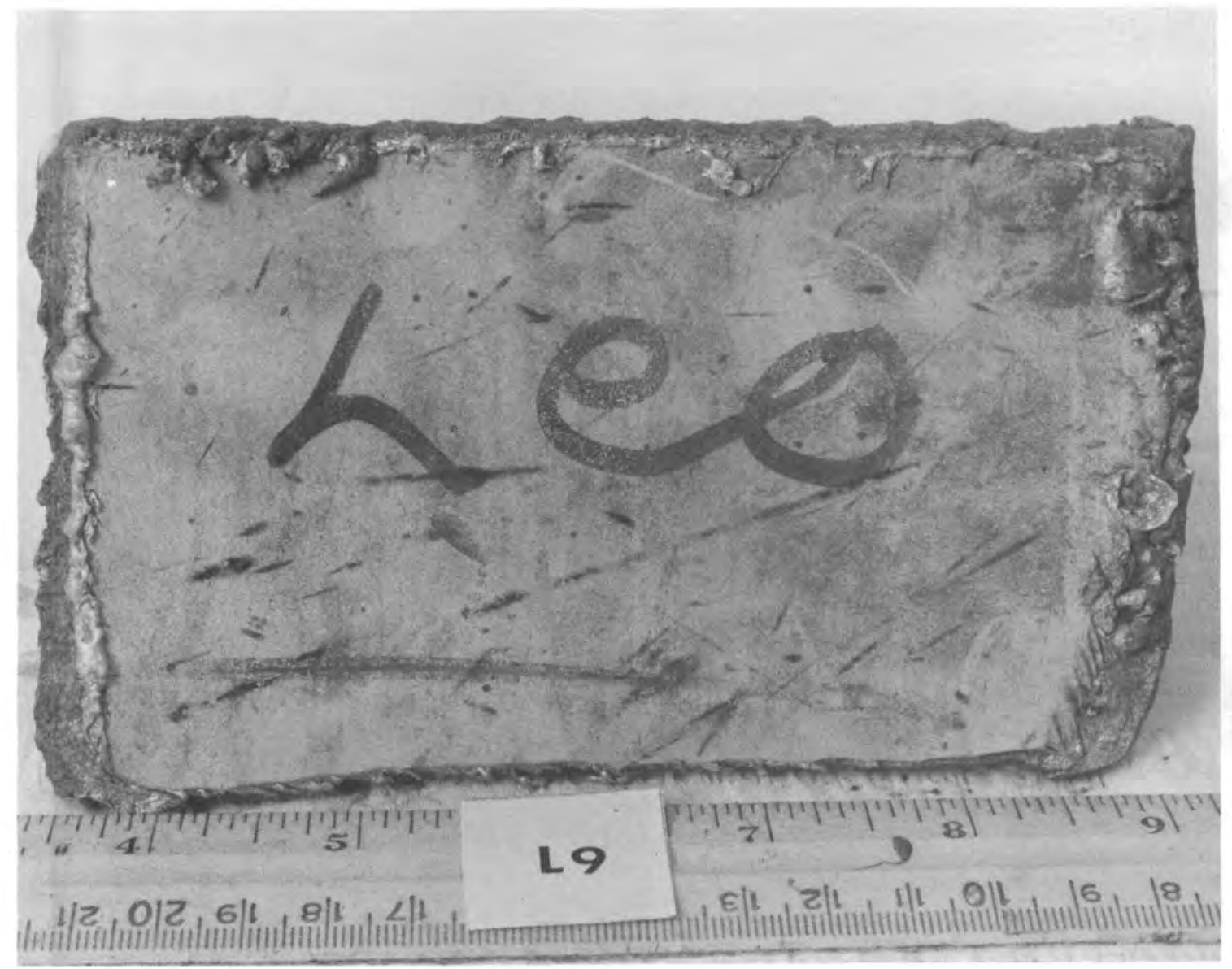

Neg. $8103218-25$

FIGURE 30. La Crosse Boral Plate Cross Section - Specimen L9. Exposed to deionized water for $3.5 \mathrm{yr}$ at 13 to $27^{\circ} \mathrm{C}$. 

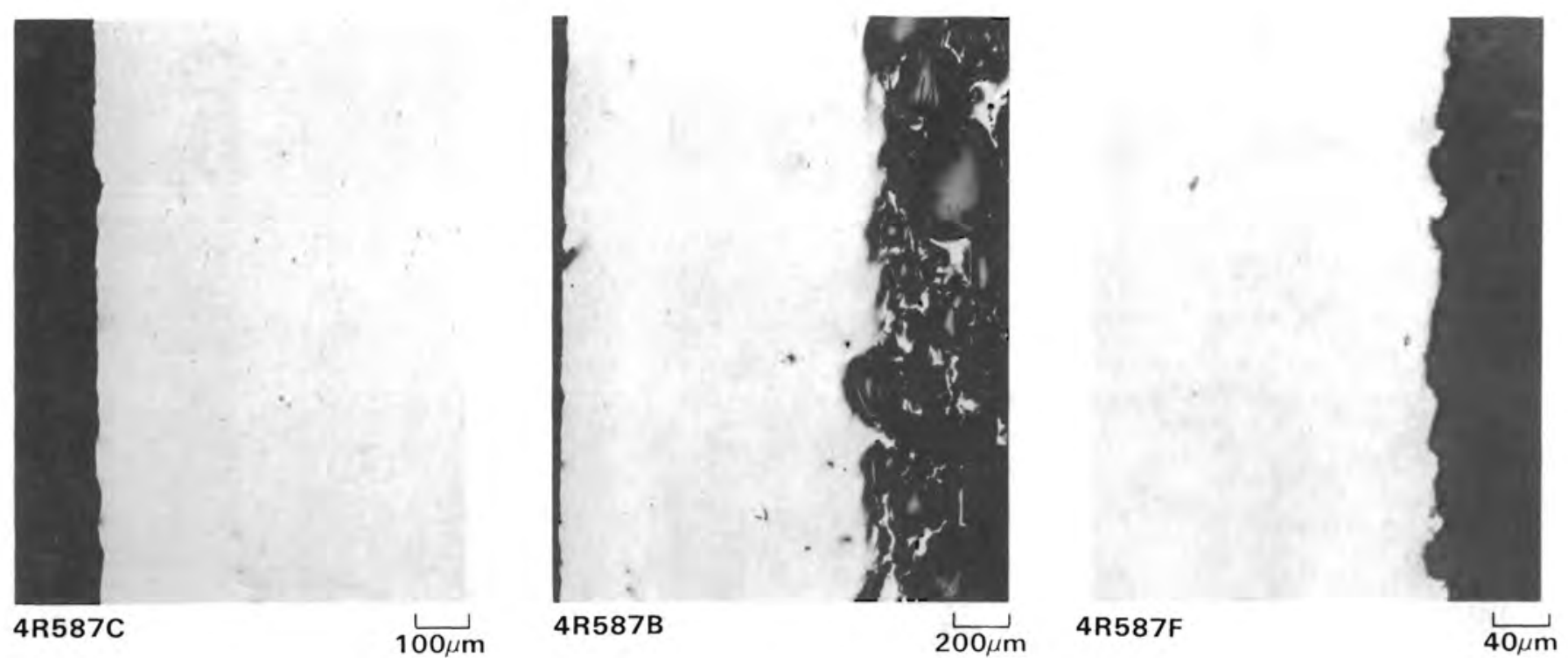

8
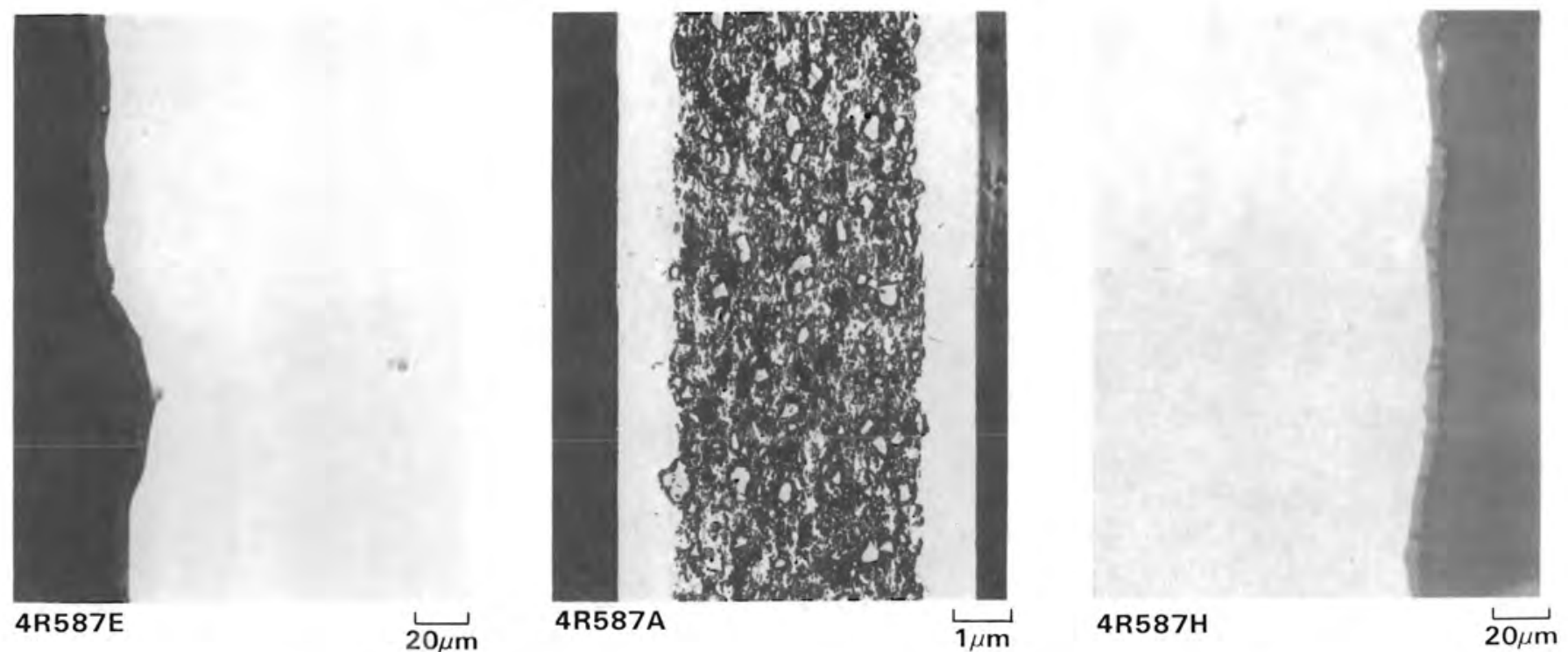

FIGURE 31. Metallographic Examination of La Crosse Boral Plate Cross Section - Specimen L9. Exposed to deionized water for $3.5 \mathrm{yr}$ at 13 to $27^{\circ} \mathrm{C} ; 35 \mathrm{wt} \% \mathrm{~B} 4 \mathrm{C}$ in an aluminum matrix clad with aluminum plates. 


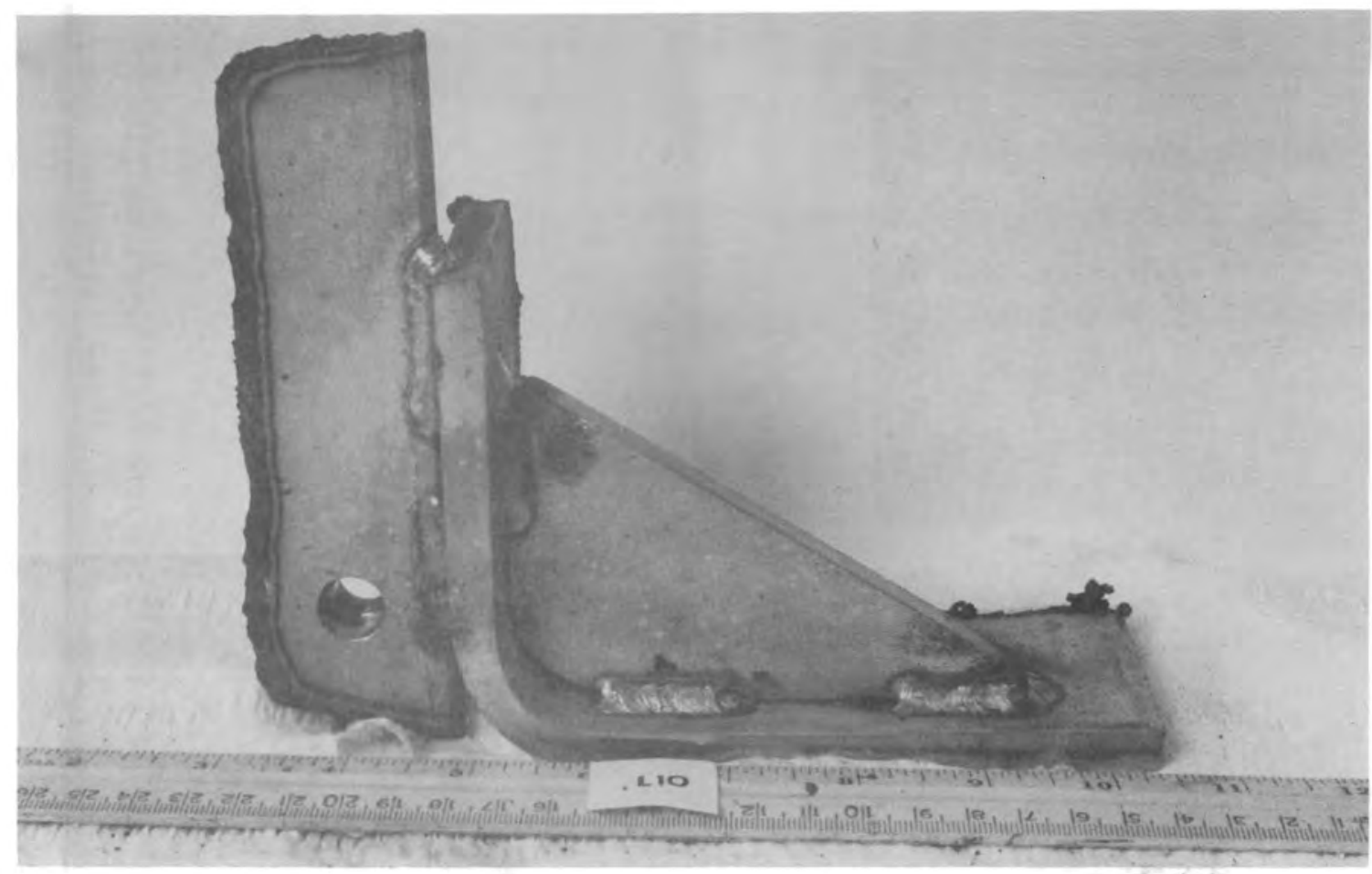

Neg. $8103218-30$

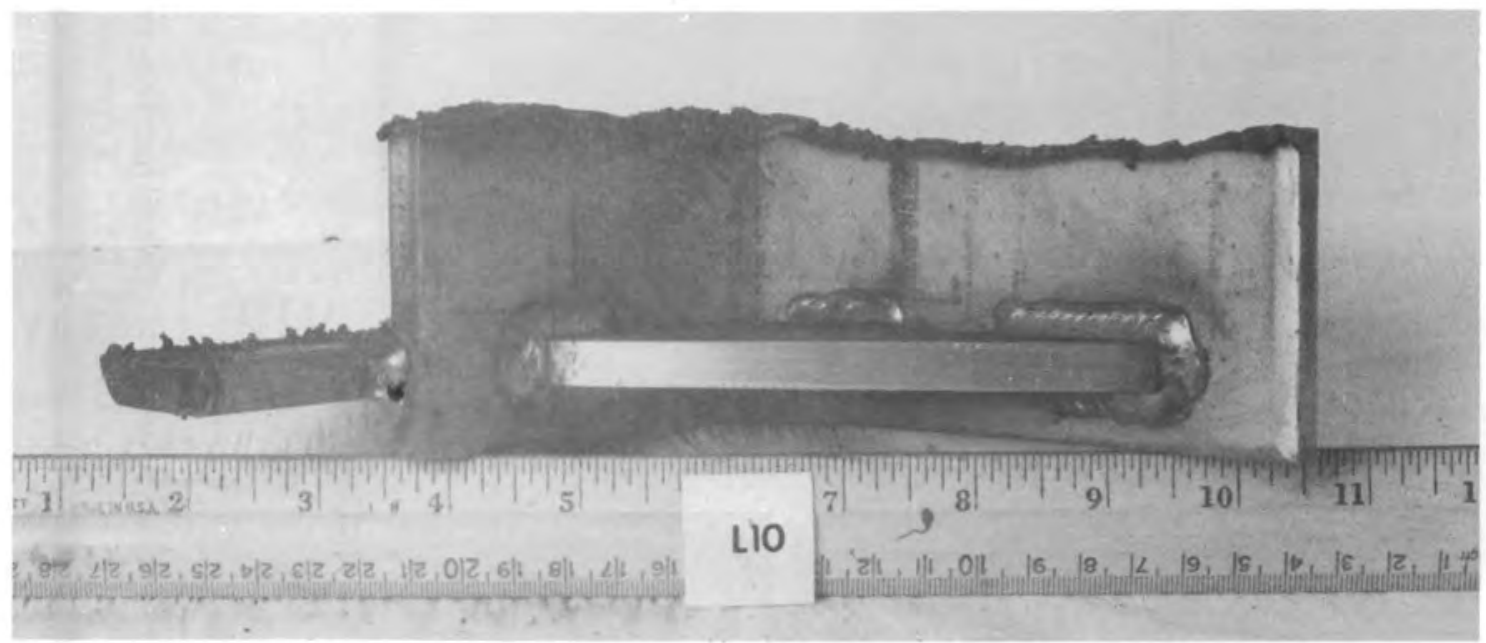

Neg. 8103218-29

FIGURE 32. Two Views of La Crosse (BWR) Fuel Storage Rack Specimen L10 (304 SS). Exposed to deionized water for $3.5 \mathrm{yr}$ at 13 to $27^{\circ} \mathrm{C}$. 


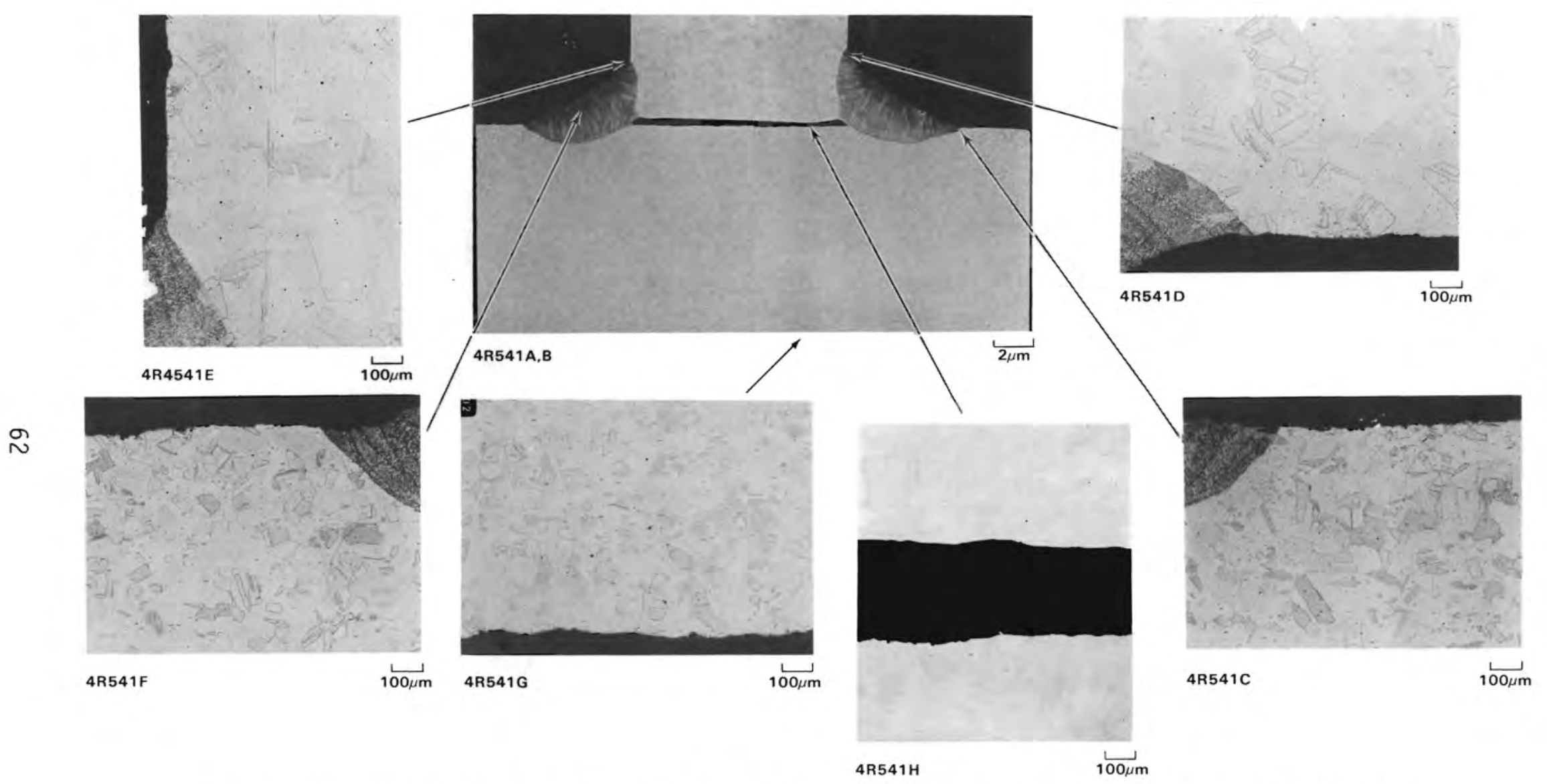

FIGURE 33. Metallographic Examination of La Crosse (BWR) Fuel Storage Rack Specimen L10 (304 SS, $0.048 \% \mathrm{C}$ ). Exposed to deionized water for $3.5 \mathrm{yr}$ at 13 to $27^{\circ} \mathrm{C}$. 


\section{EXAMINATION OF RBOF STAINLESS STEEL AND ALUMINUM COMPONENTS}

PNL received three SS specimens in April 1981 and one aluminum specimen in July 1981 from the Receiving Basin for Offsite Fuel (RBOF), Savannah River Plant, near Aiken, South Carolina. RBOF is operated for DOE by E. I. du Pont de Nemours and Company; its principal function is to store fuel from university research reactors.

The specimens included two sections of a 304 SS roller table, a section of a SS ruler that had been mounted on the table, and an aluminum spacer from a spent fuel rack. The RBOF pool chemistry and conditions are summarized below:

$$
\begin{aligned}
& \mathrm{pH}=5.5 \text { to } 7.0 \\
& \mathrm{~B}=\text { None } \\
& \mathrm{Cl}^{-}=<10 \mathrm{ppb}
\end{aligned}
$$

Temperature $=28 \pm 3^{\circ} \mathrm{C}$

Activity $=1$ to $3 \times 10^{-4}-10^{-3} \mu \mathrm{Ci} / \mathrm{ml}$

Isotopes $=90 \%{ }^{137} \mathrm{Cs}$.

The 304 SS alloy specimens were exposed to pool water for $15 \mathrm{yr}$ (1965 to September 1980). The location of the sample examined from the roller table is shown in Figure 34. The ruler was mounted on the top of the table, forming a stainless-to-stainless crevice. Figure 35 shows one of the samples as removed.

By visual examination the SS surfaces were clean and untarnished except for areas within and adjacent to the weld that were oxidized during welding. The outer surfaces were bright where the weld had been ground flush with the base metal. The inner surfaces of the weld show no spatter or evidence of excessive welding conditions. There were a number of $<0.5 \mathrm{~mm}$ diameter light brown spots on one weld and in the markings on the ruler. No other evidence of corrosion or degradation was observed. All welds appeared structurally sound. A total of 14 welds on the RBOF table specimens were visually examined, and 2 welds were metallographically investigated.

The aluminum rack spacer $(13.5 \times 8.3 \times 0.635 \mathrm{~cm})$ was manufactured from 6061-T6 aluminum alloy and exposed to pool water for $16 \mathrm{yr}$ (March 1965 to 


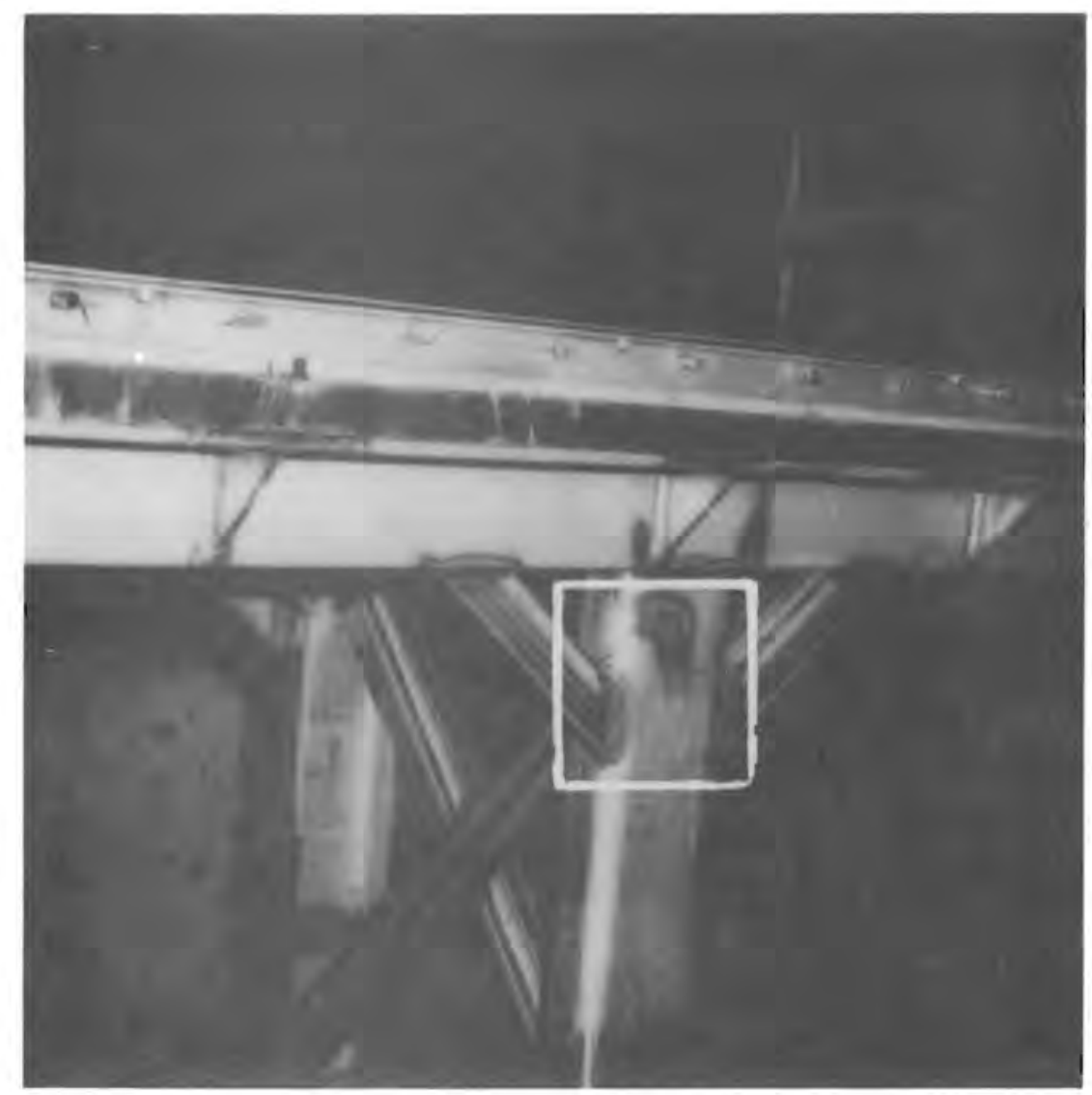

Neg. 81F573-4

FIGURE 34. Roller Table Section (304 SS) from Receiving Basin for Offsite Fuels (RBOF), Savannah River Plant. Exposed to deionized water for 15 yr at $28+3^{\circ} \mathrm{C}$; box shows section examined.

April 1981). The spacer was in contact with irradiated Zircaloy-clad fuel from the Heavy Water Components Test Reactor (HWCTR) at the Savannah River Plant, Aiken, South Carolina. The rack spacer is shown in Figure 36 as it was received at PNL. The aluminum spacer had a du11, tarnished appearance. The more heavily tar- nished areas run vertically and may have developed at points of contact with the fuel cladding. An unidentified gray paint-like deposit covered $<5 \%$ of the spacer surface. No evidence of gross corrosion or degradation was observed in visual examinations. 


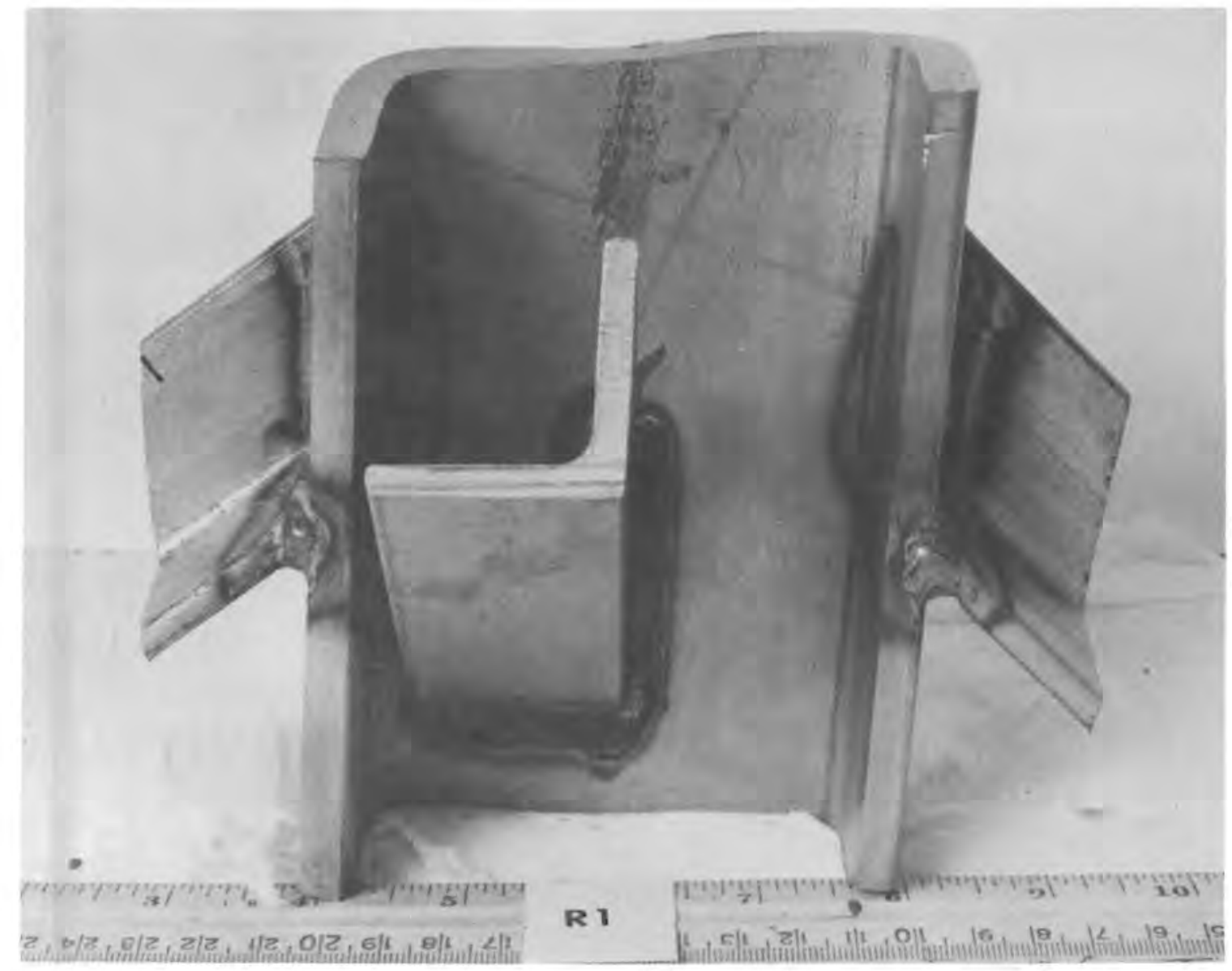

Neg. 8103218-33

FIGURE 35. RBOF Fuel Storage Roller Table Specimen RIC (304 SS). Exposed to deionized water for 15 yr at $28+3^{\circ} \mathrm{C}$.

\section{RBOF METALLOGRAPHIC ANALYSIS}

Two SS welds and a cross section of the SS ruler were examined metallographically (see Figures 37 and 38, respectively). No abnormal or atypical welds were found. In Figure 37 grain boundary widening was observed in the worked inner side of the bend, possibly due to very mild corrosion or to the manufacturing process. If due to corrosion, the widening is <75 $\mu \mathrm{m}$ in $15 \mathrm{yr}$, which would be considered minor. There was no other significant evidence of intergranular attack or other degradation.

The aluminum specimen was sectioned as shown in Figure 36 to include the following features: the crevice region between the spacer and the other 


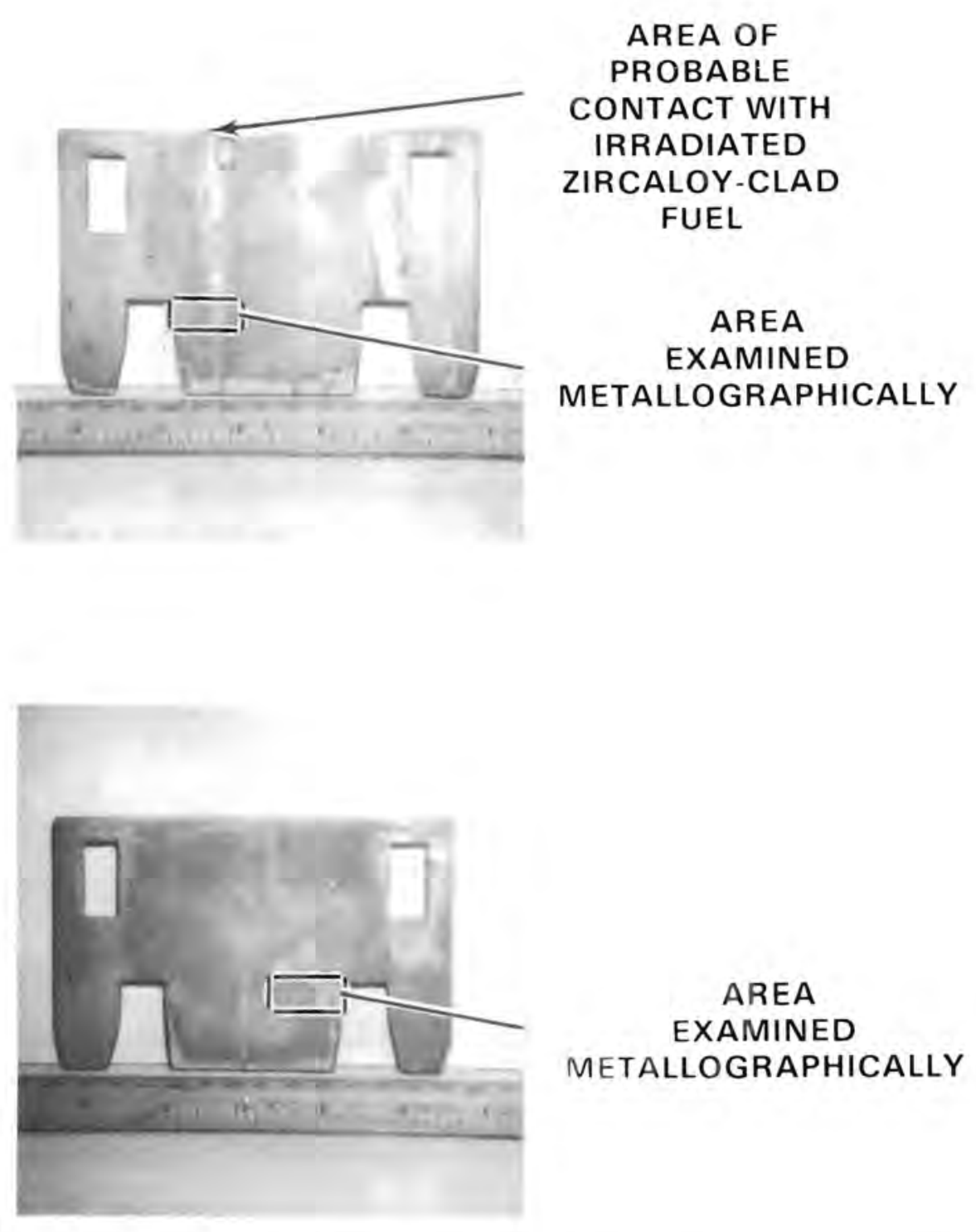

FIGURE 36. Front and Back Views of RBOF Aluminum Fuel Rack Spacer. Exposed to deionized water for 16 yr at $28 \pm 3^{\circ} \mathrm{C}$.

aluminum plates in the fuel rack, the tarnished region at the possible Zircaloy cladding contact, and an area that was open to the pool water. Figure 39 shows the oxide layer at various points on the sample; at some points the oxide layer was pulled away from the base metal by the mounting material. The oxide layer varied from 8 to $20 \mu \mathrm{m}$. The thickest oxide was found near the middle of the sample and in the tarnished region; the layer was thinnest in the crevice region. 


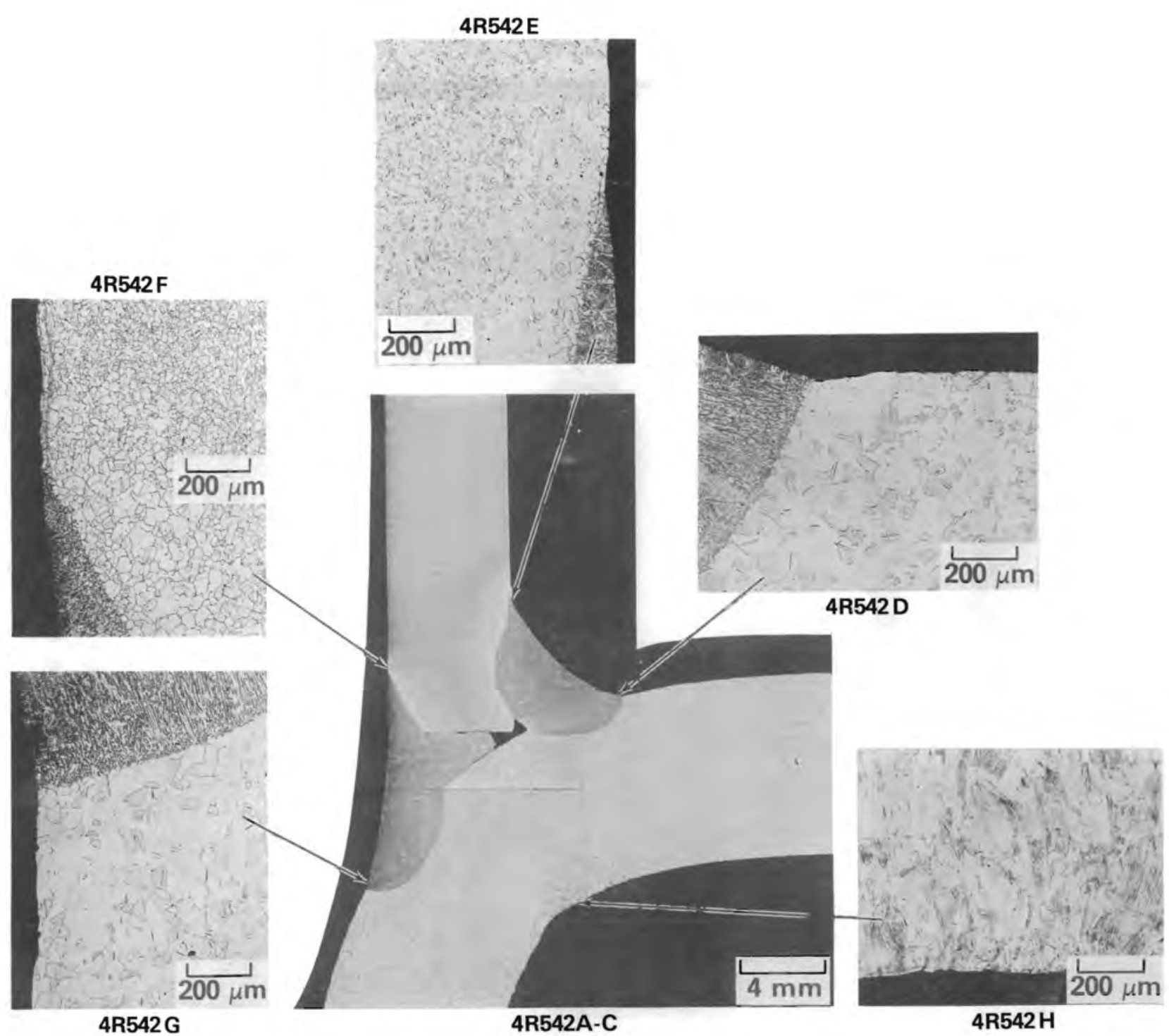

FIGURE 37. Metallographic Examination of RBOF Fuel Storage Roller Table Specimen RIC (304 SS). Exposed to deionized water for 15 yr at $28+3^{\circ} \mathrm{C}$. 

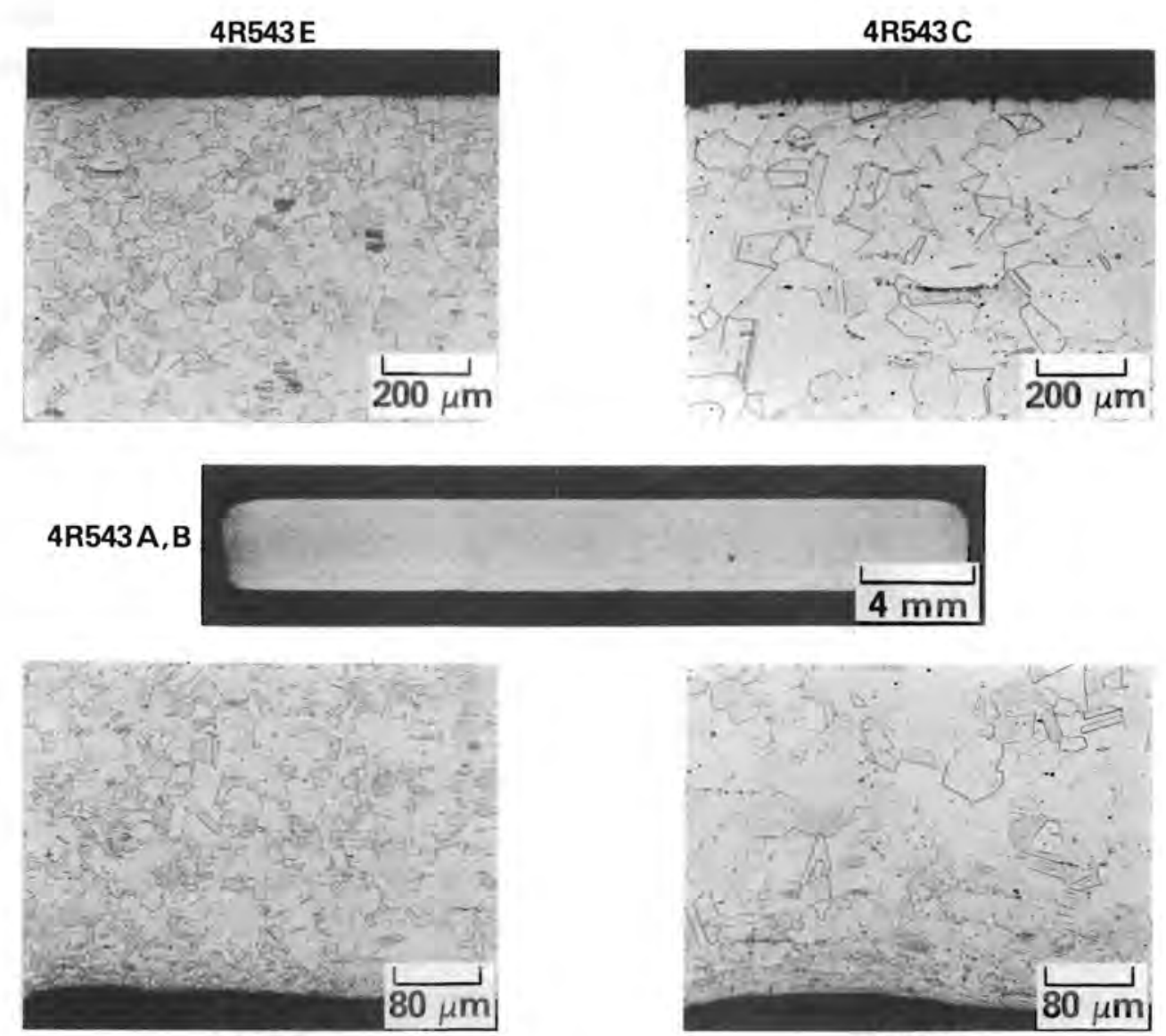

4R543F

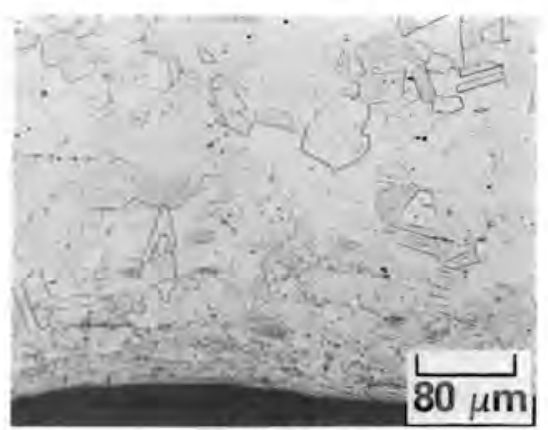

4R543D

FIGURE 38. Metallographic Examination of RBOF Fuel Storage Roller Table Ruler Specimen R3B (304 SS). Exposed to deionized water for 15 yr at $28+3^{\circ} \mathrm{C}$.

Figure 40 shows the aluminum specimen after a $0.5 \%$ HF etch. The elongated grain structure indicates that the aluminum was rolled or extruded. Figure $40 \mathrm{~B}$ shows some evidence of local mechanical damage. Some mild pitting occurred in the crevice, tarnished, and open regions. The pitting depth was less than $20 \mu \mathrm{m}$ and showed no preference for grain boundary attack. No significant difference in pitting or other corrosion was observed in the crevice or tarnished regions compared to the open regions of the sample. No other degradation or corrosion was observed on the aluminum spacer. 

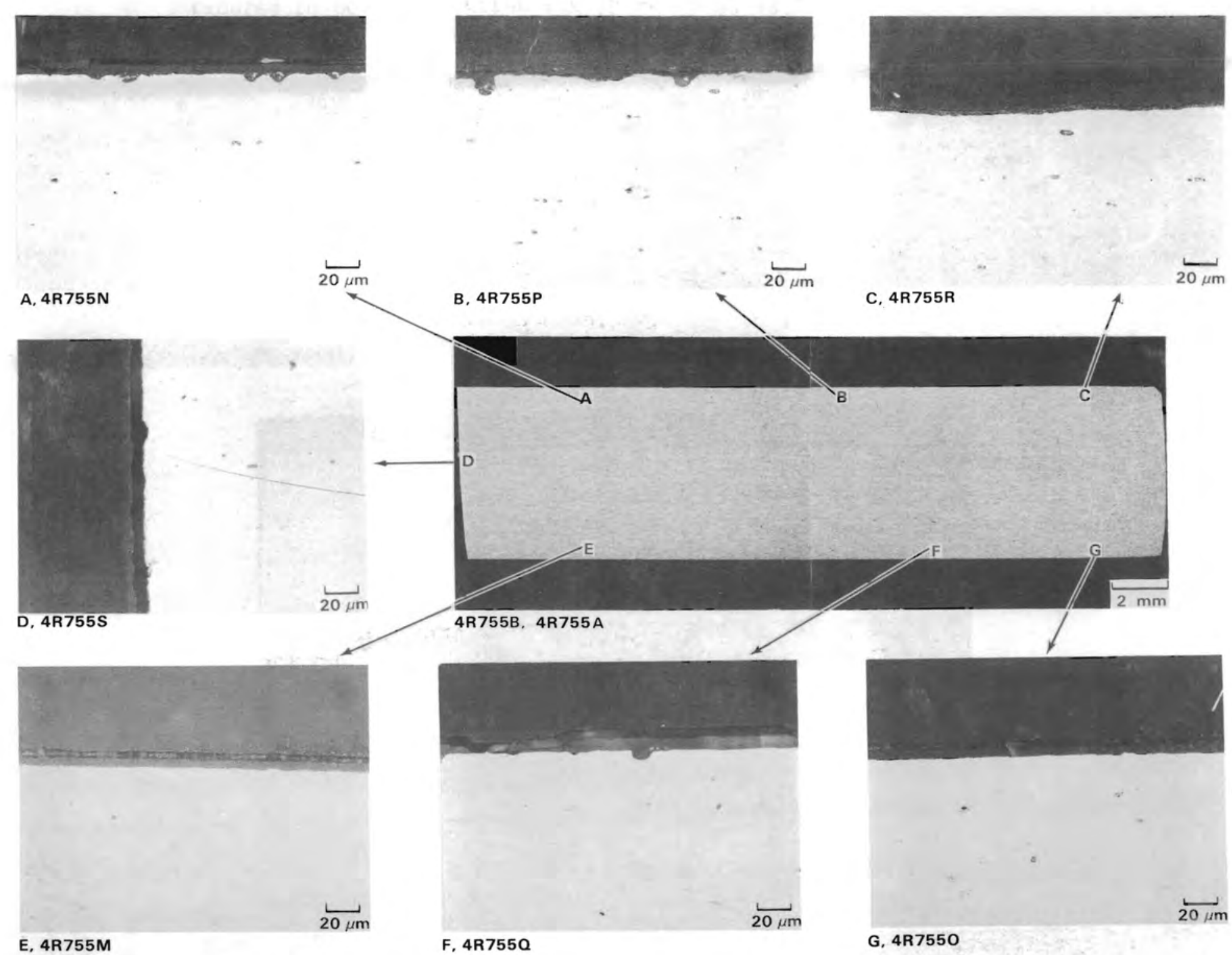

FIGURE 39. Oxide Layers on RBOF Aluminum Fuel Rack Spacer. Exposed to deionized water for 16 yr at $28 \pm 3^{\circ} \mathrm{C}$. 


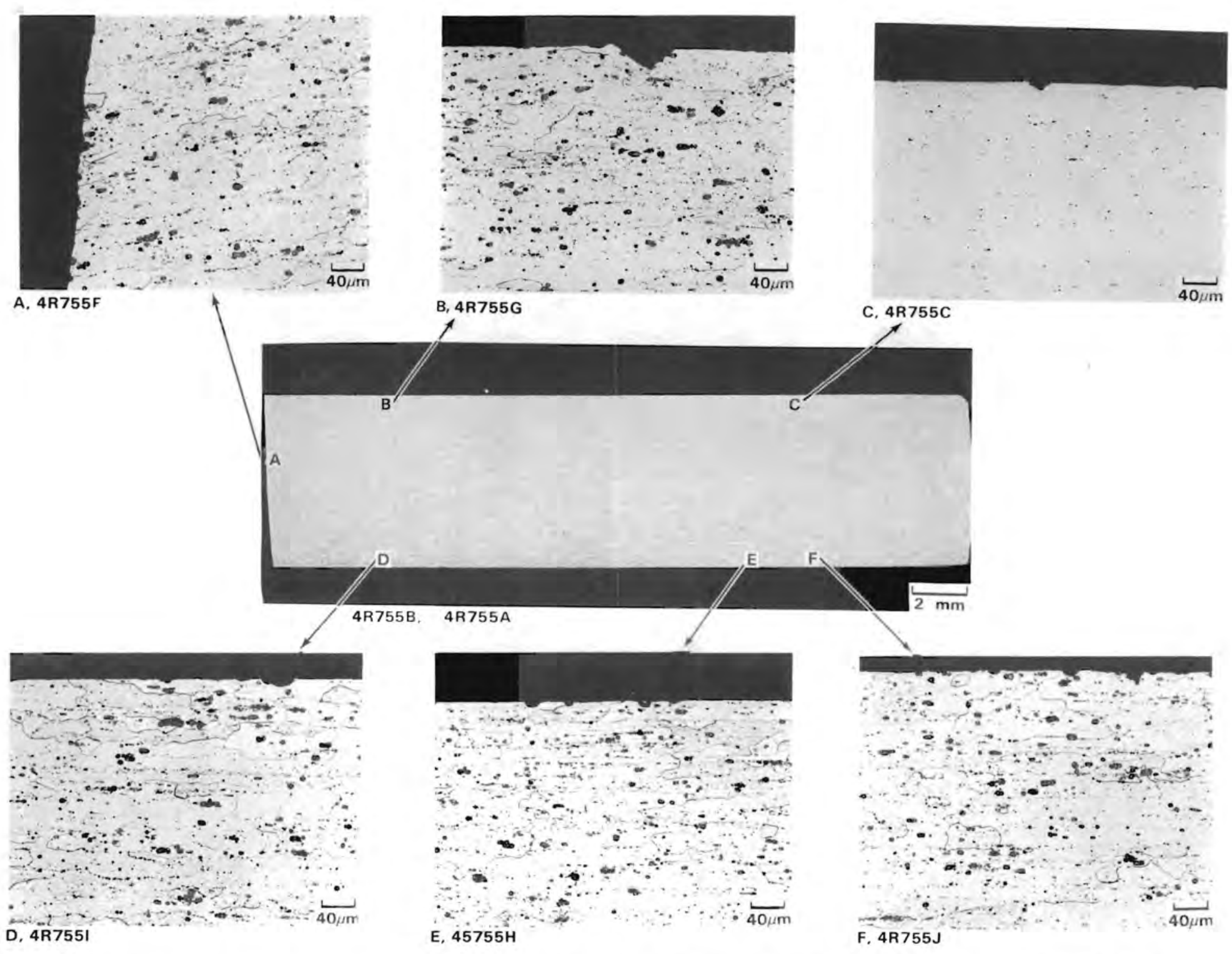

FIGURE 40. Metallographic Examination of RBOF Aluminum Fuel Rack Spacer Alloy 6061-T6. Exposed to deionized water for 16 yr at $28 \pm 3^{\circ} \mathrm{C}$. 
After $15 \mathrm{yr}$ of exposure to RBOF deionized pool water, the 14 alloy 304 SS welds and the SS ruler-crevice section showed no evidence of significant intergranular attack or other corrosion. After $16 \mathrm{yr}$ of exposure in the RBOF pool in close proximity and probable contact with Zircaloy-clad spent fuel, the aluminum spacer had developed an 8- to 20-um oxide layer and some minor pitting $(<20 \mu \mathrm{m})$.

The integrity of the stainless steel and the aluminum specimens was not significantly changed by corrosion after 15 to $16 \mathrm{yr}$ of pool residence. 


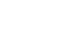


During the period from November 1974 to February 1977 several reactors with boric acid systems developed SCC in pipes at locations near welds. (a) In response to the appearance of these cracks the NRC issued Circular 76-06. (24) The circular indicated that:

- cracks were adjacent to weld zones in thin-walled low-pressure pipes, which were not part of the reactor coolant system

- cracking occurred in normally stagnant pipe segments

- analysis of surface products indicated that chloride ions are a probable factor, together with a stress state in the pipe due to welding and/or fabrication.

During the refueling outage of TMI-Unit 1 in February 1979, six (b) through-wall cracks were observed near welds in the SFP cooling system piping and one at a weld in the decay heat removal system. The cracks were detected due to local crusts of boric acid that developed when the solution seeped through the cracks and the small amount of water evaporated. Radiation levels on the crusts were low due to low concentrations of radioactivity in the pool water.

The TMI-Unit 1 SFP system has two cooling loops: loop A, which is redundant and therefore normally stagnant; and loop $B$, which is normally circulating. All but one of the pipe cracks developed in the stagnant loop A piping, and all cracks occurred in weld heat-affected zones in pipe sections with carbon levels exceeding $0.07 \mathrm{wt} \%$.

An extensive nondestructive testing (NDT) program was instituted at TMIUnit 1, and ultrasonic testing identified several hundred "indications." Subsequent calibrations and metallographic correlation suggested that only 39 of

(a) For example, see entries in Appendix A for Arkansas Nuclear No. 1, 9-26-76, 12-1-76, 5-5-77, 11-25-77; Millstone, 4-22-76; San Onofre, 1-17-77; Trojan, 10-10-77; 3-8-78. Cracks have also developed in boric acid system piping at three Japanese PWRs.

(b) A seventh crack was later discovered. (4) 
the indications represented partial through-wall cracks. Discovery of the TMIUmit 1 pipe cracks prompted NRC to issue IE Bulletin No. 79-17. (25)

The Electric Power Research Institute (EPRI), Palo Alto, California, commissioned studies to provide insight into the nature of the cracking phenomenon; they can be summarized as follows:

- There has been no evidence that 304 and 304L SS will crack in uncontaminated oxygen-saturated boric acid environments characteristic of PWR pools.

- Stainless steel in boric acid environments with 15-ppn $\mathrm{Cl}^{-}$added has cracked in one test but not in another. The incidence of cracking may be related to the degree of sensitization, although this has not been conf irmed.

The cracking phenomenon is not currently regarded as a safety problem. However, costs associated with replacing cracked piping have prompted EPRI to investigate a program to conduct mechanism studies and identify countermeasures.

The Spent Fuel and Fuel Pool Component Integrity Program at PNL has conducted a study of the pipe cracking phenomenon to provide a perspective relevant to spent fuel component integrity. A section of TMI-Unit 1 pipe (Figure 41) with a through-wall crack was subjected to metallographic and analytical examination, and sections of the pipe have undergone SCC tests in various media. Results of the examination were presented at the Corrosion 81 Conference in Toronto. $(26,27)$ Intergranular SCCS (IGSCCS) found in the weld heataffected zone of the pipe have been evaluated by a series of analytical tests. The intergranular nature of the cracks was identified by optical metallography and scanning electron microscopy (SEM). The presence of $\mathrm{Cl}^{-}$was observed by energy dispersive $x-r a y$ analys is (EDAX) and Auger electron spectroscopy (AES). Sulfur was observed by EDAX and AES both as particles and uniformly on the fracture surface.

Constant extension rate tests (CERT) performed on specimens removed from the pipe and containing the weld heat-affected zones demonstrated that 15-ppm $\mathrm{Cl}^{-}$in a $1.3 \mathrm{wt} \% \mathrm{H}_{3} \mathrm{BO}_{3}$ solution was sufficient to cause IGSCC when the 


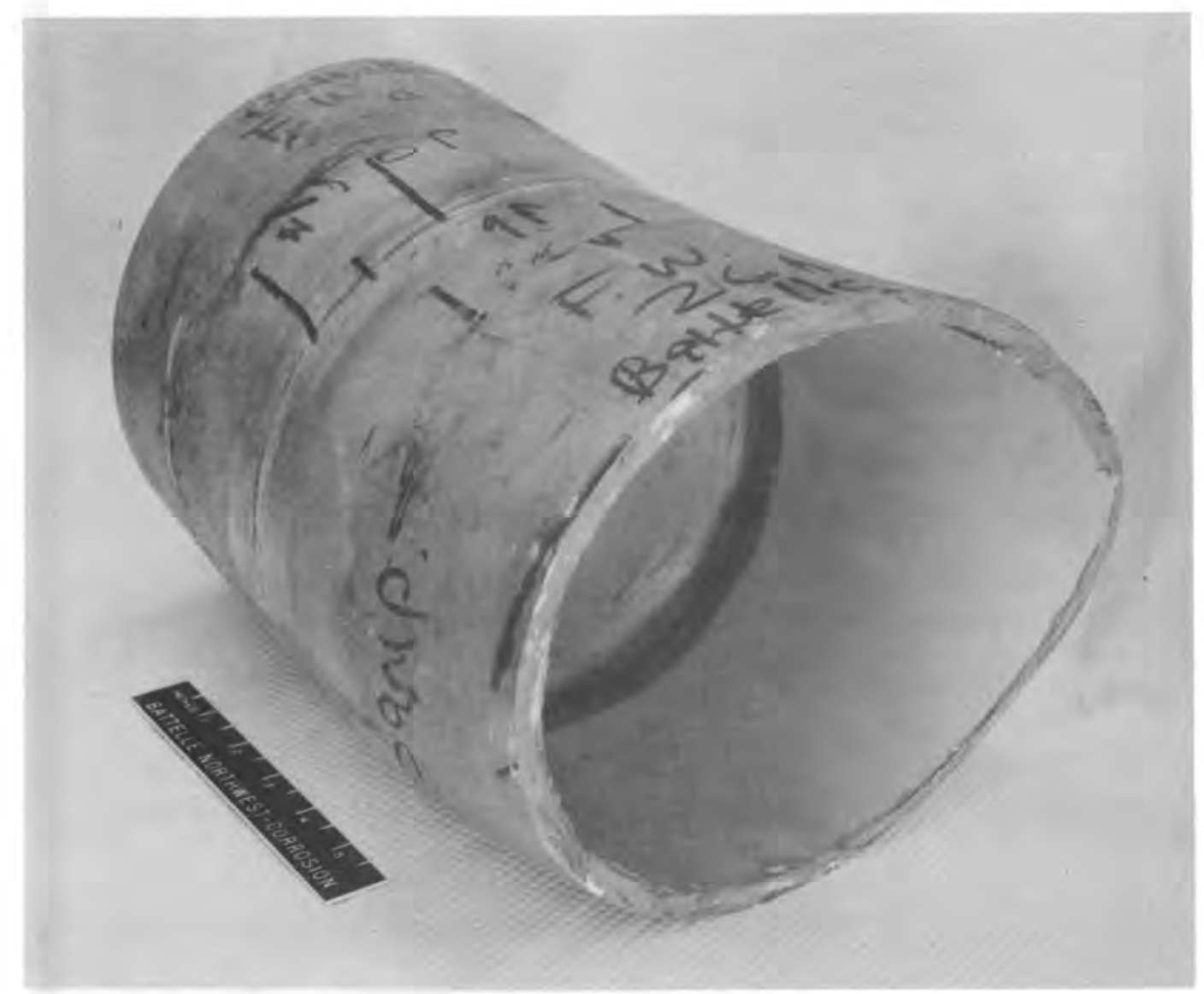

Neg. 79E241-2

FIGURE 41. Section of Three Mile Island-Unit 1304 SS Pipe from a Stagnant Leg of the Spent Fuel Pool Heat Transport System

original pipe surface was present. Removal of this surface resulted in $100 \%$ ductile (microvoid coalescence type) fracture for the same test condition. The association of cracks with grinding marks and surface defects in the asreceived pipe also supports the conclusion that surface defects contributed to crack initiation.

To date there is no indication that similar cracks have occurred in SS components in SFPs with deionized water chemistry. However, both deionized water and boric acid chemistries are included in the studies underway at PNL. 
-

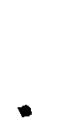




\section{REFERENCES}

1. Johnson, A. B., Jr. September 1977. Behavior of Spent Nuclear Fuel in Water Pool Storage. BNWL-2256, Pacific Northwest Laboratory, Richland, Washington.

2. Johnson, A. B., Jr., et al. May 1980. Annual Report - FY-1979 Spent Fuel and Fuel Pool Component Integrity. PNL-3171, Pacific Northwest Laboratory, Richland, Washington.

3. Czajkowski, C., J.R. Weeks, and S. R. Prolter. 1981. "Corrosion of Structural and Poison Material in Spent Fuel Storage Pools." Paper presented at Corrosion 81, April 6-10, 1981, Toronto, Canada.

4. Giacobbe, F. S. 1981. "Examination, Evaluation, and Repairs of Stress Corrosion Cracking in a PWR Borated Water Piping System." Presented at Corrosion 81, April 6-10, 1981, Toronto Canada.

5. Vincent, D. M., and D. E. Nevinski. 1981. "Monticello Spent Fuel Storage Module Corrosion Experience." Paper presented at Corrosion 81, April 6-10, 1981, Toronto, Canada.

6. Zimmerman, C. A. 1981. "Control of Corrosion in an Aqueous Nuclear Fuel Storage Basin." Paper presented at Corrosion 81, April 6-10, 1981, Toronto, Canada.

7. Phillips, A. L., ed. 1969. Welding Handbook. 6th ed. Section 2 Welding Processes: Gas, Arc, and Resistance. American Welding Society, New York.

8. Weisman, C., ed. 1976. Welding Handbook. 7th ed. Vol. 1 - Fundamentals of Welding. American Welding Society, New York, pp. 80-98.

9. Jhaveri, P., W. G. Moffatt, and C. M. Adams, Jr. January 1962. "The Effect of Plate Thickness and Radiation on Heat Flow in Welding and Cutting." Welding Research Supplement, p. 125-165.

10. Adams, C. M., Jr. May 1958. "Cooling Rates and Peak Temperatures in Fusion Welding." Welding Research Supplement, p. 2105-2155.

11. Povich, M. J., and R. E. Smith. 1979. "An Overview of Intergranular Stress Corrosion Cracking in Light Water Reactors." In Corrosion/79, Paper 235, March 12-16, 1979, Atlanta, Georgia.

12. Welch, G. A., et al. 1979. "Stress Corrosion Cracking of Sensitized Type 304 Stainless Steel in High Purity Water." In Corrosion/79, Paper 48, March 12-16, 1979, At lanta, Georgia. 
13. Ford, F. P., and M. J. Povich. 1979. "The Effect of Oxygen/Temperature Combinations on the Stress-Corrosion Suscoptiblity of Sensitized 304 Stainless Steel in High Purity Water." In Corrosion/79, Paper 94, March 12-16, 1979, At lanta, Georgia.

14. Armiji, J. S. July 1965. "Intergranular Corrosion of Nonsensitized Austentic Stainless Steels - I. Environmental Variables." CorrosionNACE 21:235-244.

15. Armiji, J. S. January 1968. "Intergranular Corrosion of Nonsensitized Austenitic Stainless Steels." Corrosion-NACE 24:24-30.

16. Joshu, A., and D. F. Stein. September 1972. "Chemistry of Grain Boundaries and Its Relation to Intergranular Corrosion of Austenitic Stainiess Stee1." Corrosion-NACE 28(9):321-329.

17. Scharfstein, L. R., and W. F. Brindley. 1958. "Chloride Stress Corrosion Cracking of Austenitic Stainless Steel - Effect of Temperature and $\mathrm{pH} . "$ Corrosion-NACE 1:588t-592t.

18. Edklund, G. S. April 1979. "Initiation of Pitting at Sulfide Inclusions in Stainless Steel." J. Electrochem. Soc. 121(4):467-473.

19. Ward, C. T., D. L. Mathis, and R. W. Staehle. September 1969. "Intergranular Attack of Sensitized Austenitic Stainless Steel by Water Containing FLuoride Ions." Corrosion-NACE 25(9):294-6.

20. Theus, 0. J., and R. Ce11. 1974. "Fluoride Induced Intergranular Stress Corrosion Cracking of Sensitized Stainless Steels." In Corrosion Problems in Energy Conversion and Generation, The Electrochemical Society, ed. C. S. Tedmor, Princeton, New Jersey, p. 389-396.

21. Giannuzzi, A. J. 1976. "Intergranular Stress Corrosion Cracking of Austenitic Stainless Steels." Report NED0-21000, General Electric, San Jose, California.

22. Giannuzzi, A. J. December 1978. "Studies on AISI Type 304 Stainless Steel Piping Weldments for Use in BWR Application." EPRI NP-944, Electric Power Research Institute, Palo Alto, California.

23. Hamner, N. E. March 1974. Corrosion Data Survey. 5th ed. National Association of Corrosion Engineers, Houston, Texas.

24. U.S. Nuclear Regulatory Commission. 1976. Stress Corrosion Cracks in Stagnant, Low Pressure Stainless Piping Containing Boric Acid Solutions at PWRs. IE Circular No. 76-06, November 26, 1976, Washington, D.C. 
25. U.S. Nuclear Regulatory Commission. 1979. Pipe Cracks in Stagnant Borated Water Systems at PWR Plants. IE Bulletin No. 79-17, July 26, 1979, Washington, D.C.

26. Jones, R. H., A. B. Johnson, Jr., and F. S. Giacobbe. 1981. "Assessment of Stress Corrosion Cracking in a Spent Fuel Pool Pipe." Paper presented at Corrosion 81, Apri1 6-10, 1981, Toronto, Canada. 

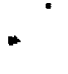

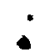


APPENDIX A

INCIDENT REPORTS 


\section{APPENDIX A}

\section{INCIDENT REPORTS}

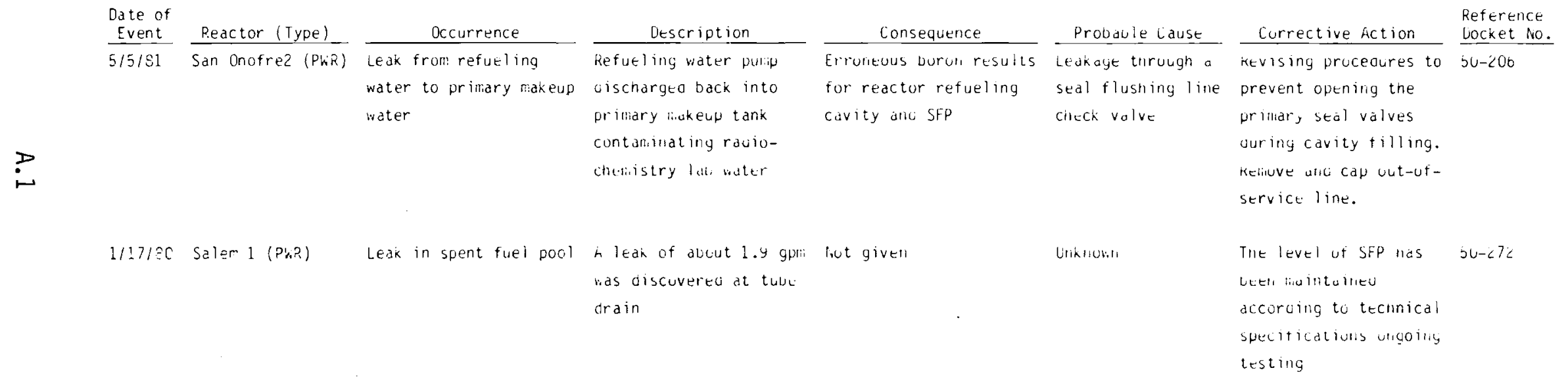


SUMMARY OF EVENTS INVOLVING SFP EQUIPMENT

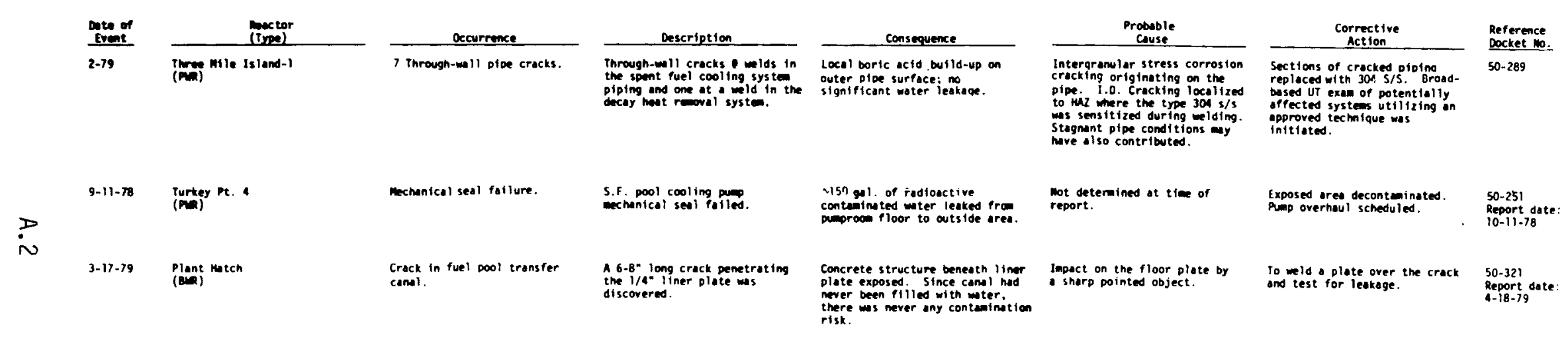




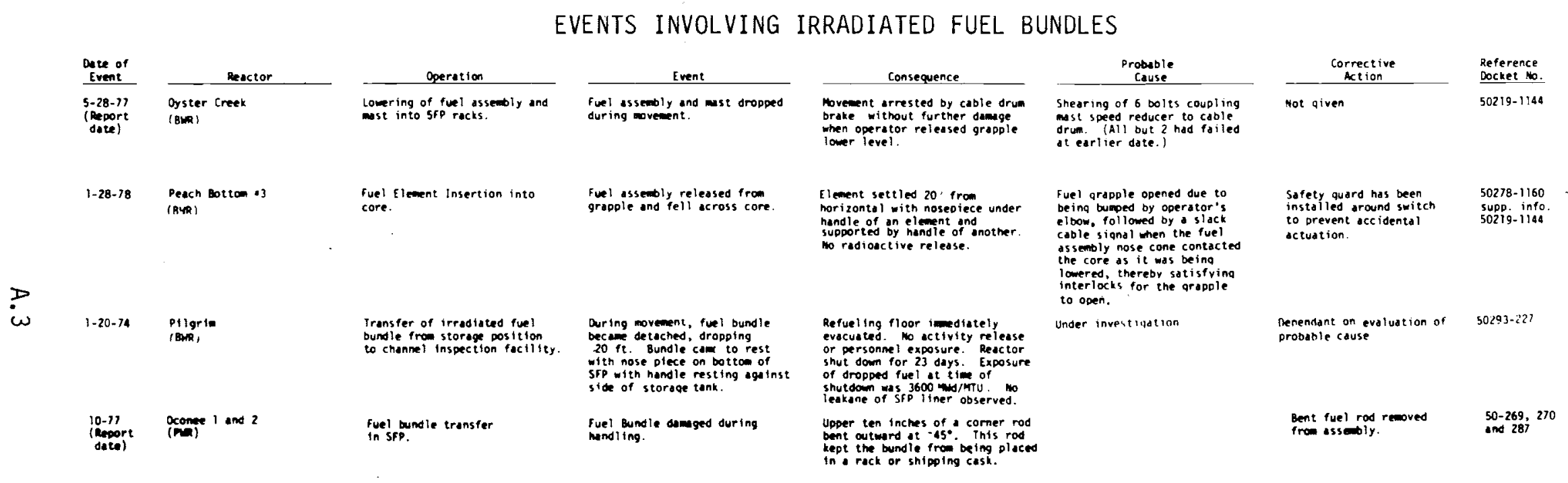

a) See table of meferences for soditional fuel handing events in the same tive period. 


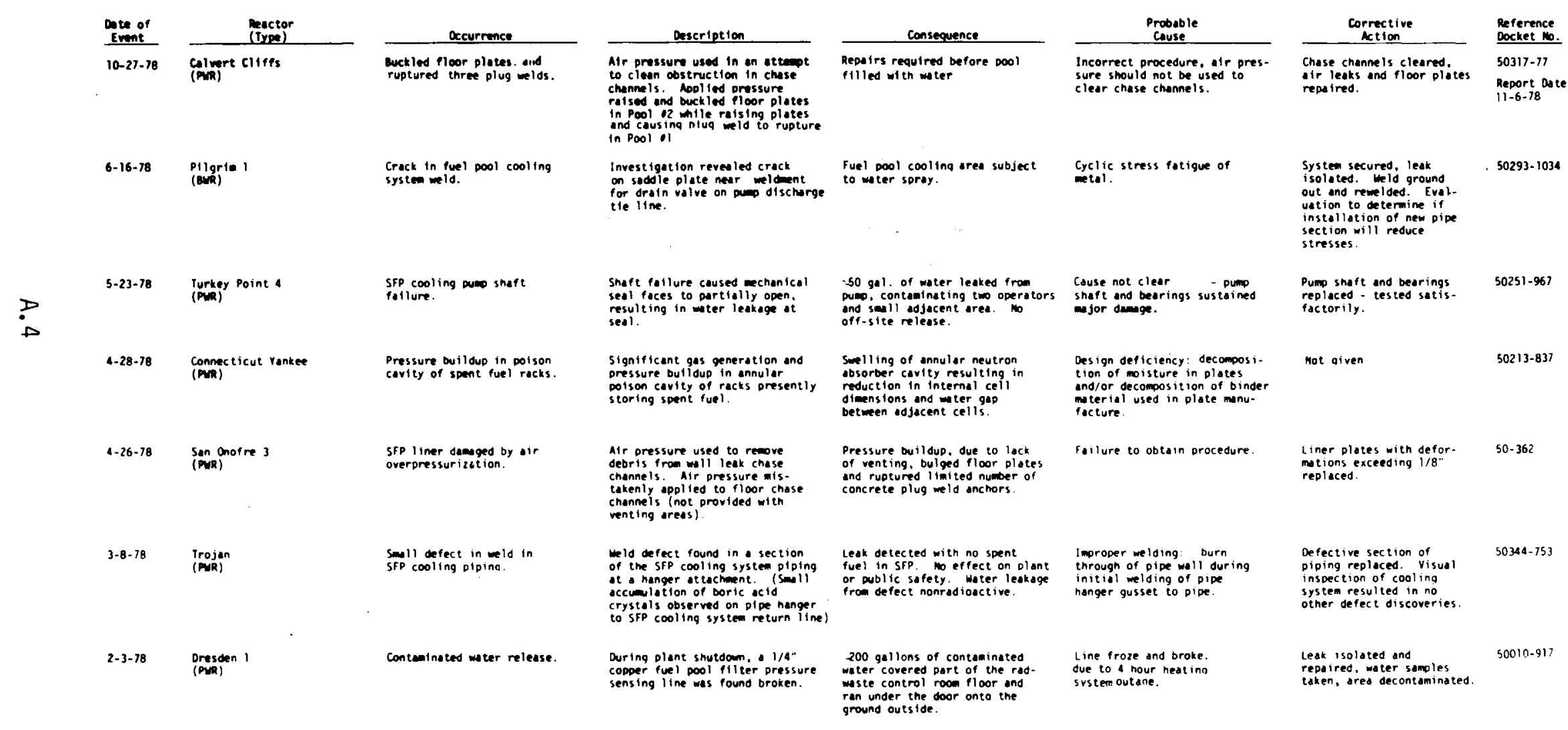




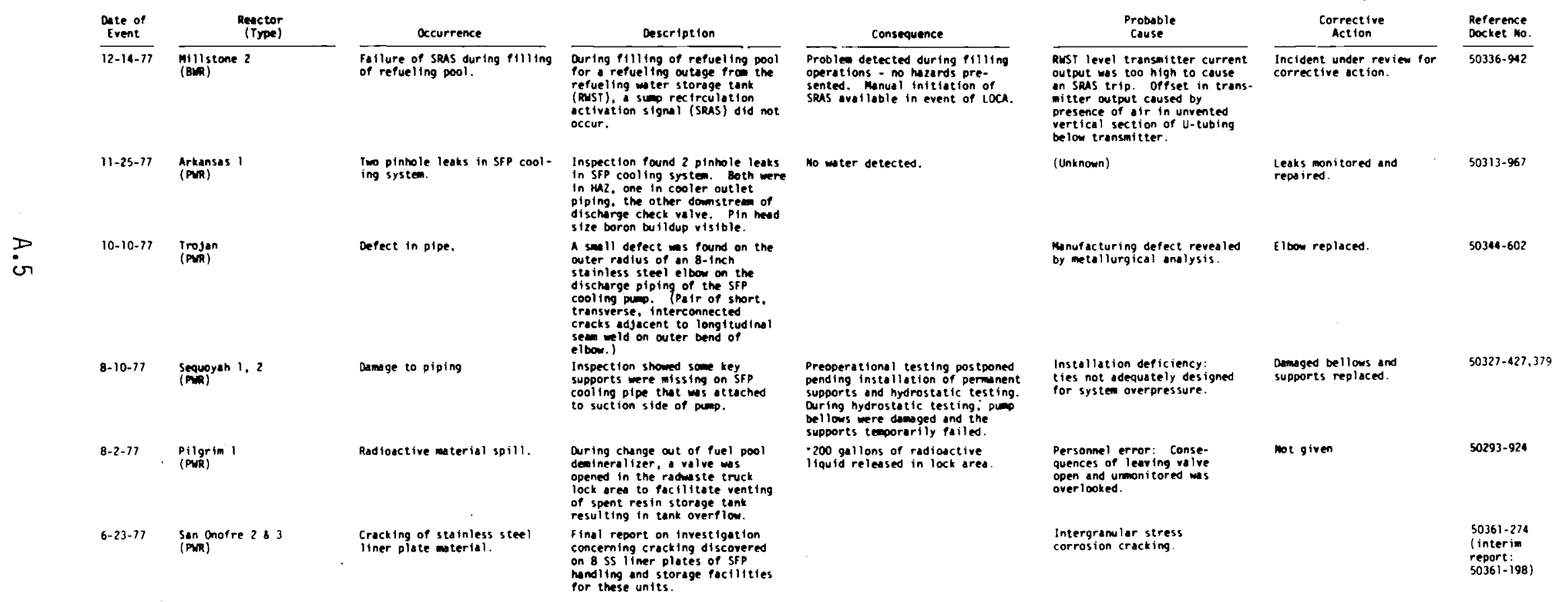




\begin{tabular}{|c|c|c|c|c|c|c|c|}
\hline Dace of & Foctor & excurrence & _Description & Consequence & $\begin{array}{c}\text { Probosble } \\
\text { Ceause }\end{array}$ & $\begin{array}{c}\text { Corrective } \\
\text { Action } \\
\end{array}$ & $\begin{array}{l}\text { Reference } \\
\text { Docket ko. }\end{array}$ \\
\hline $5-5.71$ & Netensses 1 & Leak in SFp dischurge piping. & 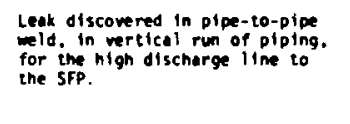 & $\begin{array}{l}\text { Concas ined leas, no hazard to } \\
\text { nead th. }\end{array}$ & (Unknom) & 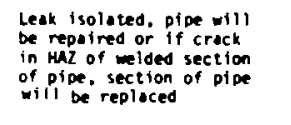 & $50313-721$ \\
\hline $4-21-n$ & 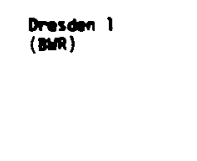 & Ruptures wat $11 \mathrm{mer}$. & $\begin{array}{l}\text { Fusl pool neat exchnanger inlet } \\
\text { vent } 11 \text { ine ruptured. }\end{array}$ & 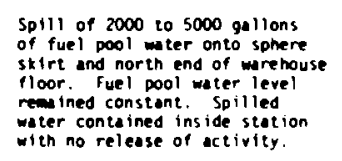 & $\begin{array}{l}\text { Corrodeded and eackened short } \\
\text { nipple on welded coupl ing } \\
\text { riiled. }\end{array}$ & 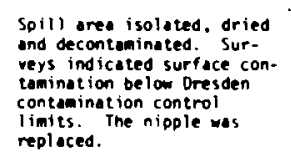 & $50010-790$ \\
\hline $2-28-71$ & 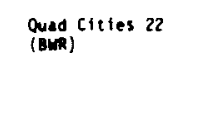 & 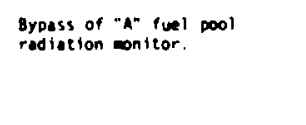 & 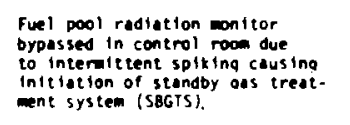 & (Mot Given) & 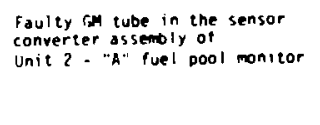 & 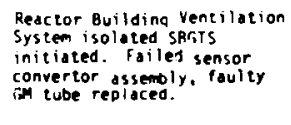 & 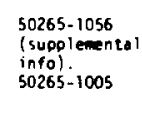 \\
\hline $1-20.11$ & $\begin{array}{l}\text { Artuensos } \\
(\text { PWR })\end{array}$ & Leak in pipe wit. & 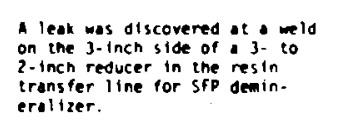 & 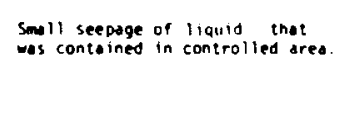 & (Unknom) & $\begin{array}{l}\text { Section of } 2 \text {-inch pipe } \\
\text { ind reducer replaced. }\end{array}$ & $50313-716$ \\
\hline 1.17 .17 & 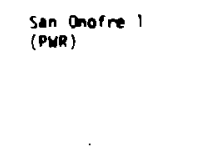 & flow in pipe. & 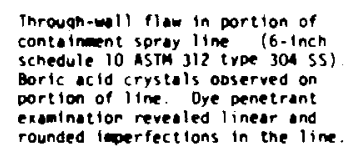 & (not Given) & 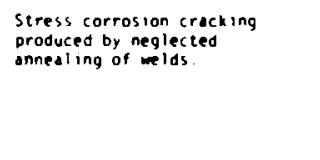 & Pipe replaced. & $50206-664$ \\
\hline $1-16-77$ & G. E. worris & remporary shutooun of & 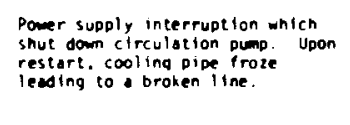 & 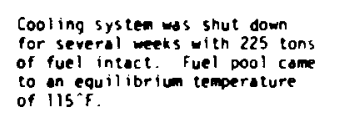 & Loss of Pouner. & System repoi ired. & 701308 \\
\hline $12-1-76$ & $\begin{array}{l}\text { Arkensus } \\
\text { (ntan) })\end{array}$ & $\begin{array}{l}\text { wocer leak from vilue in SFP } \\
\text { cooling system. }\end{array}$ & 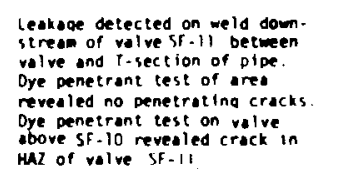 & 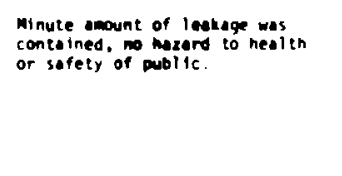 & (Unnown) & Sf-11 waive replaced. & $50313-693$ \\
\hline
\end{tabular}




\begin{tabular}{|c|c|c|c|c|c|c|c|}
\hline $\begin{array}{l}\text { Datre of } \\
\text { Event }\end{array}$ & $\begin{array}{l}\text { Reactor } \\
\text { (Type) }\end{array}$ & accurrence & Deseripeton & Consequence & $\begin{array}{c}\text { Probable } \\
\text { Couse }\end{array}$ & $\begin{array}{c}\text { Corrective } \\
\text { Nction }\end{array}$ & $\begin{array}{l}\text { Reference } \\
\text { Docket ito. }\end{array}$ \\
\hline $11-12-76$ & $\begin{array}{l}\text { Brunswick } 2 \\
\text { (BWR) }\end{array}$ & $\begin{array}{l}\text { SFP water level inadvertently } \\
\text { laered. }\end{array}$ & 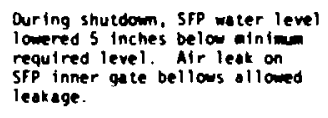 & $\begin{array}{l}\text { Leakege of woter through bellous } \\
\text { entered dratin. Ores in rolve shut } \\
\text { and bellows repressurized. }\end{array}$ & Leak on pool gate bellows. & bellows repaired. & $50324-968$ \\
\hline $11-3-76$ & $\begin{array}{l}\text { Peach Bottom } 1 \\
\text { (HTGR) }\end{array}$ & Tube leak. & 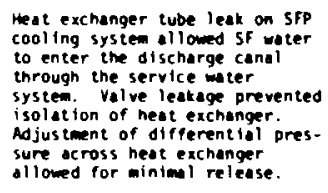 & 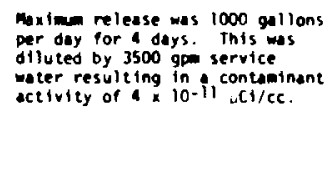 & (Unknom) & 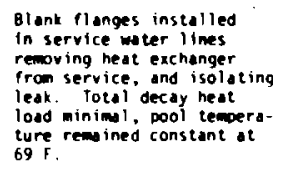 & $50171-215$ \\
\hline $9-26-76$ & $\begin{array}{l}\text { Arkansas } 1 \\
\text { (P凶R) }\end{array}$ & Leak in SFP cool ing system. & 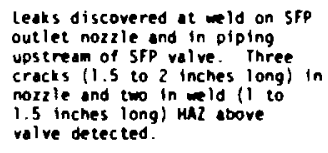 & 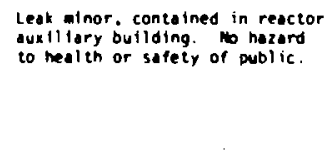 & $\begin{array}{l}\text { (Uminown) probable cause } \\
\text { is scC (fidiure mode as in } \\
50.313 / 44-118 \text { ) }\end{array}$ & $\begin{array}{l}\text { Outlet nozzle replaced. } \\
\text { ten inch scherule } 10 \\
\text { piping replaced with } \\
6-\text { inch setion bet } \\
\text { eloon and SFP value. }\end{array}$ & 50313.640 \\
\hline $6-27-96$ & $\underset{\substack{\text { Colvert cliffs } \\
\langle\text { PWR }}}{ }$ & Leak in pump valve. & $\begin{array}{l}\text { Pinhole leek wos discovered in } \\
\text { bonnet of tll boric actd dump } \\
\text { suction relief volve. }\end{array}$ & $\begin{array}{l}\text {-11 boric ac id storage tank was } \\
\text { isolated and dra ined. }\end{array}$ & $\begin{array}{l}\text { Corbon steel components not } \\
\text { comout ible with hot boric acid } \\
\text { solutions. }\end{array}$ & $\begin{array}{l}\text { Corbon steel bonnet and } \\
\text { spring replaced with } \\
\text { stainless steel equir. } \\
\text { olents. }\end{array}$ & 50317.654 \\
\hline $4-22-76$ & $\begin{array}{l}\text { MIlly stone } \\
(B W R)\end{array}$ & Leak in pipe. & 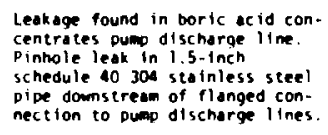 & $\begin{array}{l}\text { Minimal leakage conta ined to } \\
\text { radmaste system. }\end{array}$ & 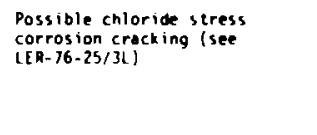 & $\begin{array}{l}\text { Leak repaired with elded } \\
\text { Deich. }\end{array}$ & $50336-450$ \\
\hline $11-6.75$ & 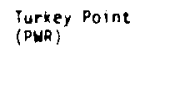 & SFP leak. & $\begin{array}{l}\text { Unit ad SFP and concrete wall } \\
\text { leakage. }\end{array}$ & $\begin{array}{l}\text { Leak rate of } 2 \text { gon. } \\
\text { channeled to rodusiste system. }\end{array}$ & Crock in liner. & $\begin{array}{l}\text { Special ss dra in trough } \\
\text { utilized to divert the } \\
\text { leskgeg to the waste } \\
\text { nolding tank. }\end{array}$ & $50251-419$ \\
\hline
\end{tabular}




\begin{tabular}{|c|c|c|c|c|c|c|c|}
\hline $\begin{array}{l}\text { Oate of } \\
\text { Event }\end{array}$ & $\begin{array}{l}\begin{array}{c}\text { Reactor } \\
\text { (1ypet) }\end{array} \\
\text { (1) }\end{array}$ & Occurrence & Description & Consequence & 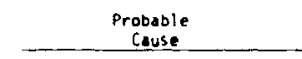 & $\begin{array}{c}\text { Corrective } \\
\text { Action }\end{array}$ & $\begin{array}{l}\text { Reference } \\
\text { pocket to. }\end{array}$ \\
\hline $8-18-75$ & 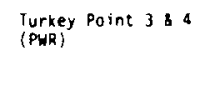 & $\begin{array}{l}\text { Mal funct ion of SFP cooling } \\
\text { pumps. }\end{array}$ & 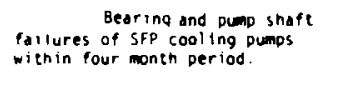 & 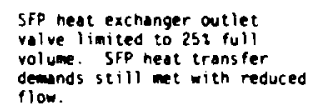 & $\begin{array}{l}\text { Excessive in ternol pumpo } \\
\text { stresses coused by fluid } \\
\text { covitiotion. }\end{array}$ & $\begin{array}{l}\text { Arter each event, oums } \\
\text { repat red. Elested and } \\
\text { re instated. }\end{array}$ & $50250-394$ \\
\hline $4-13-75$ & $\begin{array}{l}\text { Turkey Point } \\
(P \forall R) \text { P }\end{array}$ & SFP water spill. & $\begin{array}{l}\text { Emergency sffp pums oischarge } \\
\text { nose connection separated from } \\
\text { piping. }\end{array}$ & 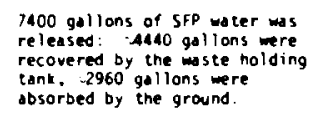 & $\begin{array}{l}\text { Hose connection not strong } \\
\text { enough to withstand pressure. }\end{array}$ & 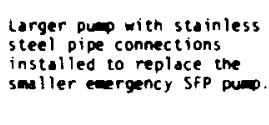 & $50251-356$ \\
\hline $3-6-75$ & $\begin{array}{l}\text { Iurkey point } \\
\text { (PAR }) \text { P }\end{array}$ & Broken restroint springs. & 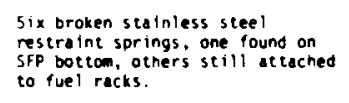 & mone, pool was aroined. & Under invest t igat ton & Springs replaced. & 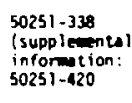 \\
\hline $17-18-74$ & 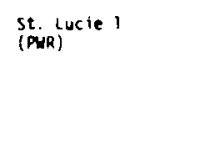 & Crack in concrete. & 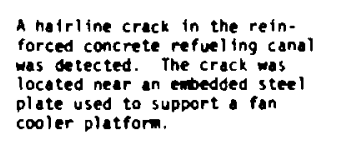 & not given & 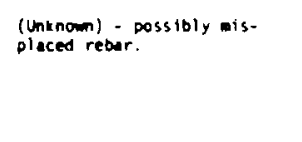 & $\begin{array}{l}\text { Cractired concrete } \\
\text { repat ired. }\end{array}$ & $50335-162$ \\
\hline $10-26-74$ & $\begin{array}{l}\text { Turkey Point } \\
\text { (Prek) }\end{array}$ & Loak in SFP liner. & Leakage detecteded in is SFP $11 \mathrm{mor}$. & 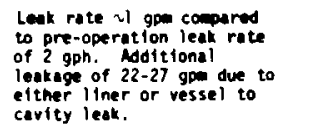 & 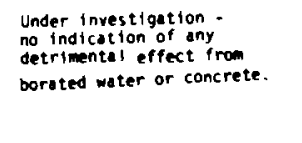 & 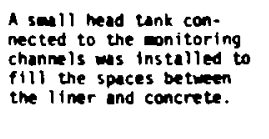 & $50250-324$ \\
\hline $8-2-74$ & $\underset{\text { Surry }}{\text { SPMR }} 1$ & SFP water spi111. & 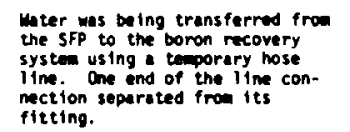 & 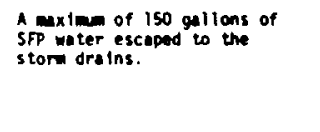 & 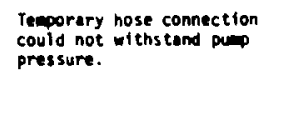 & 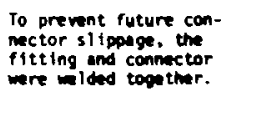 & $50280-24 / 230$ \\
\hline
\end{tabular}




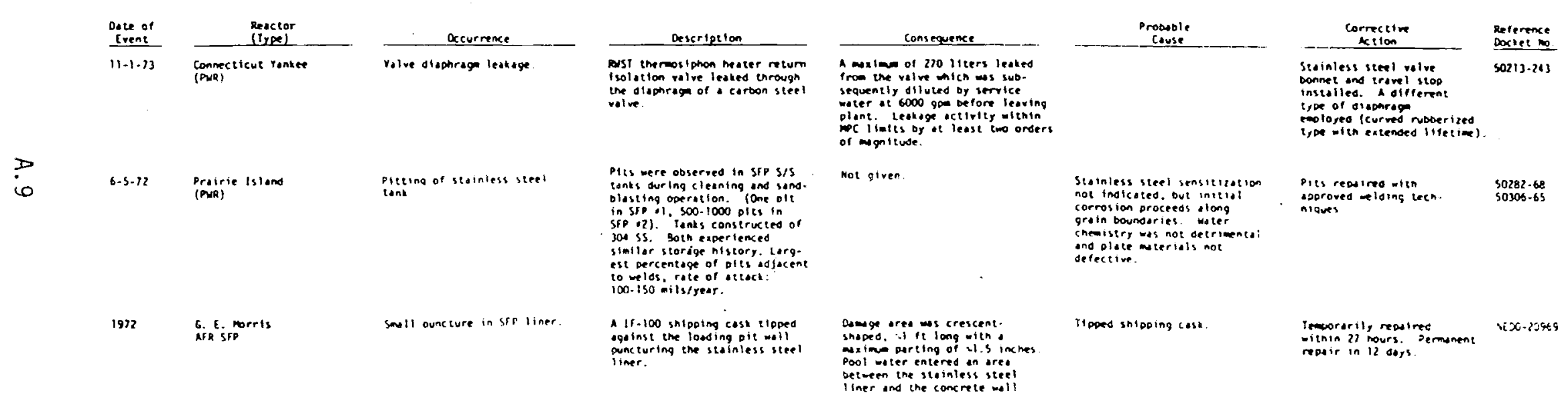


APPENDIX B

FABRICATION PARAMETERS FOR STAINLESS STEEL SPENT FUEL POOL COMPONENTS 


\section{APPENDIX B}

\section{FABRICATION PARAMETERS FOR STAINLESS STEEL SPENT FUEL POOL COMPONENTS}

Use of Type 304 stainless steel (SS) in spent fuel storage module fabrication is in accordance with ASTM SA-240 specifications. These specifications include a minimum tensile strength of $515 \mathrm{MPa}$ (75 ksi), a minimum yield strength of $205 \mathrm{MPa}(30 \mathrm{ksi})$, a maximum Brinell hardness number of 183 (or Rockwell B number of 88 ), and a $40 \%$ minimum elongation of $50 \mathrm{~mm}$ (2 in.) for the stainless steel. The material must also conform to chemical composition requirements in the specifications; these requirements are specified in Table B.1.

TABLE B.1. Chemical Requirements for Type 304 Stainless Steel

\begin{tabular}{|c|c|}
\hline Element & Composition, $\%$ \\
\hline Carbon (a) & 0.08 \\
\hline Phosphorus (a) & 0.045 \\
\hline Silicon $(a)$ & 1.00 \\
\hline Nickel & 8.00 to 10.50 \\
\hline Manganese ${ }^{(a)}$ & 2.00 \\
\hline Sulfur ${ }^{(a)}$ & 0.03 \\
\hline Chromium & 18.00 to 20.00 \\
\hline Others & $0.010^{(a)}$ \\
\hline
\end{tabular}

(a) Maximum.

The steel shall be heat treated to meet the mechanical property requirements of the specifications (above) and shall be of uniform quality. Grinding to remove surface imperfections is allowed for material with a No. 1 finish, provided such grinding does not reduce the thickness or width at any point beyond the permissible variations in dimensions. 
To further increase the corrosion resistance of 304 SS, the following additions and modifications have been suggested by Brooks and Perkins:

- The maximum carbon content in the steel shall be $0.055 \%$ instead of $0.08 \%$.

- The delta ferrite content number (an empirical number based on chromium and nickel equivalents that determines the percentage of delta ferrite in the material) for the steel shall be restricted to between 4 and 8 .

- Additional care shall be taken during any welding operations; the tungsten inert gas (TIG) fusion process for welding shall be used; and the heat input during welding shall be limited to $15,000 \mathrm{~J}$ (less than half the current nuclear industry's recognized limit).

- A melting practice shall be followed in which the residual aluminum and calcium used for the melt deoxidation shall be analyzed so that the total percentage of aluminum and calcium in the melt shall not exceed $0.01 \%$. 
APPENDIX C

WELDING THERMAL ANALYSIS 
Welding parameters from Reference 1, recommended settings for shielded metal arc welding (covered electrode) on 1/4-in. 304 stainless steel (SS) plate:

$\begin{array}{ll}\text { I, welding current } & 160 \mathrm{amps} \\ \mathrm{ts}, \text { travel speed } & 5.5 \mathrm{imp}(2.3 \mathrm{~mm} / \mathrm{s}) \\ \text { deposited weld metal } & 0.262 \mathrm{lb} / \mathrm{ft} \\ \mathrm{v}, \text { assumed voltage } & 20 \mathrm{~V} \\ \mathrm{f}, \text { heat input arc efficiency } & 0.8 \text { to } 1.0\end{array}$

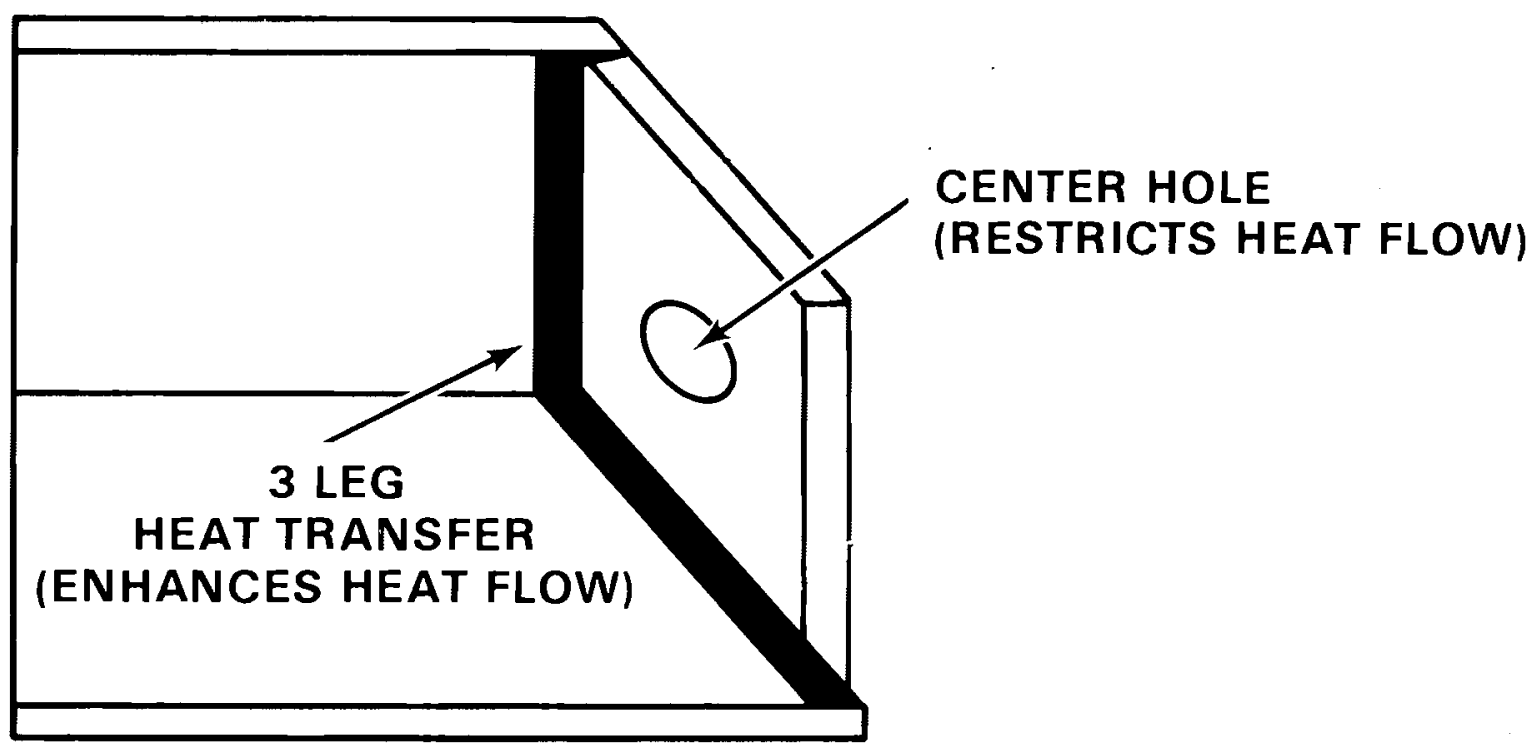

FIGURE C.1. Design Schematic of Heat Transfer Model

Application of above parameters in heat transfer equation allows for calculation of net heat input $\left(H_{n e t}\right)$ :

$$
\text { 3-leg, T-joint: } H_{\text {net }}=\frac{2 \mathrm{fVI}}{3 \mathrm{ts}}=835.2 \mathrm{~J} / \mathrm{mm}
$$




\section{Peak Temperature Calculation}

- Single pass, full-penetration butt weld in sheet or plate. Peak temperature distribution in base metal adjacent to weld given by:

$$
\frac{1}{T_{\rho}-T_{0}}=\frac{4.13 \rho C \rho t Y}{H_{N E T}}+\frac{1}{T_{m_{\rho}}-T_{0}}
$$

where $T_{\rho}=$ peak temperature at distance $Y$ from weld fusion line

$\mathrm{T}_{0}=$ initial preweld temperature of plate

$0=$ material density

$C_{p}=$ material specific heat

$Y=$ distance from weld fusion line

$\mathrm{T}_{\mathrm{m}_{\rho}}=$ material melting temperature

$\mathrm{t}=$ plate thickness.

- sample calculation, at $Y=1.5 \mathrm{~mm}$ :

$$
\begin{aligned}
& \frac{1}{T_{\rho}-20^{\circ} \mathrm{C}}=\frac{4.13\left(7.9 \times 10^{-3} \mathrm{~g} / \mathrm{mm}^{3}\right)(0.38 \mathrm{~J} / \mathrm{g}-\mathrm{K})(6.4 \mathrm{~mm})(1.5 \mathrm{~mm})}{835.2 \mathrm{~J} / \mathrm{mm}}+\frac{1}{1410-20^{\circ} \mathrm{C}} \\
& \mathrm{T}_{\rho}=1179^{\circ} \mathrm{C}
\end{aligned}
$$

Cooling Rate Calculation

- Two-dimensional, assuming no radiative or convective heat transfer.

- Check for applicability of thin or thick plate cooling rate equation:

$$
\tau=t\left(\frac{\rho C_{\rho} T_{\text {int }}-T_{0}}{H_{N E T}}\right)^{1 / 2}
$$

where $T=$ dimensionless parameter

$$
\mathrm{T}_{\text {int }}=\text { temperature of interest. }
$$


If $\gamma>0.9$, use thick plate cooling rate equation: (heat transfer through plate thickness)

$$
\frac{d T}{d t}=\frac{2 \pi k\left(T_{\text {int }}-T_{0}\right)^{2}}{H_{N E T}}
$$

If $\gamma<0.6$, use thin plate equation: (surface opposite weld at approximately same temperature as welded surface)

$$
\frac{d T}{d t}=2 \pi k_{\rho} C_{\rho}\left(\frac{t}{H_{N E T}}\right)^{2}\left(T_{\text {int }}-T_{0}\right)^{3}
$$

where $k=$ material thermal conductivity transition behavior for $0.9>\tau>0.6$.

- For specific case of 3-leg heat transfer (7-joint):

$\tau=0.24$; use of thin plate cooling rate equation is warranted.

Sample Calculations

- Width of zone experiencing temperatures (peak $\geq 600^{\circ} \mathrm{C}$ (lower sensitization temperature for austenitic stainless steels)

$$
\frac{1}{600-20^{\circ} \mathrm{C}}=\frac{4.13\left(7.9 \times 10^{-3} \mathrm{~g} / \mathrm{mm}^{3}\right)(0.38 \mathrm{~J} / \mathrm{g}-\mathrm{K})(6.4 \mathrm{~mm}) \mathrm{Y}}{835.2 \mathrm{~J} / \mathrm{mm}}+\frac{1}{1410-20^{\circ} \mathrm{C}}
$$

where $Y=10.6 \mathrm{~mm}$ from weld fusion 1 ine.

- Cooling rate at temperature (peak) of $600^{\circ} \mathrm{C}$ of weld metal or at a distance of $10.6 \mathrm{~mm}$ from weld fusion line.

$$
\begin{aligned}
\frac{\mathrm{dT}}{\mathrm{dt}}= & 2 \pi\left(0.023 \mathrm{~J} / \mathrm{mmg}^{\circ}{ }^{\circ} \mathrm{C}\right)\left(7.9 \times 10^{-3} \mathrm{~g} / \mathrm{mm}^{3}\right)(0.42 \mathrm{~J} / \mathrm{g}-\mathrm{K})\left(\frac{6.4 \mathrm{~mm}}{835.2 \mathrm{~J} / \mathrm{mm}}\right)^{2} \\
& \times\left(600-20^{\circ} \mathrm{C}\right)^{3}
\end{aligned}
$$




$$
\frac{d T}{d t}=5.5^{\circ} \mathrm{C} / \mathrm{s}
$$

\section{ASSUMPTIONS}

The following assumptions $(2-4)$ were made in this preliminary thermal analysis:

- a point heat source moving in a straight line at a constant travel speed

- peak temperatures and cooling rates equations for thin plate materials, restricting heat transfer to two dimensions (in the plane of the plate)

- no radiative or convective heat transfer effects

- cooling rates maximum at the weld centerline, but cooling rate distribution curve is such that centerline cooling rates are only 5 to $10 \%$ higher than actual weld heat-affected zone values; therefore, these rates assumed to be representative values for the immediate heat-affected zone.

- welding parameters taken from Reference 1 and apply to a covered electrode shielded metal arc welding process (manual technique) for 1/4-in. 304 SS plate.

- geometry of welded joint allows the assumption of a T-joint weld configuration on flat plates until heat transfer effects from the center hole and the other flange of the stainless steel angle take effect; center hole tends to restrict heat flow while the opposite flange promotes heat transfer; these competing effects appear to contribute to deviations from normal heat flow behavior at roughly the centerline of the backing plate. 
TABLE C.1. Thermophysical Properties for Type 304 Stainless Steel

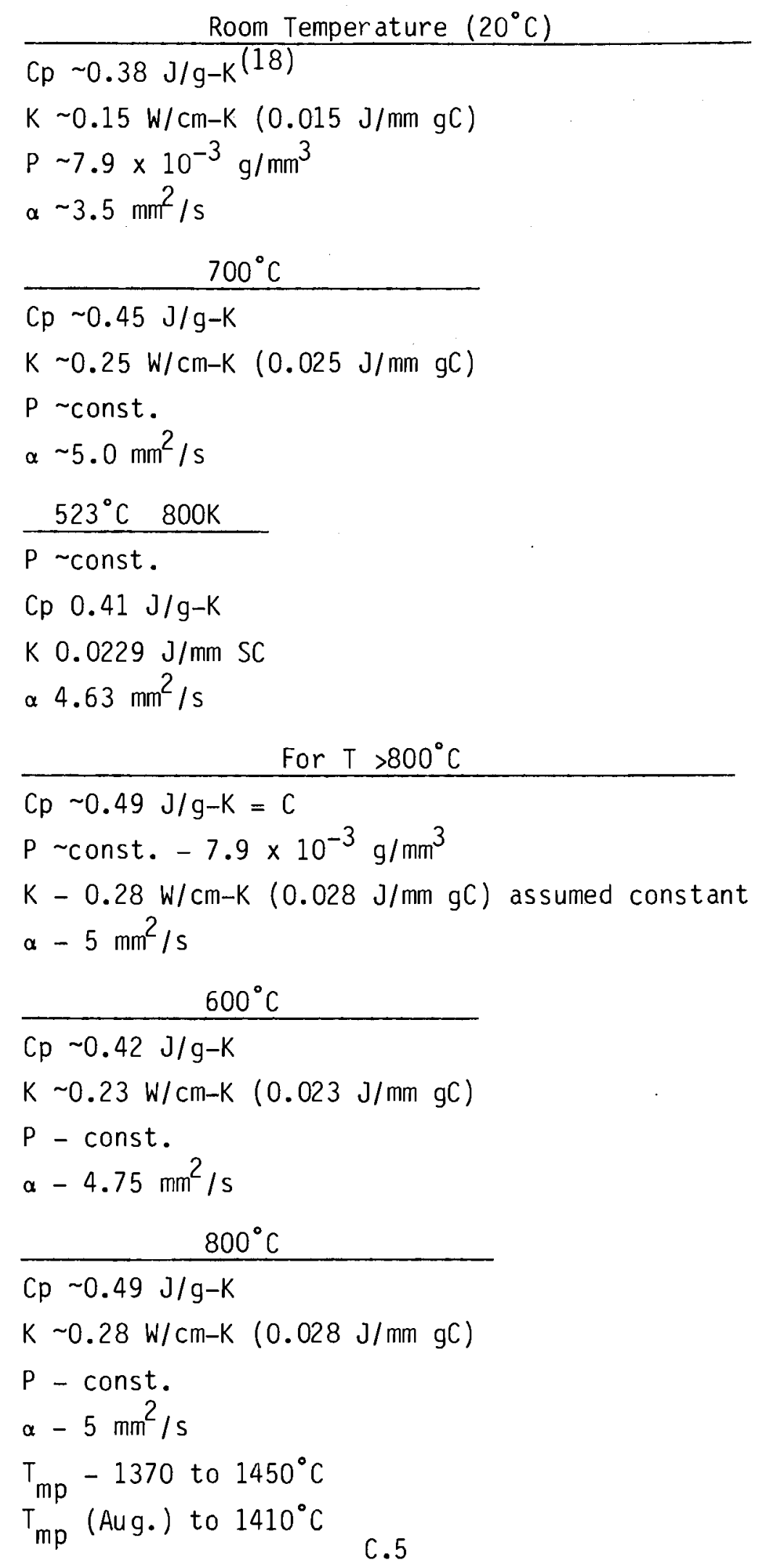




\section{REFERENCES}

1. Metals Handbook. 1971. Welding and Brazing. Vo1.6, 8th ed. ASM Publications, Metals Part, Ohio, p. 271.

2. Welding Handbook. 1976. Fundamentals of Welding. Vol. 1, 7 th ed. American Welding Society, p. 80-98.

3. Jhaveri, P., W. G. Moffatt, and C. M. Adams, Jr. January 1962. "The Effect of Plate Thickness and Radiation on Heat Flow in Welding and Cutting." Welding Research Supplement, p. 125-165.

4. Adams, C. M., Jr. May 1958. "Cooling Rates and Peak Temperatures in Fusion Welding." Welding Research Supplement, p. 2105-2155. 


\section{DISTRIBUTION}

No. of

Copies

OFFSITE

A. A. Churm

DOE Patent Division

9800 S. Cass Avenue

Argonne, IL 60439

DOE Office of Nuclear Waste Management

ATTN: M. J. Lawrence, Director

Division of Spent Fuel Storage and Transfer

Washington, DC 20545

DOE Office of Safeguards and Security

ATTN: Dr. Samuel C. T. McDowell

Assistant Director for Research and Development

MS A2 1016

Washington, DC 20545

DOE Division of Waste Management

ATTN: Director

Washington, DC 20545

DOE Albuquerque Operations

Office

ATTN: Manager

P.0. Box 5400

Albuquerque, NM 87115

DOE Chicago Operations Office

ATTN: Manager

9800 S. Cass Avenue

Argonne, IL 60439
No. of

Copies

DOE Columbus Program Office

Richland Operations office

ATTN: J. L. Neff, Program Manager

$505 \mathrm{King}$ Avenue

Columbus, $\mathrm{OH} 45201$

DOE Idaho Operations Office

ATTN: J. P. Hamric, Director

Nuclear Fuel Cycle Division

550 Second Street

Idaho Falls, ID 83401

DOE Nevada Operations Office

ATTN: Manager

P.0. Box 14100

Las Vegas, NV 89114

DOE Oak Ridge Operations Office

ATTN: S. Ahrends, Director

Reactor Division

P.0. Box E

Oak Ridge, TN 37830

DOE Rocky Flats Area Office

ATTN: Area Manager

P.0. Box 298

Golden, C0 80401

DOE San Francisco Operations Office

ATTN: Director, Nuclear Energy Division

1333 Broadway

Oakland, CA 94612

DOE Savannah River Operations Office

ATTN: Manager

P.0. Box $A$

Aiken, SC 29801 
No. of

Copies

DOE Savannah River Operations Office

ATTN: Director, Spent Fuel Project Office P.0. Box A

Aiken, SC 29801

27 DOE Technical Information Center

Allied-General Nuclear Services

ATTN: M. Grooms

Library Services

P.0. Box 84

Barnwe 11, SC 29812

Argonne National Laboratory

ATTN: Dr. M. J. Steindler, Associate Division Director Chemical Engineering Division Bldg. 205

9700 S. Cass Avenue

Argonne, IL 60439

Atomics Industrial Forum

ATTN: E. Gordon

7101 Wiscons in Ave., 12th Floor

Washington, DC 20014

Babcock \& Wilcox Co.

Lynchburg Research Center

ATTN: M. N. Baldwin

P.0. Box 12600

Lynchburg, VA 24505

Battelle Columbus Laboratories

ATTN: Manager, ONWI

505 King Avenue

Columbus, $\mathrm{OH} 43229$

Battelle Memorial Institute

ATTN: Dr. J. Beavers

505 King Avenue

Columbus, $\mathrm{OH} 43201$
No. of

Copies

Boeing Engineering and Construction Company

ATTN: S. M. Graves, Program Manager

Mailstop $9 A-48$

P.0. Box 3707

Seattle, WA 98124

Brookhaven National Laboratory

ATTN: Dr. W. A. Higinbotham

Technical Support Organization

Upton, NY 11973

EG\&G Idaho, Inc.

ATTN: Dr. D. D. Keiser, Manager

Fuels and Materials Division

P.0. Box 1625

Idaho Falls, ID 83401

Edison Electric Institute

ATTN: L. E. Mills

1111 19th Street, N.W.

Washington, DC 20036

Electric Power Research Institute

ATTN: P. F. Williams

Technical Library

P.0. Box 10412

Palo Alto, CA 94304

Environmental Research Laboratories

National Oceanic and Atmospher ic Administration

ATTN: J. L. Heffter

U.S. Department of Commerce

8060 13th Street

Silver Spring, MD 20910

Exxon Nuclear Corporation

Process Development \& Support Section

Idaho Chemical Programs

550 Second Street

Idaho Falls, ID 83401

General Atomic Company

ATTN: J. Shefcik

P.0. Box 81608

San Diego, CA 92138 
General Electric Uranium Management Corporation

ATTN: B. F. Judson, Vice President and Manager

GEUMCO-Engineering

175 Curtner Avenue (Mail Code 858)

San Jose, CA 95125

Kaman Sciences Corporation

ATTN: N. J. Becar

P.0. Box 7463

Colorado Springs, CO 80933

Lawrence Livermore Laboratory

ATTN: F. R. Wondolowski

P.0. Box 808

Livermore, CA 94550

Los Alamos Scientific Laboratory

ATTN: Dr. D. F. Bowersox, MS-328

Plutonium Chemistry and Metallurgy Group CMB-11

University of California

Los Alamos, NM 87544

Management Analysis Company

ATTN: J. Norr is

11100 Roselle Street

San Diego, CA 92121

Monsanto Research Corporation

ATTN: Library

Mound Laboratory

P.0. Box 32

Miamisburg, OH 45342

NL Industries, Inc.

ATTN: George L. Stukenbroeker

1130 Central Avenue

Albany, NY

Nuclear Assurance Corporation

ATTN: J. Fox

24 Executive Park West

At lanta, GA 30329
Nuclear Energy Service, Inc.

ATTN: William J. Marrion

NES Division

Shelter Rock Road

Danbury, CT 06810

Nuclear Services Corporation

ATTN: Dr. M. Reier

1700 Dell Avenue

Campbe11, CA 95008

Oak Ridge National Laboratory

ATTN: B. L. Vondra, Jr.

Union Carbide Corporation

Building 7601

P.0. Box $X$

Oak Ridge, TN 37830

Resource Planning Associates, Inc.

ATTN: Alva Collins

1901 L. Street, N.W.

Washington, DC 20036

Ridihalgh, Eggers, and Associates

ATTN: $P$. E. Eggers

2112 Iuka Avenue

Columbus, $\mathrm{OH} 43201$

Rockwell International

ATTN: L. L. Richey, Program Manager

Waste Conversion and Fixation

P.0. Box 464

Golden, C0 80401

Sandia Laboratories

ATTN: J. P. Hohimer

Division 5216

Albuquerque, NM 87185

Savannah River Ecology Lab

ATTN: Director

Headquarters

Washington, DC 20545

E. I. du Pont de Nemours and Co.

ATTN: Don Turno

Savannah River Laboratory

Technical Info. Svc. 773A

Aiken, SC 29801 
No. of

Copies

Science Applications, Inc.

ATTN: Dr. E. A. Straker

1200 Prospect Street

La Jolla, CA 92038

College of Engineering

ATTN: A. Hill

University of South Carolina

Columbia, SC 29208

George P. Wagner

Station Nuclear Engineering Dept.

P.0. Box 767

Chicago, IL 60690

S. M. Stoller Corporation

ATTN: W. A. Franks

1250 Broadway

New York, NY 10001

Tennessee Valley Author ity

ATTN: Robert Davidson

403 Power Bldg.

6th and Market Street

Chattanooga, TN 37402

Union Carbide Corporation

Nuclear Division

ORGDP Records Department

P.0. Box $P$

Oak Ridge, TN 37830

U.S. Nuclear Regulatory Commission

ATTN: Group Leader for Spent

Fuel Storage Installation

Division of Fuel Cycle and Material Safety

Washington, DC 20545

U.S. Nuclear Regulatory Commission

ATTN: Director

Division of Inspection and

Enf or cement

101 Marietta Street

Suite 3100

At lanta, GA 30303
No. of

Copies

R. A. Newton

Wiscons in Electric Power Company

Room 381

231 W. Michigan

Milwaukee, WI 53021

ONSITE

4 DOE Richland Operations Office

E. A. Bracken

H. E. Ransom

J. J. Schreiber

Technical Information

13 Rockwell Hanford Operations

H. Babad

A. E. Barker

L. C. Brown

R. A. Deju

R. J. Gimera

D. R. Gustavson

E. J. Kosiancic

C. M. Manry

I. E. Reep

J. H. Roecker

R. E. Smith

D. D. Wodrich

File Copy

Exxon

S. J. Beard

UNC/United Nuclear Industries

T. E. Dabrowski

3 West inghouse Hanford Company

A. G. Blasewitz

D. A. Cantley

R. E. Lerch 
No. of

Copies

87 Pacific Northwest Laboratory

R. P. Allen

W. J. Bailey

N. E. Ballou

S. 0. Bates

A. Brandstetter

R. L. Brodzinski

L. L. Burger

D. B. Cear lock

T. D. Chikalla

M. 0 . Cloninger

R. L. Dillon

P. G. Doctor

H. Drucker

S. K. Edler

C. E. Elderkin

J. R. Eliason

R. K. Farnsworth

J. W. Finnigan

J. A. Franz

J. J. Fuquay

G. W. Gee

R. W. Goles

C. R. Hann

A. J. Haverfield/W. R. Wiley

O. F. Hill

E. R. Irish

J. H. Jarrett

A. B. Johnson, Jr. (25)

R. S. Kemper
No. of

Copies

M. R. Kreiter

L. T. Lakey

T. M. Lambright

J. M. Latkovich

R. C. Liikala

R. P. Marshall

J. L. McElroy

C. L. Mohr

R. D. Nelson

J. M. Nielsen/R. W. Perkins

R. E. Nightingale

D. E. Olesen

B. E. Opitz

J. M. Perez, Jr.

A. M. Platt

J. V. Robinson

R. E. Schreiber

A. M. Sutey

G. L. Tingey

C. M. Unruh

H. H. Van Tuyl

J. W. Voss

R. E. Westerman

E. J. Whee lwr ight

M. K. White

L. D. Williams

W. K. Winegardner

Technical Information (5)

Publishing Coordination YO(2) 


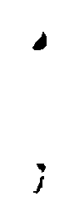

$t$ 